
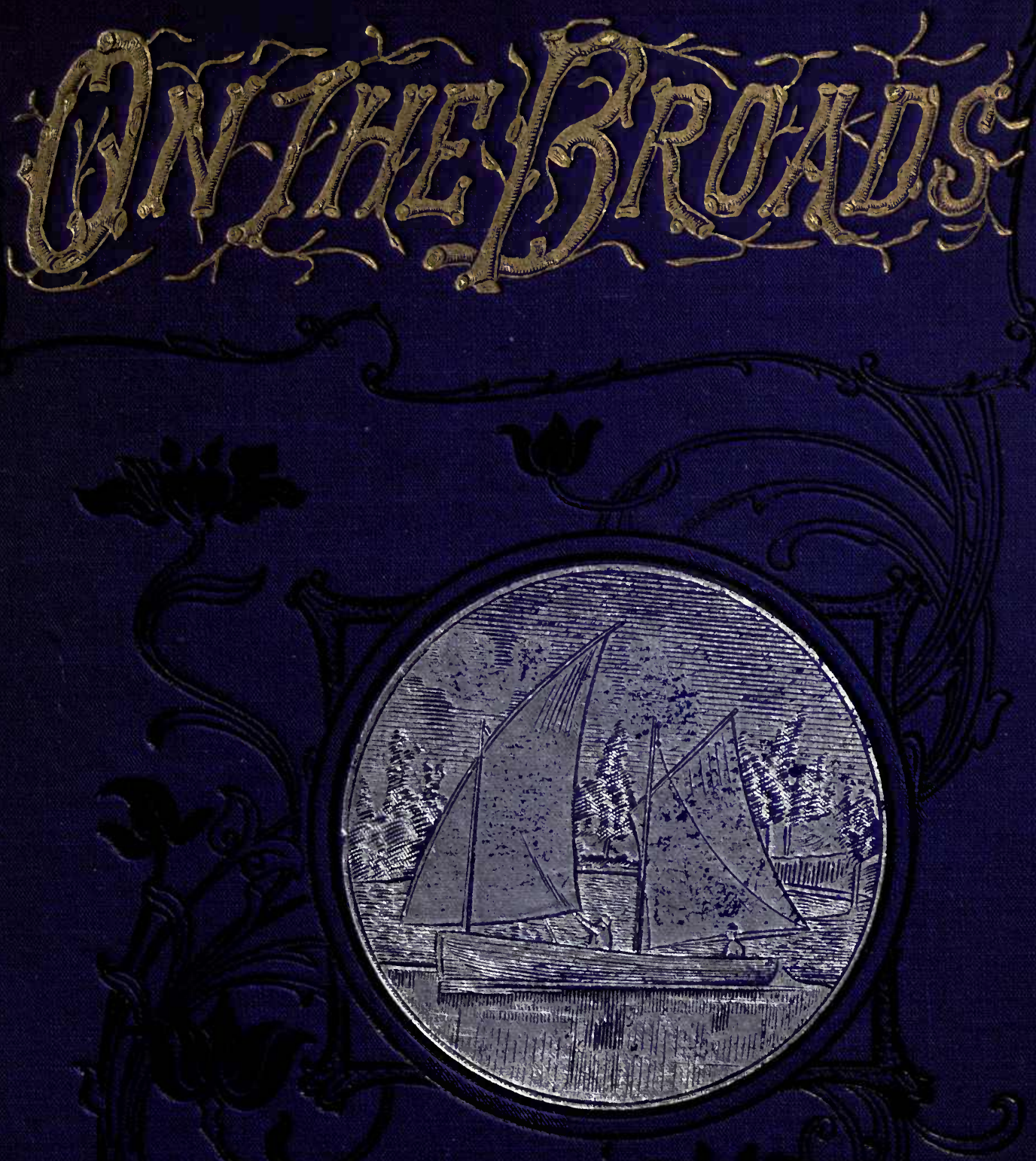


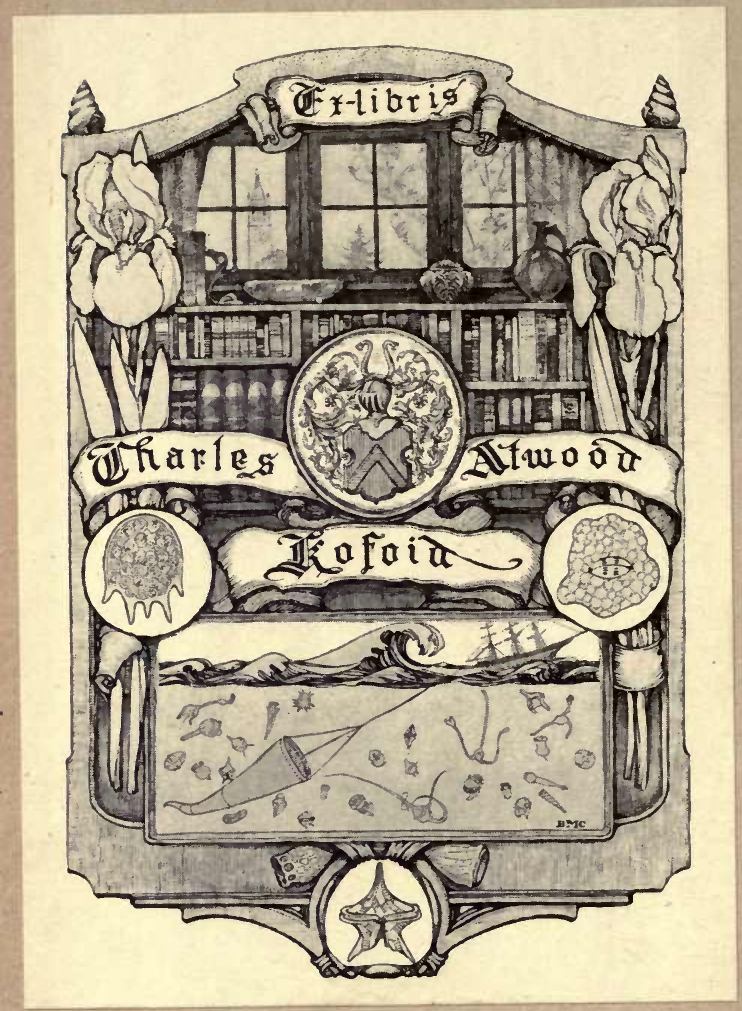




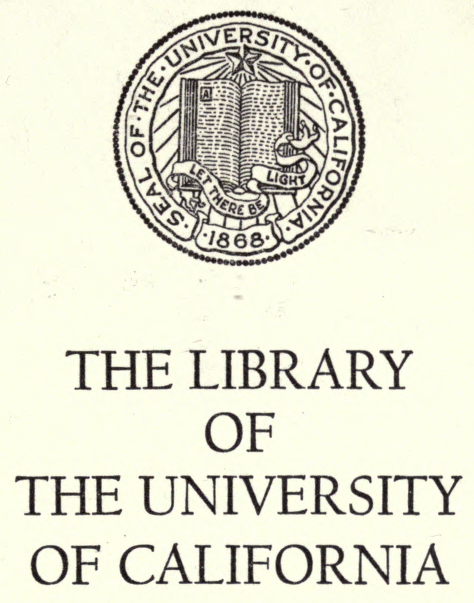

\author{
PRESENTED BY
}

PROF.CHARLES A. KOFOID AND MRS. PRUDENCE W. KOFOID 


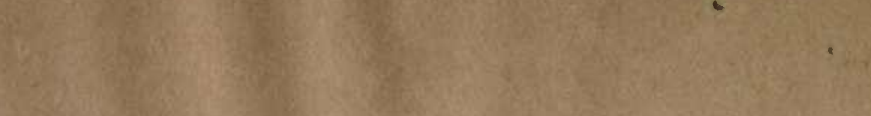

अite

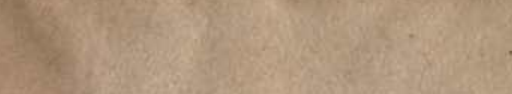

3.

p

W

at

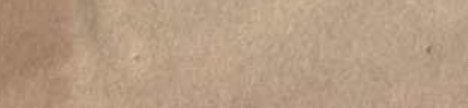

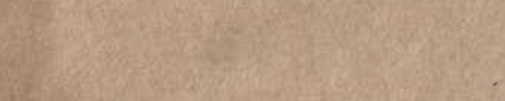

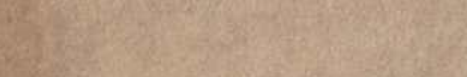

min

$x^{2}$

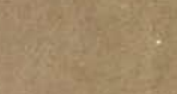





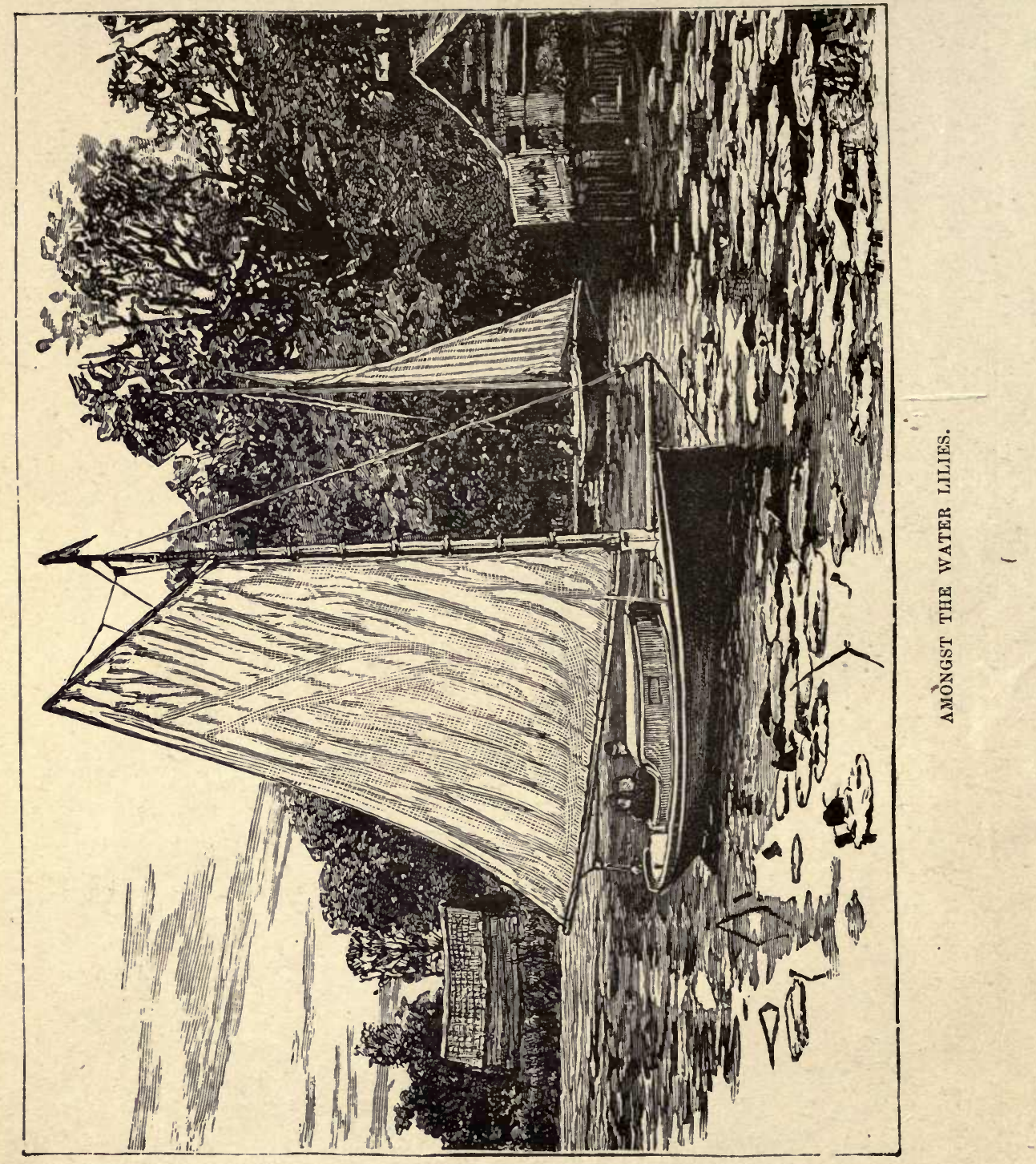




\title{
MAN AND NATURE ON \\ THE BROADS.
}

\author{
BY A. PATTERSON
}

Author of "Broadland Scribblings," \&c.

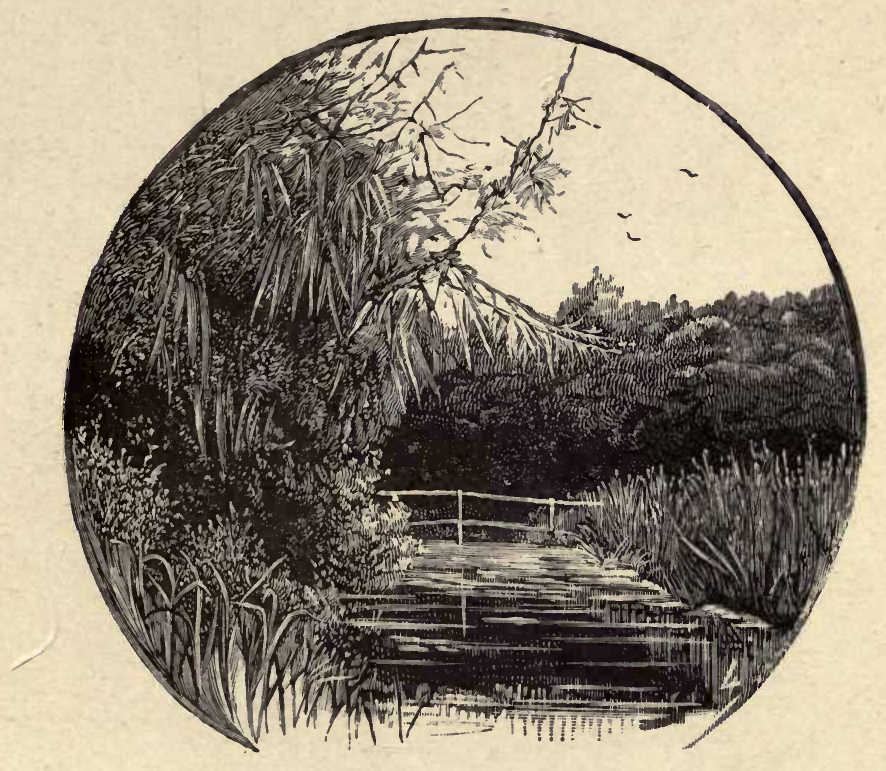

A QUIET CORNER.

Pondon:

THOMAS MITCHELL, 48-50 ALDERSGATE STREET, E.C. 

TO

Mrs. E. PHILLIPS,

OF CROYDON,

Vice-President of the Society for the Protection of Birds, AND A

Devoted Friend of the Birds,

THIS VOLUME

IS RESPECTFULLY DEDICATED. 


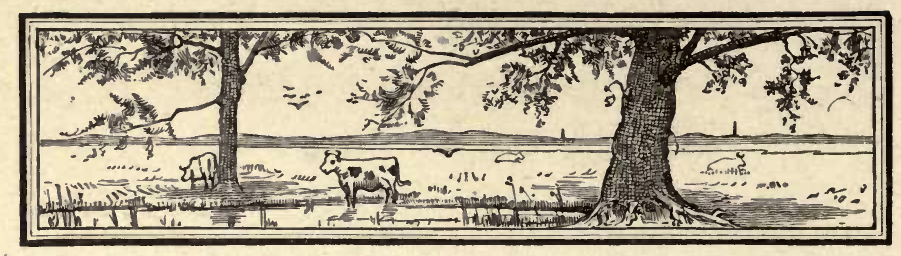

CONTENTS.

January in Broadland

February in Broadland

March in Broadland

April in Broadland

May in Broadland

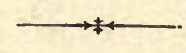

June in Broadland

July in Broadland

August in Broadland

September in Broadland

October in Broadland -

November in Broadland

December in Broadland 


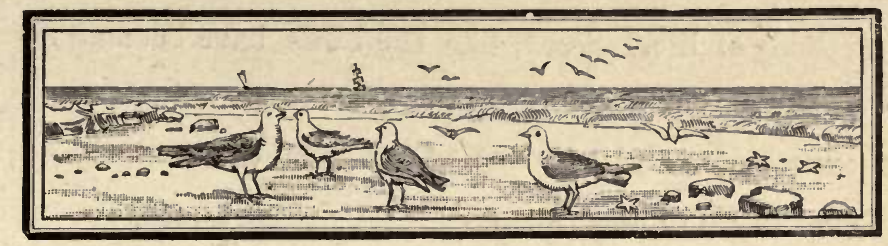

$Q+138$
$N_{6} P_{2}$

PREFACE.

EN years ago a book on Broadland would have needed a lengthy introduction-the likeness of its spreading lagoons, their whereabouts, attractions, and delights would have required treatment in detail to have become intelligible to many who live outside the county that boasts their possession. Now everyone knows them, many by a personal inspection, most by repute. In summer crowds of yachting folk, and excursionists by rail, steamer, and road, visit these reed-surrounded, coot-haunted waters. But to know them thoroughly is to visit them at every season of the year-a privilege beyond the means or possibilities of all save the favoured few who live ' upon the spot.'

'Man and Nature on the Broads' will undoubtedly prove interesting to both those who know them and those who would like to, and as it is the first venture which has professed to give anything like an all-the-year-round glimpse of its people and bird life and general aspects, it may be equally acceptable.

The advance of education, an altered state of agriculture, and several other causes operating - such as will be further commented upon in some of the chap- 
ters-have materially altered the personnel of the inhabitants, their ways and customs, and methods of life. Some, like the birds, have become rara ares, and will probably as individuals become extinct, as some avine species have also become. The experiences and opinions of a few of these nearly obsolete characters will be found in 'Man and Nature.'

A. P.

Great Yarmouth, October, 1895.

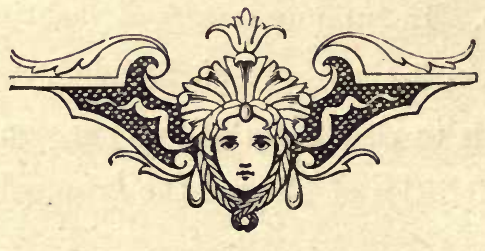




\section{MAN AND NATURE ON}

THE BROADS.
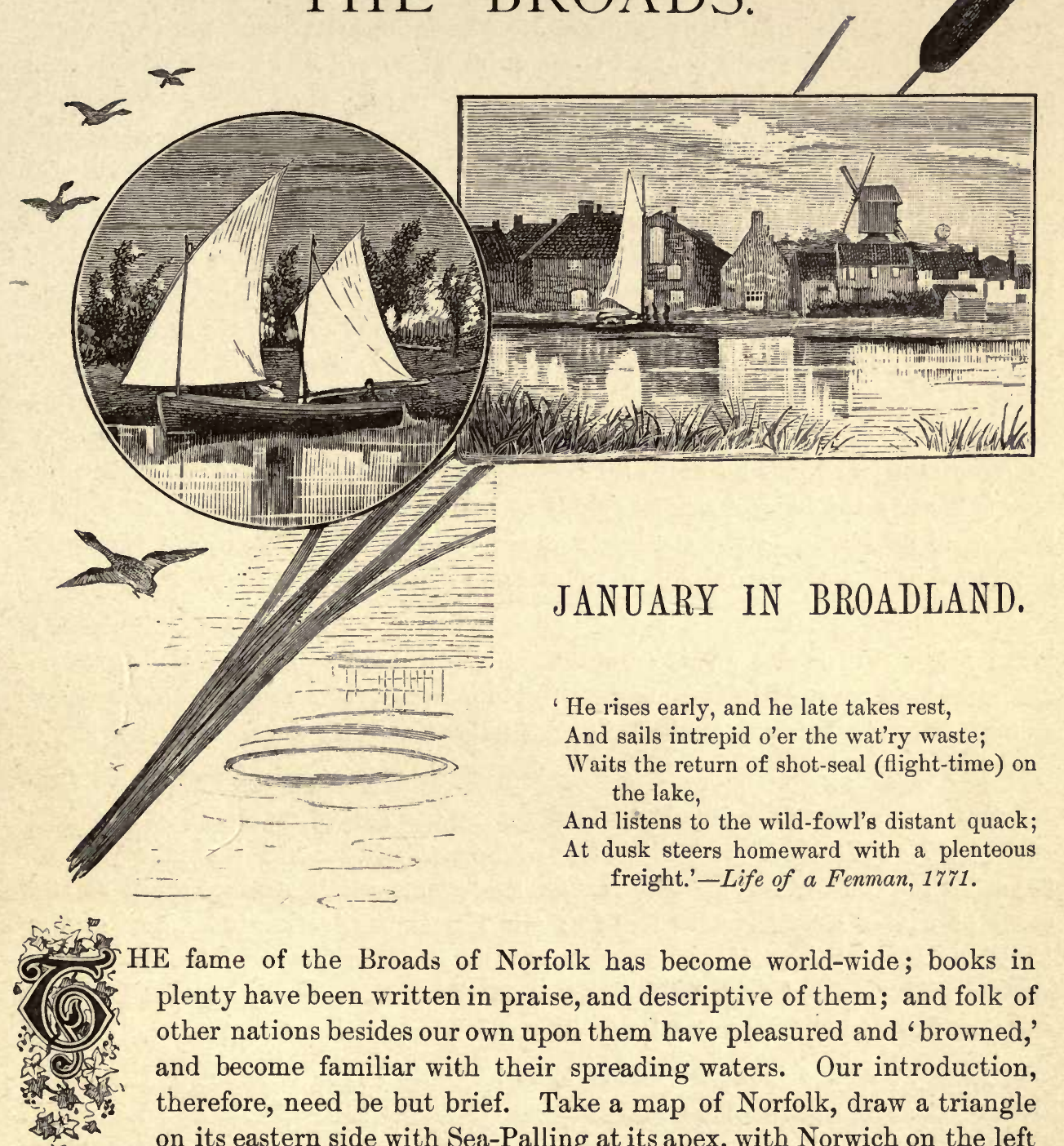

HE fame of the Broads of Norfolk has become world-wide; books in plenty have been written in praise, and descriptive of them; and folk of other nations besides our own upon them have pleasured and 'browned,' and become familiar with their spreading waters. Our introduction, therefore, need be but brief. Take a map of Norfolk, draw a triangle on its eastern side with Sea-Palling at its apex, with Norwich on the left and Yarmouth at its right, and you will include in its area of some 250 square 
miles the greater portion of these 5,000 acres of charming lagoons, and some 200 miles of navigable waterways. They have a beauty peculiarly their own, to enjoy which to the full, one must needs get under canvas and cruise here and there in the most leisurely fashion, for Broadland is not a land of worry or bustle, but one of dreams and delightful lotus-eating. He who in his trim yacht glides through the narrow channels which connect these quiet lakes, will find a certain sameness about their characteristic points which is rather refreshing than otherwise, an effect quite different from that produced by the repetition of many other scenes: and our treatment of an individual Broad will suffice for a description of them all.

Broadland offers to all its patrons something that will make their holidayjaunt pleasurable even in remembrance. The angler finds its waters teeming with hungry denizens; to the yachtsman it offers advantages unparalleled in the kingdom; the artist who loves the picturesque finds in it an el Dorado; the archæologist, the botanist, and the entomologist will find plenty to see and do; whilst the admirer of things ornithological may travel far and wide in search of a happier hunting-ground. To the strong the Broad district is exhilarating, and to the weakly health-giving; and he who wants for nothing, save perfect rest and quietude, may here idle away the longest summer's day in perfect happiness, undisturbed by the jostling of his fellows or the costliness of his well-earned holiday. The air is dry and bracing; the annual rainfall is below many other districts in the kingdom.

The Broadland native is a hardy, docile being, with a tawny, sun-scorched beard, a fair skin and a ruddy complexion, a nose that savours of the aquiline, and mild blue eyes, with Norse or Danish blood in his veins mixed with a dash of Saxon. His vocabulary is limited, but his tongue is easy-going, and 'lets fly' a strange jargon spiced with stray Danish derivatives and a host of curious accents.

Let us hie away then into Broadland, taking our first glimpse and impressions with the New Year's advent, when the cold north winds whirl the plumy snowflakes hither and thither, and the leafless reed-stems rustle strange music as the gusts of winter sway them to and fro; and the erstwhile tranquil waters of the Broad are flinging foam-tipped waves into their midst, or may be, when the merry skaters glide to and fro upon its glassy surface, and the starving coot, at his wits' end, has flown to the nearest estuary in search of needful sustenance.

To-day we have found its waters locked quietly in the embrace of the frostsprite. Snowflakes are falling and eddying around us in the keen, bustling wind. The thermometer is still descending, to the delight of many who will be shortly speeding hither from the town, to whirl with the lively throng on iron-shod feet. 
We have our skates with us, and being assured by a passing rustic that 'Yow doan't need tu fare, 'bor, for it's friz hard enuf tu bear a dicky!'-we sit down upon the stubbly broad-margin and adjust our 'skeets,' as the communicative native terms them. A few rather awkward movements, for it is long since we tried them, put us at our ease, and we launch out upon the transparent surface. At this moment an individual with a parsonical appearance glides swiftly round a reedy promontory, merrily salutes us, takes a right turn, and hies away as on wings of wind. Reassured, we strike out boldly, and are soon rapidly gliding in the direction he has taken.

How bare is the Broad-margin of vegetation! Nothing remains now of the broad-leaved water-lilies, whose snow-white petals last summer formed such a de- lightful foreground to the phalanx of emerald-green reeds, and the taller bulrushes, whose big brown 'pokers' flung their shadows over them into the limpid waters where the lilies rested. The yellow iris has left nothing but its brown broken stubble upon the once-time boggy, but now hard-frozen 'rond,' where the alders in the background point upwards their leafless twigs. See! there are several coletits busily hunting in the stunted branches in search of such larvæ or little insects as may have hidden in the bark-chinks for a winter's nap. What nimble birdacrobats they are! Now hanging topsy-turvy, now running head downwards as the humour or occasion prompts them, it is small matter to them in what position they hunt their sleeping prey. High overhead passes a harrier of some kind-he is a Hereward in bird-land!

Observe yonder tiny red-brown birdies busy among those plumy reed-tops. They are the bearded-tits, or 'reed-pheasants' of the Norfolk natives. Hardly must they fare now the aphides and the dipterous insects are dead or hybernating in more protected locations, and the tiny molluscs that crawled up the verdant rush-stems are in safe hiding in the depths below. They are glad now to glean the seeds of the withering Broad-vegetation, among whose leafy recesses they were cradled. Let us hope Jack Frost may deal gently, and that the evil eye of the skulking gunner may not glance down 'sights' at them. Many familiar birds we miss altogether; the rails and moorhens have sought the sheltered ditches; and the great crested grebes have gone south for the winter, for what good were it to stay when the little fry have sought the deepest recesses of the Broad, and the ice-bound surface forbids them diving in search of them? The coots, held back until well-nigh starved, hoping against hope for a break in the long-continued frost-they, too, have departed, but are content to pick up a scanty living in the salt waters of the tidal estuary, persecuted, alas! at every turn by the merciless 
gun of the wildfowler. The summer-birds of passage are almost forgotten; we dream not of meeting with the swallows, the reed-warblers or the cuckoo; they are happy among the insect-legions swarming by the lake-sides of a warmer continent.

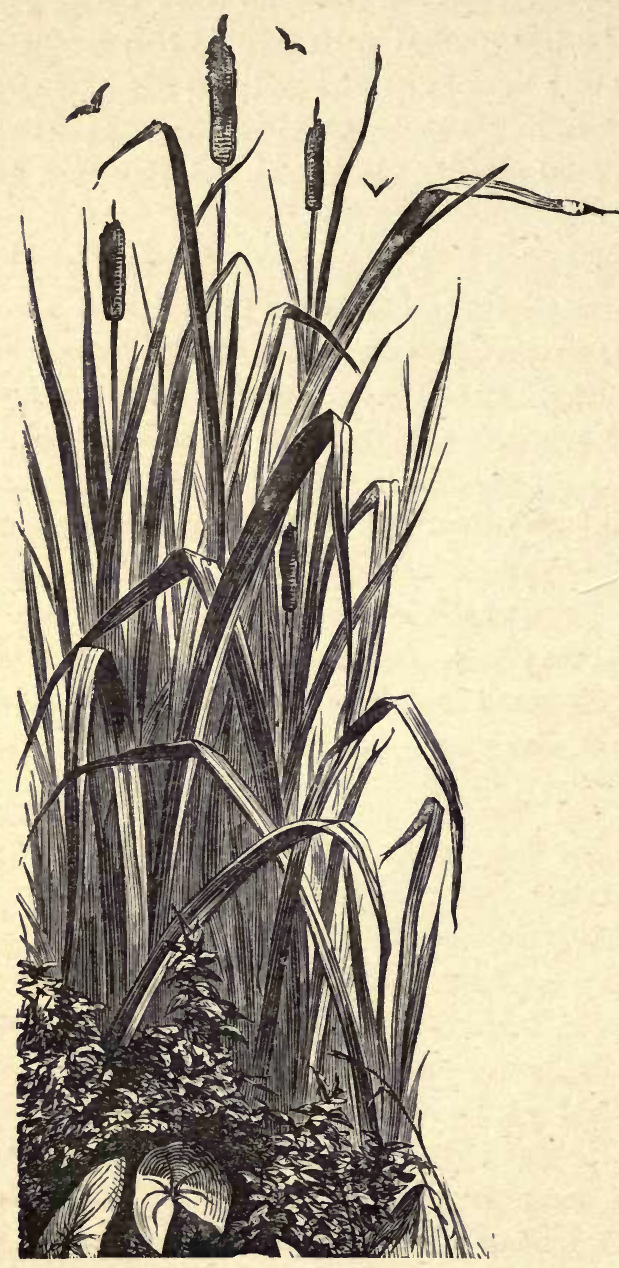

BROADLAND 'POKERS.'

The snow has ceased awhile, and the sun breaking out smiles down upon a landscape of unsullied white, which sparkles with the frost-dust crystals. Yon fenman's cottage, cosily nestled amid those stunted willows, and the quaint little pump-mill close beside it, form an interesting break in the uniformity of the Broad's surroundings. A skein of wild-geese in wedgeform passes overhead; a puff of smoke and the report of a gun tell us other eyes beside our own have observed them. But they flew far too high for the leaden messengers to reach them. The fenman's dinner to-day will be gooseless. A flock of wild ducks dash past us on noisy pinions; a squadron of melancholy rooks are fruitlessly grubbing in the distant field; and the flapping of wood-pigeons falls ever and anon upon the ear. Only one species of bird appears really contented, and that is the hooded crow; what cares he if hard times cause his fellows to perish, for does he not thrive upon the carcases of the fallen?

While dashing to and fro the time speeds merrily on, and pleasant company-for others, the parson among them, have joined us - makes it glide by imperceptibly. We tire at length, and make again for the edge of the alder 'carr,' whence we started. Meanwhile the storm-clouds have been piling up in the beavens, and snow begins again to fall heavily, ere long hiding everything but the nearest objects 
from view, and these are partially covered with the soft, pure mantle of winter.

$\circ$

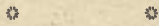
$\%$

$\circ$

$a$

*

$\circ$

It is still mid-winter and cold, but a thaw has suddenly set in. It is sloppy underfoot. Nature has assumed a gloomier outlook, and everything but the birds appears dull; they, poor rogues, are glad of a respite, for the softened earth will yield them their meat once more. The snipe has again made his appearance, and is probing in the unlocked ooze for worms and buried larvæ. The chaffinches are searching in the cultivated patch for uncovered seeds, the lapwings in the lowlands are eyeing each likely wormcast, and the meadow-pipit is closely scanning the weedy débris by the ditch-side.

We have been wending our way down from the deserted little Broadland railway station, where the solitary porter seemed loth to drag himself from the cheery fire in his cabin of an office. A redbreast jauntily chinked us 'good-day!' from an elevated position upon the great white crossing-gate, and a couple of hungry sparrows fell to fighting on the metals over a breadcrumb dropped from a carriage window; they really appear to enjoy a breakfast all the better for a preliminary scrimmage.

As we pass along between the tall hawthorn hedges, redwings reluctantly leave their feasting upon the lessening berries; now a blackbird, and now a fieldfare takes to startled flight from the rootlets below, where dormant snails were being eagerly searched for. A woodcock overtops one hedge, and disappears behind the one on the other side of the road.

Here we are again by the Broadside, according to appointment, and here is our friend the skating parson, clad from top to toe in wild-fowler's attire, and but for that intellectual face, you might for all the world take him for a fenman. He is none of your namby-pamby individuals, who portray life as a perpetual season of psalm-singing and breast-smiting; why we need remain 'miserable sinners,' he is at a loss to know, but whilst he

\section{'Lures to brighter worlds and leads the way,'}

he believes in securing all the enjoyment in the present world possible, so long as such pursuit is in accord with sound judgment and Bible truths. Forsooth! Le is a sportsman, and is well able to handle a gun and scull a punt; he is muffled up in costume suited to the season and the errand on which we are going. Our invite to join him dates back to that frosty morning's skating. His roomy punt, wherein is fastened by a ' $k$ nee' a huge gun, lies beside the puny bridge which spans a 'neck' of the Broad that communicates with another. All aboard, his 
man, a splendid specimen of the hardy fenman, pushes us off, and heedless of the bubble-crested waves churned up by the rough wind upon the dark waters of the Broad--made darker still by the clouds above-head-we are pulled across it.

A bunch of wildfowl are disporting themselves in the chilly waters, while a few of their number are preening their feathers upon the jagged ice held as at anchorage by the reed-stems. Silently and motionless we now crouch in the boat; the fenman, who has quietly glided into the stern, sculls her forward with a single oar, whilst the parson, on his elbows and knees, places his finger upon the trigger of the gun. Peering over the boat's rail, we observe that the ducks are becoming alarmed, and are gathering into a more compact body, and those that were on the ice have slid down and joined their companions. With a splash and a whirr, the startled bircs take to wing. We momentarily imagine that our host does not intend to fire at them, but we are mistaken. It is the moment he has awaitedwhen the crowding birds shall close up and rise in a body from the water. With a tremendous roar, and a recoil which throws us flat upon our face, the gun belches forth its death-dealing contents. The parson has made a bag! As the smoke clears off, and our boatman eagerly pushes us forward, several dead forms are seen floating upon the surface; a wounded bird or two are stopped short in their efforts to reach the reedy shelter by the shoulder-gun of the clerical sportsman. Nine widgeon, a couple of mallard, and a golden eye, are the result of our shot. The survivors have flown away seaward.

Whilst our man is reloading, our ecclesiastical friend, evidently much elated by his success, waxes chatty.

'It is a matter for regret,' says he, 'that the birds of Broadland have of late years become scarcer.' Our looking at the victims in the boat draws forth a curious smile on his rubicund face. 'Ah!' he added, 'you think such sharp practice as this has had something to do with the decrease of our avi-fauna; and perhaps it has; but it is not the gun altogether which has slaughtered off the birds, but the drainage of the lowlands, the cultivation of waste-places, and the consequent dearth of suitable food and shelter, or 'lay,' as the rustics term it, that have more effectually driven them away. Before steam-mills had usurped the clanking pump-mills, surplus water accumulated in the lowlands, and legions of wild-fowl swarmed the marshes. The birds fed and frolicked in comparative safety, and in positive plenty; and although great numbers were slain, they were but a small percentage of those that remained. Cattle and corn and root-crops usurp the places where the duck once swam in the puddles and the wading bird probed in the shallows. The ruff and reeve and the bittern, which in my father's time were 
numerous, are rare hereabouts to-day. The dastardly egger has done much to aggravate the situation. Where the gun has slain its units, the egger has annihilated a legion; but his day, too, is past, for he has destroyed his own ill-favoured craft. The lapwing has been fairly ousted by him. And then the privacy of some birds, in the breeding season, has been of late years intruded upon by the prying tourist, who in every case is not content with seeing but must handle.

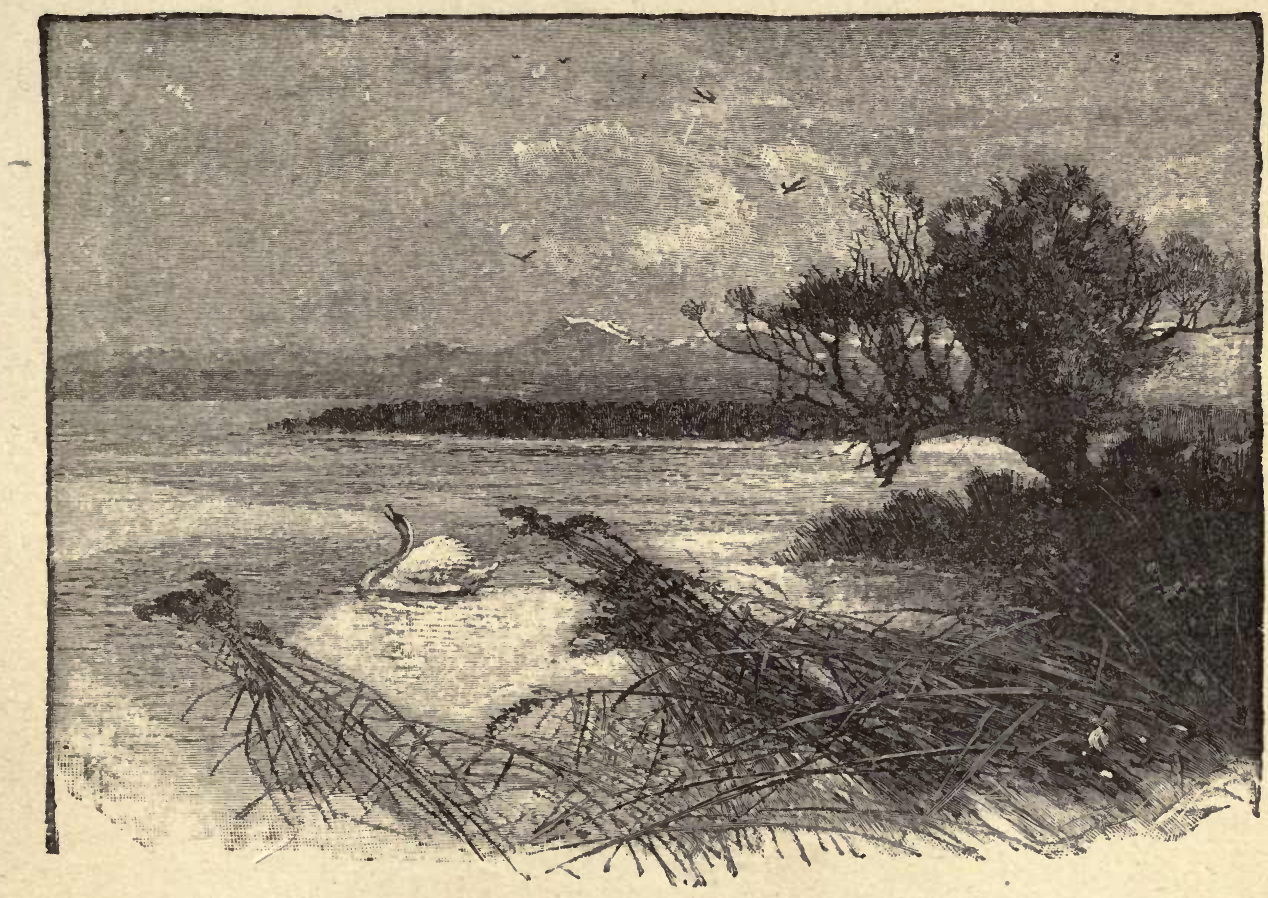

A PEEP AT THE BROADS.

'I believe, also, in transmitted instinct; we get fewer birds now, for generations of disappointment have taught the species to keep away from where they'd starve. Can I justify my action? Most decidedly. These birds which lie dead here are foreign-bred. They came, a mere sample of the hosts bred in the morasses of the north; their demise but little, if anything at all, affects the race. They are sent us as food: the Author of our being and theirs placed us in dominion over the fowls of the air as well as of the fishes of the sea. You don't blame a 
fisherman for taking the life of a herring. And why blame me? Many of my parishioners are glad of a wholesome dinner, and these will fall to their share. And it's no use hiding the fact, I love the 'sport,' cruel as I know you esteem it. And then a country parson's life is rather a monotonous affair; and anything that one can conscientiously admit to alleviate or vary it is worth the letting in. Visit my parishioners? Well! I do my share at that-but lie low!'

A parcel of swans wheeling aloft has caught his keen, quick eye, and we ' lie low' to make ready a warm welcome for them. But their eyes are sharper than our own, and they fly away to a safer neighbourhood.

Space forbids our entering into all the details of our sport and confabulation. Shortly, let us say, we have not another shot. After an hour's rest and warm by the parsonage fireside, and a glance at his splendid collection of representative local birds all fallen to his own gun, we bid him adieu, having as our share a couple of wildfowl, affording another illustration of Cowper's lines, as we -

'Share in the plunder, but pity the-birds.'

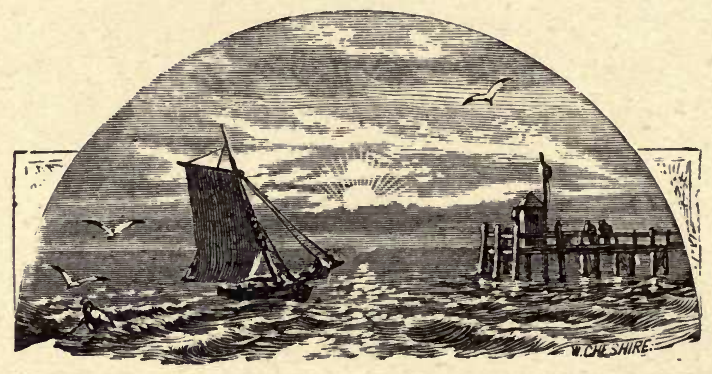




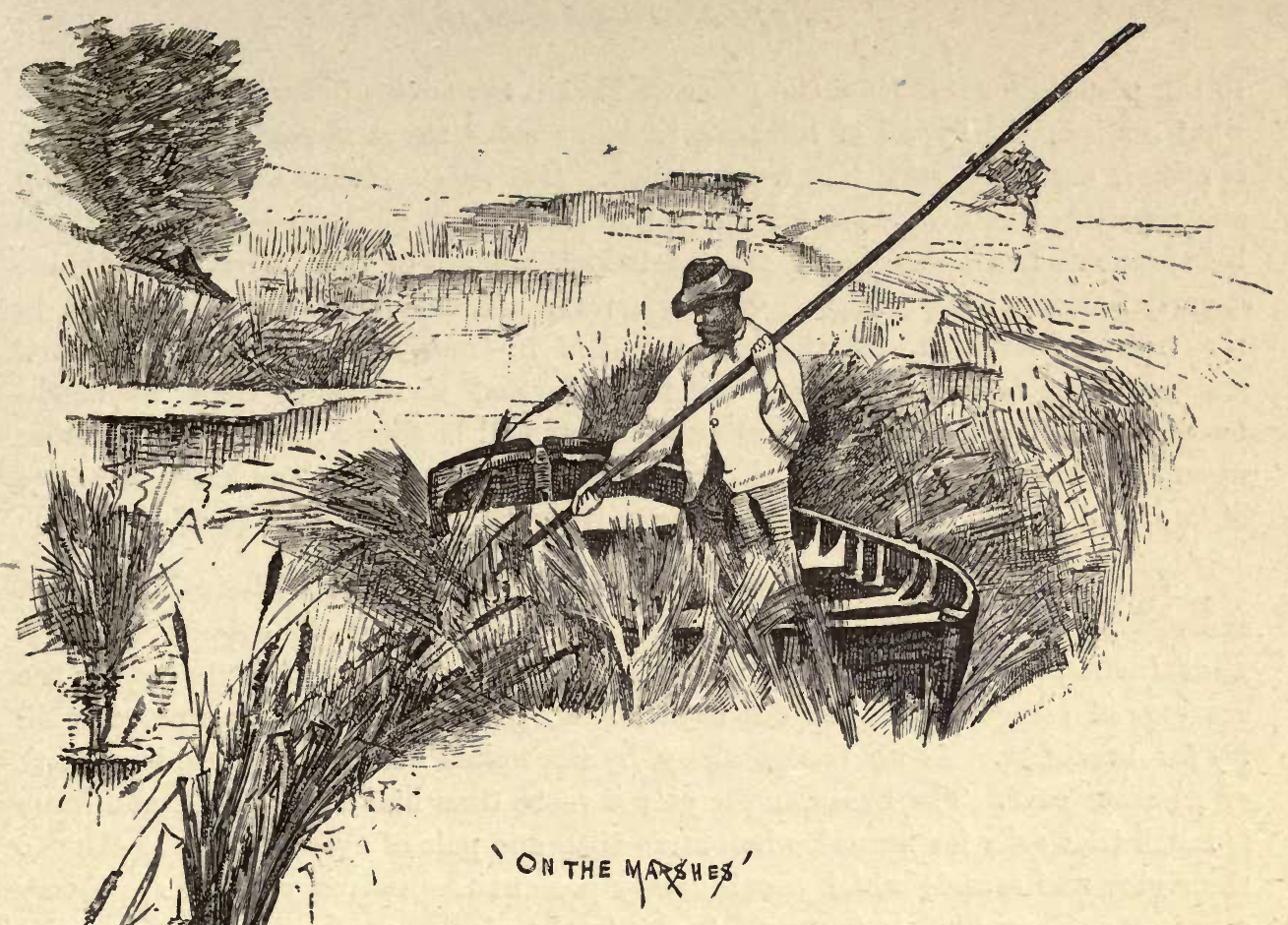

\section{FEBRUARY IN BROADLAND.}

'-At dusk steers homeward with a plenteous freight, The crazy vessel groans beneath the weight. A tidy housewife waits his coming home, Gets dry apparel, and cleans up her room.

And spreads a homely plenty o'er his board.'

-Life of a Fenman, 1771.

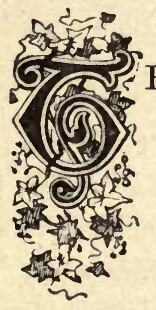

HE countryside has assumed a bleak and dreary aspect. The snows of January have given way before the drizzly rainfall. As our train rattles along through the barren fields which lie on either side our route, and spread away to the distant woodland, or are lost in the horizon, we cannot fail to notice the barrenness which characterises the environs of Broadland in the month of 'February-fill-dike.' Here and there Farmer Giles or his neighbours have fastened an unwilling team 
to the plough, for it is time the pease and beans were sown. The horses are somewhat restive; their spell of idleness, that has made them impatient of restraint, is ended, and hard work lies before them. Contented Hodge has been dressing and repairing the hedges, and lopping the willows and poplars; their shorn limbs lie alongside the hawthorns. In one field a number of graceful white birds are eagerly following the plough. We have time just sufficient to identify them as the train shoots into and through a belt of fir-trees, and the little Broadland station looms into view. They are seabirds, and none other than the blackheaded gulls (Larus ridibundus) whose nests will be found in the early summer upon the swampy 'ronds' that margin some of the Broads. Food has been scarce of late, and a meal of fat red earth-worms becomes a feast as well as a luxury.

We have travelled in pleasant company. A brace of well-clad fishermen, armed with the insignia of their craft, are bent on trying the case of Angler $v$. Esox lucius, for the freshwater shark of our reedy lagoons has yielded to the cravings of hunger, and come out from his lair in the reed-bed in search of small fry for breakfast. As we trudge along by the naked hedgerows there is no lack of pleasant chat. The Broadland angler is more than half a naturalist, and there is much that calls for remark when more than one pair of eyes are keenly alert to the sights and sounds which continuously present themselves, even at so gloomy a season. Greenfinches in small flocks fly hurriedly overhead, whistling noisy protests against meddlesome husbandmen whose radish-beds they have been too busily gleaning in. A couple of red-faced goldfinches are tamely pecking at an almost seedless thistle-tuft. We pass them at very close quarters. Who but the heartless birdcatcher could begrudge them their freedom? He is as sorry as we are at their perceptible decrease in the country, but his is a fox's grief.

'We'll bid you good day for the present,' is the parting salute of one of our impatient friends: 'Yow kin mardle (gossip) wi' the cadders (jackdaws) and ringdows, 'bor; but we hain't got no time to dawdle, so we'll jist gie ye the seal o' the day and be a-moving, jibes in angler number two with a merry laugh as he goodtemperedly wraps up his impatience in a bit of Broad Norfolk lingo.

Left to ourselves, we saunter on yet more leisurely, so many interesting tit-bits are turning up on every side. Now we peer through the hedge at some starlings foraging upon a manure-strewn field. What can it be that so absorbs their attentions? We clamber over the rickety gate to satisfy our curiosity, scattering the much-surprised squabblers, who make for the nearest trees to watch our strange procedure and await our departure. We find quite a host of brand- 
lings, which, unsavoury though they be, have gladly been found by the speckled stares. The earthworms have become cognisant of the slight change in the atmosphere, and are working upwards. The moles have followed them, and are making the pathside hillocky with their landmarks. Some remnants of snow, soiled and melting, lie piled beneath the hedgerow, where the rough winds but recently drifted it. A pale yellow primrose has ventured to open its delicate petals, and close beside it the young leaves of the coltsfoot are peering above the withered grassbents that the rains and snows of winter have levelled. The hazel on our right is already pushing its catkins out from their winter hiding-places.

The loud report of a gun in an adjacent market-garden startles us, as it does a number of little birds that dash over the hedge in precipitate flight. One of them, vainly striving to keep up with the others, staggers in its flight, and falls to the earth, which it reddens with its life's blood. A slight flutter and the poor birdie is dead. It is a bullfinch. Peering through the hawthorns we find the gardener picking up two or three other victims, and apparently well satisfied with the accuracy of his aim. ' 'Blood-ulf,' as the bird is named in Norfolk, is no favourite visitant to the orchard just now, for the plum and cherry, and even the gooseberry buds are set upon by those hard destructive mandibles; they say the good he does in other seasons is counterbalanced by the mischief he commits in winter, a statement that is very much open to question.

Watch that grey bird, with black wings and tail, and a dash of sable hue beneath the eyes! But he's watching us and takes to wing, disappearing in the orchard. It is a great grey shrike, or butcher-bird. Lanius excubiter, the 'Sentinel butcher,' as his Latin cognomen denotes, is expressive of his habits and his occupation. Here is a poor little wren he has impaled upon a thorn. We have disturbed him at his repast. Hearken to the tapping of the woodpecker; but we may not loiter to discover him. The rooks cawing noisily overhead are evidently commencing nesting operations. What an uproar to be sure! The redwings and fieldfares, busy still among the hawthorns, and their cousins the blackbirds and thrushes amongst the roots below, are passed unheeded by, as are the misselthrushes already nest-building in the topmost branches of an old pear tree.

We loiter just a moment when passing a keeper's lodge, with its interesting surroundings. Yon outhouse door is his ' museum.' On it are nailed many a real and supposed foe and depredator, from the marauding tabby-cat to the harmless kestrel, at whose hands - or rather claws and mandibles-his precious pheasants may or may not have suffered. Surely those barn-owls could never have conceived a thought of molestation. The rats on which, with field-mice, they almost 
exclusively preyed, have done more to merit vengeance than all the victims hung beside the really useful nightbirds. The marsh-harrier (Circus aruginosus), preferring vermin to all else, may have cast longing eyes upon the warren when hard pinched; but the keeper imagined him dangerous to his interests, and on the supposition condemned and executed him. Hither comes the gamekeeper-a rather uncompromising-looking fellow - with a ferret in each hand, and a brace of vicious curs at his heels. The rats have exhausted his patience, they have been woefully

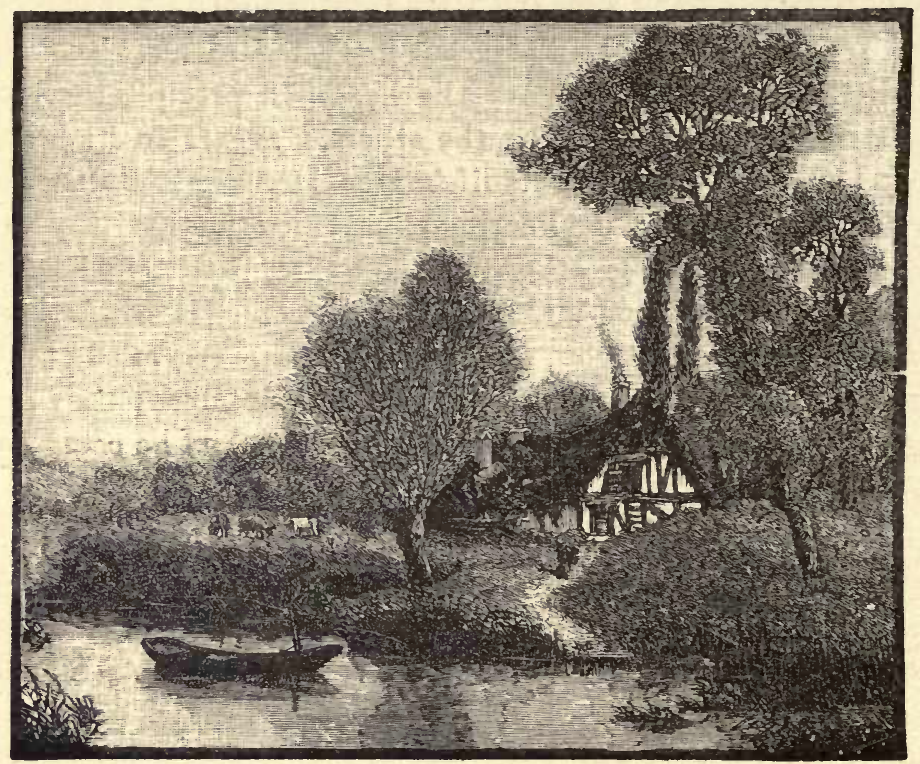

THE FENMAN'S COTTAGE.

on the increase, and small wonder, when their natural enemies have been so ruthlessIy and stupidly destroyed!

Here we are at length at the Broad margin. Yonder are our angler friends, busy, it is evident, our glasses revealing them tackling a reluctant pike. Close at hand are several ducks and swans probing the soft mud of the shallow 'deek' or boat-sluice that is connected with the Broad. They are seeking mollusca and edible roots. The fenman has thrown in some maize, of which they leisurely partake. How broken and colourless the sedges and stubble of other broad plants, and how bare are the straw-coloured reedstems of foliage! what of it remains is 
sere and drooping. We hear the calling of the moorhens, and at the farthest extremity of the reed-patch a dusky coot is cautiously paddling out into the open. Some wood-pigeons fly overhead. A flight of lapwings is discerned, and a small flock or two of wild-fowl are making large circles high in the air.

Hard by lies an old wherry. It has been heeled over by the boat-builder to get at some faulty timbers. Beyond this characteristic craft of Broadland waters is an old drainage mill, close by which, nestling among some willows, is the Fenman's cottage, whither we are wending our footsteps. A devious pathway, flanked on either side by a narrow lane of water, leads us to it. Let us step in, for we are not strangers here. The good old lady, whose deafness is to blame for not answering to our knock, bids us a cheery welcome. She has just spread the table against the old man's home-coming.

'Jim Trett's out hinder reed-cuttin', says his loving spouse, 'but he'll sune cum in, 'bor; sit ye down, for he's pretty reg'lar tu his males, 'bor, I kin tell ye!'

Whilst the good woman is finishing her preparations for the noonday meal we have a look round, taking stock of the room and its contents. The whitewashed walls are hung with several common prints of Scriptural or sporting subjects, a tiny looking-glass overtops the mantle in company with a faded sampler worked by the lady of the household when at school. A couple of cheerful linnets hang on either side of the window in the tiniest of cages, and beneath them are several geraniums struggling hard to brave the winter, and so far they have been successful. An aged cat upon the elbow of the old man's chair sits blinking at the fluttering birdies, thinking no doubt of times gone by when she was wont to hunt their fellows. A few oddments in the shape of wearing apparel, lines, a bird-net, and an ancient flint-lock gun, long past service, complete the furniture ' in suspension,' with the exception of a quaint old timepiece that swings its bright brazen pendulum as methodically and untiringly as it did when the good old folks were novices at housekeeping - fifty years ago. Three or four birch chairs, a side-table overcrowded with household treasures, a dilapidated bureau that contains the rest, with a sturdy table creaking beneath a plentiful repast, comprise the furniture of below-stairs. Everything-even the very brick floor-is as clean as scouringsoap and elbow-grease can make it. The old lady's snow-white cap encircles a face upon which simplicity and good-nature are finely blended amid the wrinkles of advancing years.

We have no time for further survey ere a heavy footstep announces the arrival of 'Jem' the fenman, who enters with scant ceremony. His boat lies 
moored close by the house, stacked with freshly-cut reeds. We are soon seated around the table, 'quite at home', and on the best of terms. What pleasant gossip makes the meal a luxury! Of itself it is one, for our viands are not unsavoury or badly brought to table. Who could say 'Nay!' to a leg of plump wild rabbit, snared in the little garden-patch outside, or to tender lapwing, shot but the day before upon the marshes? Did we like a piece of boiled pike and potatoes or a plate of potted eels? Did we not? And didn't we just enjoy a nice little cut from a wild goose's breast, and that wind-up with the richest of home-made bread with a bit of cheese such as you seldom find better out of the county? Rather! But that goose-it was a pink-footed fellow (Anser brachyrhyncus), so we told our host, who, not having shot the like before, so he said, had saved the feet for identification. He was 'gormed,' like Ham Peggoty, if he could 'spake them hard words at all!'-and good eating the goose was too; and the tea wasn't bad which washed down this strange Broadland repast. As for Jim, a huge dumpling, packed full of starlings, formed the principal item on his bill of fare. And the old fellow, with his tousled hair, his unkempt beard, and ruddy complexion, appeared to thrive on his homely fare and his outdoor life in the strong, pure air of East Anglia. And how does the fenman pass his time through each succeeding season? Let Jim tell us, for he has settled to his after-meal pipe, and has waxed chatty and communicative as the smoke curls upward.

'Well, yow see it's like this, 'bor, there's allus suffin' tu du, be the days long or short, and be they hot or cold. Start from tu-day, if yow like; I'm sloggin' hard in among the reeds jest now, and have been off an' on since Christmas, when the wather ha' let me. What du they du with the reeds? Why, use 'em for thatchin', mostly. Years ago, afore laths was riv', and sold for plasterin', we used to make a better figure on 'em than we du tu-day. Law ! times ain't noways like as they was long years ago; everything is changed-and for the wuss, at least for us fenmen. We ain't fenmen now, but simply lab'rers.

'Time was when we cud git our livin'-an' that's fifty yeer ago an' more-on an' out o' the Broad alone. There was allus somethin' in the fishin' or shootin' line tu du. Now-a-days it's reed-cuttin' in winter, mixin' it off with a little eelpickin' (eel-spearing) when the wather's open. Then cums ditchin' an' hedgin'. In June theer's 'haysel,' or hayharvest, for which we get pay accordin' tu day or acre or loads, jist as we agree for. Then there's gladdon-cuttin' for litter-that's the rough marshy stuff mixed with young sedges, reeds, an' so on. Later on cums harvest. Get that over, and we go arter the eels agin, among which we sometimes du pretty good bisness, 'babbin' for 'em, catchin' 'em in bigger numbers as the 
time goes on, in eel-sets, when they begin tu run (make for the sea). Now an' agin a job's tu be had a-rowin' gents out a-pikin', or helpin' 'em in the warmer weather among the roach an' bream. Takin' all these things intu consideration, with catchin' moles, and havin' an eye to the cattle on the marshes, and another on the old pump-mills, time gets filled in all yeer round. There's a pig in the sty tu help with the rent, eggs from the chickens ain't all loss, and gatherin' mushrumes pays for 'bacca. This ain't bad 'bacca yow've got here, sir, nohow!'

'Times is altered I was tellin' yow. Why, when I wor a boy, and the Broads wor freer than they are tu-day, and theer warn't no 'close seasons' for bards-and theer wus bards then, let me tell yer, I ha' known my father tu kill twenty mallard an' duck in a mornin'. There was ruffs an' reeves as used to nest hereaboutsthese we snared, and allus had a riddy market for 'em. Plovers' eggs cud be gathered by the peck; that's all dun with. A hatful takes a mornin' now tu git. Where are the bards gone? Why, theer ain't the bards there was. Du it stand tu reason theer can be when in $1821 \mathrm{my}$ dad took a hundred an' sixty dozen eggs in one season? And that was only a sample of plenty more. These eggs, let me tell yow was reeves', snipes', pewits', redlegs' (redshanks), and a fair dose of coots' an' moorhens' mixed in among 'em. In course they ' killed the goose as lays the golden eggs,' so tu spake; but there ain't the 'commadation for the bards, 'bor, now if they'd cum, for everywhere's all drained an' cultiwated. In winter my father cud pretty well keep us with the fowl he knocked over with that old flintlock an' the wegetables as he'd grown in the garden-patch. I get a few birds, as yow see, but it's a sort of favour as I'm allowed to shoot, for that sort of thing's done for pretty well among us fenfolk. Theer's licenses tu git, and the rich 'uns ha' got it all theer own way, and on the Broads the rights of owners so-called are more enforced.'

Dinner over we make for the Broad, taking a peep in the 'outhouse' on our way, wherein are stored his various scythes, his reedhooks, traps, and other implements; herein the fowls all roost at night, and drop in at leisure in the daytime, as occasion for laying prompts them. The pig hard by gives a squeal of recognition, and the ferrets in the corner rattle at the wires for a rat for dinner. We shove off from the little staith-he to resume his business among the reeds, our purpose being a row round upon the silent waters. We leave him pushing his old punt into the crackling mass, hands encased in 'dannocks' (leather gloves), sickle in one, and reedhook in the other. With this latter instrument he brings to book the straggling stems.

We have a peep into the pike-fishers' boat. They have secured some half-adozen fish, one huge fellow weighing at least a stone. Gulls are winging to and 
fro over the dark waters, picking up here and there some defunct fish. Two are quarrelling over a dead eel that the recent frosts have killed. A Sclavonian grebe is dipping here and there in the now rippling waters, for the winds are stirring and sending up the promise of more rain. A flock of widgeon wheel round and round overhead, and finally descend, dashing themselves upon the surface with the impetuosity peculiar to the race. But time is going, and great rain-drops are making concentric circles upon the Broad. We row for the fenman's cottage, arriving at the mooring-stage simultaneously with the good man himself. A flock of lapwings are beating up against the wind within gunshot. The old man snatches up his muzzle-loader, which lies in the boat, and brings down a trio of the unfortunate plovers.

After another cup of tea and another interesting chat, we take our leave, hoping to revisit Broadland in the blustering month of March. 


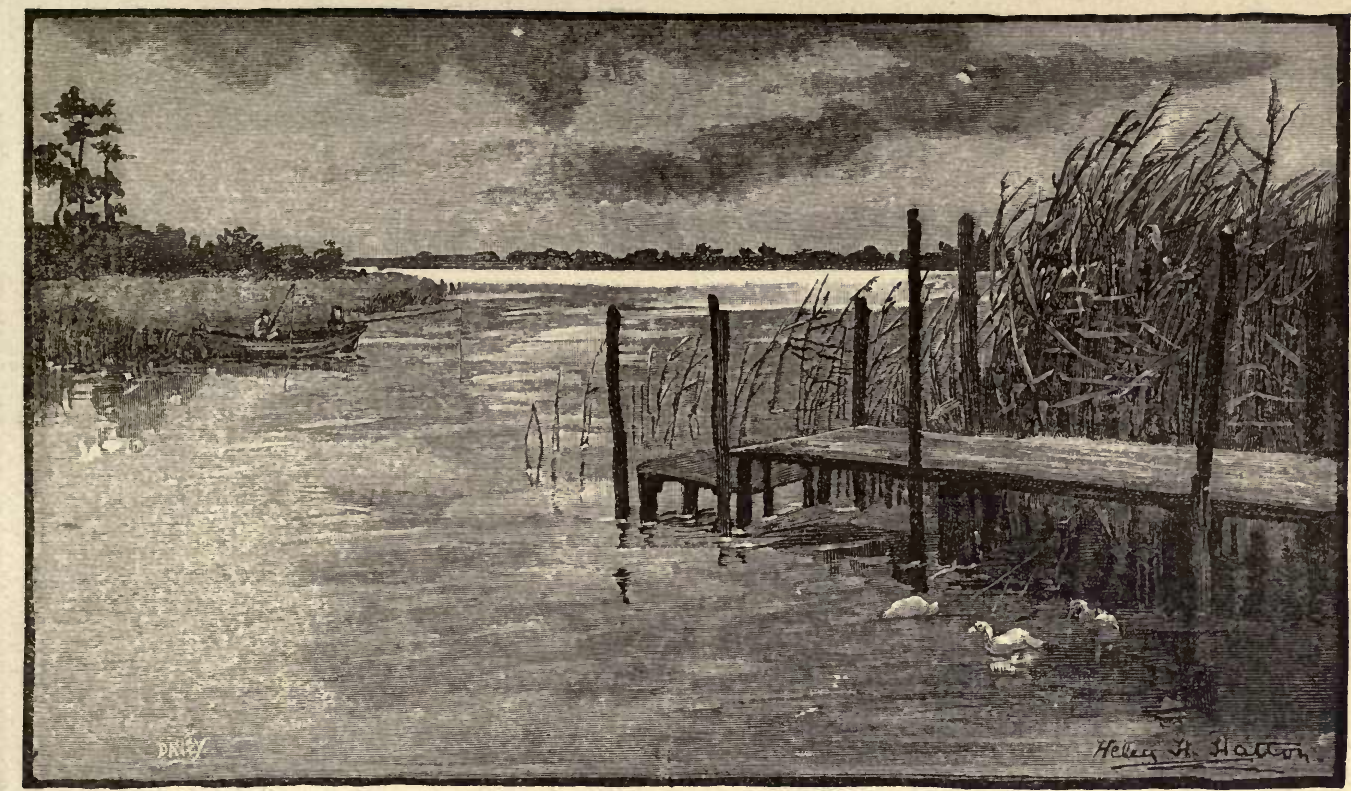

ORMESBY BROAD.

\section{MARCH IN BROADLAND.}

'Let me live harmlessly, and near the reedy brink

Of Broadland waters, have a neat thatched dwelling-place,

Where I may see my dancing quill or cork down sink,

With eager bite of bold, bright perch, or rudd, or dace.'-Walton (adapted).

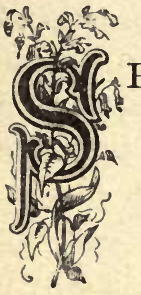

PRING is now but a short way off us, and between the bursts of wintry weather which the storm-king flings over the face of Nature she essays to put on a cheery smile. In one of these sunnier moods of Nature we are tempted to venture Broadwards for a turn amongst the perch, for our lines and rods have been idle these many months, and perch are becoming hungry. Lobworms have been difficult to procure, but patient searching has not been unrewarded. 'Angling, in my judgment,' says old Izaak, 'deserves to be commended,' naïvely adding in effect that ' there are no practices that deserve commendation but may be justified.' Sir Henry Wootton, one of Walton's piscatorial friends, used to tell him, 'Angling was, after tedious study, a 
rest to the mind, a cheerer of his spirits, a diversion of sadness, a calmer of unquiet thoughts, a moderator of passions, a procurer of contentedness, and that it begot habits of peace and patience in those that practised it.' But contemplation may do for warmer days when sport is uncertain; action and brisk sport are necessary to proper enjoyment in the chillier days of March. There is pleasure in preparation and in the very anticipation of it. We are in a very short time whirled from the busy town into the heart of Broadland. We noted little difference in the fields and market-gardens through which we were hurried; certainly the farm labourers seemed somewhat busier than in February, for the sowing of oats and barley is claiming the attention of the farmer. The strange antics of a lad in one field did attract our notice, but we were beyond him ere we could make much out of him. It was evident the proceedings of a crowd of great birds that blackened the field were not to his satisfaction, and to frighten these away was undoubtedly his intent.

As we wend our way through a lane we witness the selfsame thing. repeated, and upon the light wind is borne a noisy clapping sound, and the words of a strange weird ditty:-

'Cadders and crows, take care o' yer toes,

For here cum the clappers

To knock yer down back'ards,

So hallo! Carwhoo:

It may be that the sable birds are laying claim to a few of the seeds that 'fell by the wayside,' as their ancestors did in the days when the God-man taught the people in parables. Christ was a keen observer of bird-life, and who can say that He did not teach many a lesson from their ways and doings that are not recorded in the Book?

Seeing us lagging by the gateway the crow-boy sidles up and wishes us the ' seal of the day,' accompanying a rough clumsy bow with a good-humoured grin. With an eye open to a 'largess,' the Norfolk equivalent to the Eastern 'backsheesh,' he allows us to examine the grotesque implement which is supposed to put terror into the hearts of the so-called crows, which are in reality nothing more than harmless grub-eating rooks. We find it constructed of three pieces of thin wood, oblong in shape, the centre one being lengthened into a handle. The two outer pieces are loosely tied by strings at their lower ends, which go through a couple of holes in each. When shaken a loud rattling sound is produced.

'And so you scare crows, my lad?' we query.

'Wal, 'bor,' he replies, 'I'm tryin' tu; a little scarin' oan't hart 'em? Why doan't I shute some on 'em, and hang 'em up to scare t'others? Yow can't per- 
suade owd Farmer Giles tu du nothin' of the kind, for I heer'd him say tu as how, when he wor young, he knocked 'em over all ways, an' what did it du? Why, his crops wor simply spiled with the wire-worams an' other critters the rooks are fond on. Du yow see them white bards hinder? Them's sea-mows (gulls). They're the master-piece bards for pickin' up worams (worms). I ha' seen 'em so full of 'em as they couldn't scarce fly. Du I know a rook from a crow? I shud jest think I du. They ain't the same at all. Rooks prog togither in flocks, crows doan't. Crows ha' got brussels (bristles) round the top bake (upper mandible), an' rooks ha' got white skin on instead. Crows like dade things better 'an grubs and corn an' taters. Du I like the job? Wal, I doan't mind it, there ain't a sight o' hard work about it. Thankee! sir, but I must be a-goin', yinder rooks are settlin' athowt the field, an' master'll wonder if I'm clean gone tu sleep or if I'm shanny!'

Our merry crow-boy slouches away repeating his clapping and his merry refrain. He appears an intelligent lad for such brainless labour, and withal seems contented with his lot. He is not the lout his fathers were, for the days of compulsory education had dawned not in their time. The yokel reads and thinks to-day, and is not the serf in body and mind to the squire and parson as he was a generation or two ago, whilst the squire and parson are more tolerant and broaderminded than many of their predecessors were. It is well that 'larnin' does not drive all the lads from the ploughtail, and make them discontented with the dull monotony of an agricultural life. Our crow-boy may be tempted in the autumn, like many of his class, in this district, when harvest is over, to join a fishing crew and pursue the North Sea herring fishery. And will he be acting contrary to the instincts inherited from his forefathers the old Vikings, who were fishermen and farmers as well as warriors?

It is a glorious March morning. The blustering winds that ushered in the month have dried up much of the moisture February left behind it. The sun has forced a passage out between the clouds that obscured his face earlier in the day, and his rays are lighting up the lane ahead of us. With the weight of paraphernalia we are carrying, for we are laden with the trappings of the angler, we can easily believe old Sol is gaining strength; indeed, the perspiration is standing in little beads upon our foreheads. There are no conveyances here from the station to the Broad until the warmer days shall lure larger numbers hither. It is ten minutes since we rested by the scarecrow's gate. Let us sit a moment or two on this grassy bank. A startled thrush dashes out of the hedge hard by us. See! it has already built its rough clay-lined nest. There are a couple of eggs within it. A pair of chaffinches on the tree behind us are choosing a site for the erec- 
tion of theirs. Heigho! here's a little violet peeping out from the bank-side, and another. How beautiful they smell: it was the scent and bright blue that betrayed them. Daisies dot the sward with their pearly faces, and in the holl (ditch), beneath the blackthorn, are some pale yellow primroses, which contrast strongly against the dark green leaves that sheltered them while they were yet unfolded. Those golden flowers nearer the water are the starry petals of the pilewort. The humble-bee has ventured out; the catkins on the sallow upon our right have attracted several of these droning insects. The leaves of the honeysuckle in the hedge appear ready to unfold. In the field beyond, the young grass has carpeted the soil with brightness. There goes a rabbit, and another. How the merry things frisk and gambol! A small flock of wood-pigeons, loudly smiting their pinions, pass overhead in hurrying flight. But for our presence, which they observe not until close upon us, they would most likely have dropped down in the wheat-field behind us for a dinner of the young sweet blades. What wild shy birds they are! And notwithstanding the constant persecution to which they are subject, they seem yearly on the increase here.

Quietude and motionlessness are two great essentials to observation; and if the naturalist would insinuate himself into the good graces of Nature he must bring both qualifications into exercise. Note that hare! hither it comes limping along the road. Ab! your movement caught his quick eye, and with a hasty bound he has darted through the hedge. How strange it is, that when unsuspicious of danger, the hare sometimes keeps straight on, and almost runs himself into it : The position of his eyes may account for his not seeing so well ahead as on either side of him. Did you observe that small brown head peering above the bank? There it is again. It is a stoat. He has scented the unlucky rodent, and has already got upon his track. So pertinaciously does the stoat keep upon the trail of an intended victim that we may be almost certain poor puss will fall an easy prey to him. A frog just now 'plumped' into the ditch: this must surely be his first day's outing; all winter through he lay snugly asleep in the mud below. The little birds grow bolder; and so long as we remain quiet, they pop in and out among the thorny twigs and budding tree-sprays.

But, friend Piscator, it is time we were moving. It's getting well towards the noon-hour. The waters of the Broad will lie before us when we get beyond the village 'pub.' Going inside? Well, we might do worse, if we might do better. But a jug of hot steaming coffee, and some sweet white bread and a bit of cheese will the better befit us for a foray amongst the perch. The genial host is profuse in information, and obliging, as is the wont of his fraternity, to the 


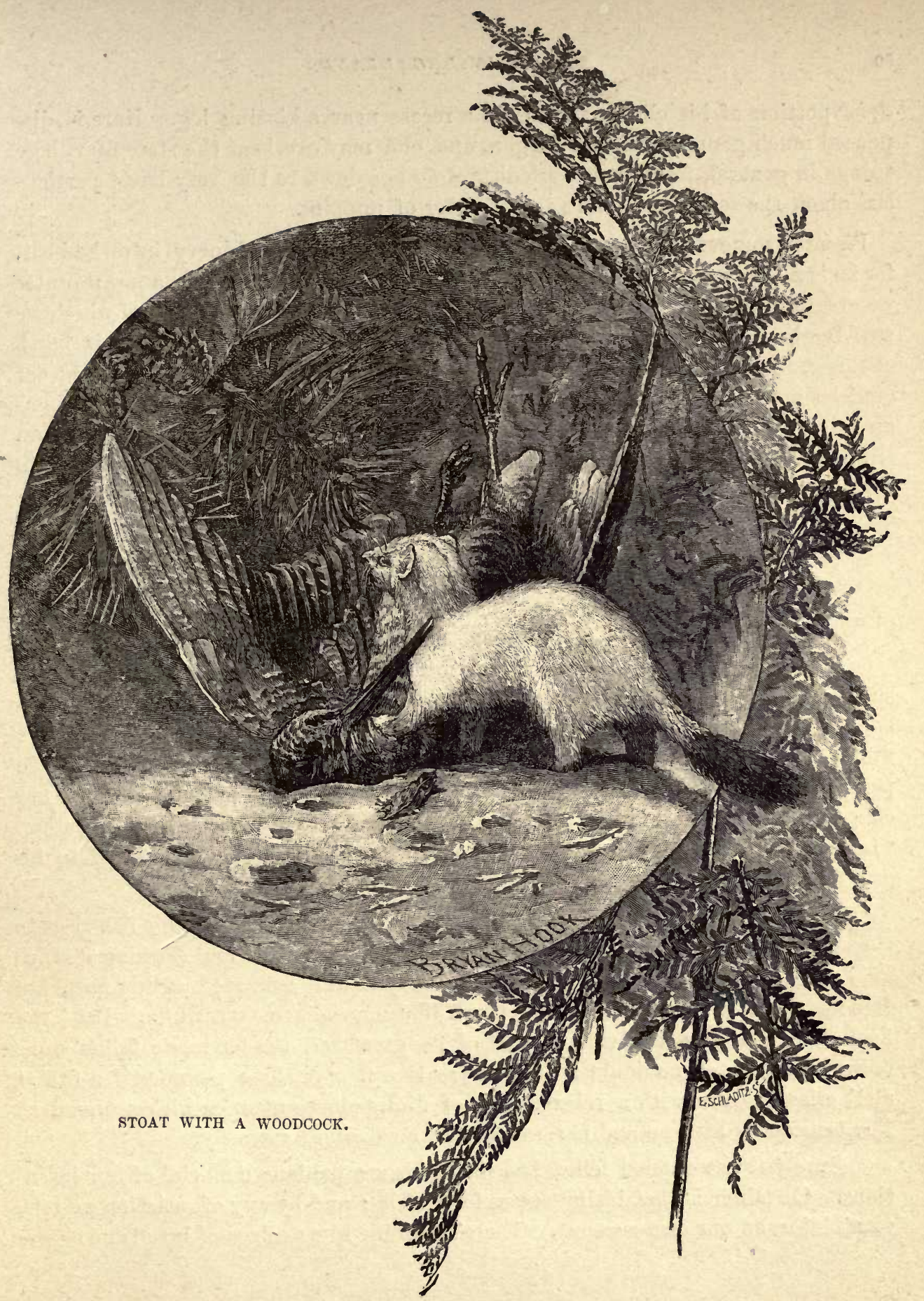


drier portion of his clients sitting in a recess near a blazing log. Here is dispensed much genuine Norfolk jargon, and one may overhear the state of village things in general, from their agricultural doings down to the very latest particulars about the squire's spaniel's recent litter of puppies.

Piscator somewhat clumsily tumbles himself and his machinery into the boat, for he is a heavy as well as an ancient member of the fraternity. In a few minutes we are pulling over the rippling surface of the Broad, by the margin of which we swiftly glide along. The coots are making love in the yellow reeds, their harsh clicking, like the sounds of the driving of stakes, being hushed as our right oar crackles among the brittle stems. There must be scores of them. The moorhens are also en evidence. Quite a little colony of them flutter hastily into cover, trailing their long lobated feet upon the water, churning it into little bubbles in their progress, as we turn a bend in the interminable array of straight sere reedstems.

'Here's a good hard bottom,' quotha Piscator, ' and it's nicely under the lee.'

Very good. We gently drop our huge flintstone anchors in about ten feet of water, and throwing over a little ground bait, affix our rods and tackle.

Piscator is loud-yet not too loud, for suppressed exuberance is essential to success as much as baits-in praise of some flat-tailed lobworms, which he has had under training in soft, damp moss 'this fortnight.' We wait not long for a nibble. Our float suddenly disappears in an oblique direction. A goodly-sized perch has evidently gone away with it. We strike, and manage to hook our client, which strains hard at the line, now rushing this way and now the other. 'Landing net, quickly!' but Piscator's attention is simultaneously called to his own float, which has also vanished.

'Eh! what a beauty!' he ejaculates as, shaking itself furiously, his fish rises to the surface, cutting the water with its stiff-spined dorsal fin and showing its 'fins of 'Tyrian dye.' Our friend's face is a study as the workings of his mind are depicted upon it. It is a knowing perch that manages to outwit him. Bah! the hook has given way, and with a swirl of its great tail the fortunate fellow sinks down below to tell no doubt a tale of treachery. 'A three pounder if a fish at all!' cries Piscator with a relaxed look of disappointment upon his countenance. The.tension on his line and nerves has slackened simultaneously.

Surely that wounded fellow has made his companions doubtful of our intentions. Certain it is that biting ceases for a while; and by way of variation we take to nibbling on our own account. There's nothing like a solace of bread and cheese 
when a 'fluke' has happened. Sitting quietly, the various birds around us become assured, and take but little notice of us. The grebes have returned from the estuary; they are coyly coquetting not far away. What beautiful crests of black and red adorn their noble-looking heads! Soon they will be piling up those rotting leaves into a platform for their rough, dull-shelled eggs. Who has not peered into a great grebe's egg-basket without being struck by the swampy state of it, the very eggs barely escaping the water that filters in! But they take some finding, for the birds are adepts at hiding, and such mimics of surroundings are they. Those little birds that dashed out from the reed-bed are willow-wrens, surely; and that loud harsh cry from the tree-clump was the note of the wryneck. The latter is an unusually early arrival.

The mallard has already paired off. Yonder fly a couple. The plain duck is being playfully pursued by her handsomer lover: some petty difference, or maybe the prying of a busy otter, put them to flight. What a splash they make as they strike the open water and settle there for an amorous gossip. The white, bald forehead of a coot is seen as it peeps out from between the reeds; now another more boldly ventures out. They are not pleased with our close proximity. What a noise yonder rooks are making in the tree-tops! What squabblings over bits of sticks and twigs are indulged in! Unjust appropriativeness is a vice that is not exclusively human. A flock of brent geese pass overhead, northern bound. Some bearded tits are surveying the reed-clump yonder, as much in search of nestingquarters as of seeds or insects. The mellow call of a redshank from an adjoining 'rond' is distinctly heard; and a pair of lapwings are noisily flying over yonder field.

'You've a bite!' 'All right, Piscator. And you've a nibble.' In giving his rod the wrist, a huge sandwich is jerked into the water; but what matters that when business is becoming brisk? The moorhens will profit by the accident. This time we land a fish apiece, both 'sizeable' specimens, as the saying goes. Two or three others are landed in course of time. Away goes our float again. There's a big fellow at it this time surely. We strike him; and then begins a game at give and take. What a whopper he must be! it takes some manœuvreing to bring him to the surface; when lo! to our surprise, we find we are fast to a fair-sized jack. The lob-worm smote his fancy. And we finally lay him panting in the boat.

The strengthening of the wind brings our finishing cast earlier than it would have been; but there is every appearance of an increase of it. The air is growing keener. On our way back to the staith we nearly clash oars with our old friend the fenman, who has been getting in the last few rods of reeds. We are sorry to 
decline his invite to drop in and have a cup of tea, for the day is waning apace. It is stiff work pulling against the wind, and the dark waters are furrowed with foamy billows. We miss the starlings from the reeds to-day. They have already begun to think of housekeeping in the busier town.

Observe yonder big hawk-like bird! What grand sweeps it makes across the reed-beds. It is a marsh-harrier (Circus ceruginosus). We are fortunate at seeing such a noble bird. It is beating the reeds in search of a supper. See! a poor little moorhen, unluckily taking to flight instead of diving, is speedily pounced upon. It has struck its needle-pointed talons into the water-fowl, and has now settled upon a tussocky promontory that runs out from between the reeds. The game-keeper will be eager to level gun at the outlawed bird when occasion offers, for unfortunately, it does not always confine its attentions to such worthless game as this-at least he says so.

We have not yet caught sight of the swallows, for none have at present arrived. The fieldfares and redwings are missing; they have gone back to their northern homes. We have not heard the cuckoo, for though

'In March-he search,

In April he shows his bill.'

What ducks are those in the distance-some hundred at the least? Lend us your field-glasses, Piscator. They are widgeon. They are en route for the morasses of colder latitudes, but have dropped in for a rest and feed. It is tantalising to the gunner, whose right to maim and kill ran out on the last of February; and the widgeon is no despicable morsel upon the table. We wonder if our old friend, the fenman, has any scruples upon the matter? Why! here comes the old fellow himself, rowing as hard as his toughened arms will allow him. We await his coming.

'All right, guv'nor! but I jest thowt as how yow might like a tit-bit for yer dinner to-morrer,' he ventures to say, giving a knowing look at us and another at Piscator. 'Them owd perch oan't cum up tu a good cock smee (widgeon) with a onion tucked inside him. Yow can put 'em under the scaly ones if yow fale at all nervous; but lor, sir, how kin a feller keep his finger off the trigger when sich a pretty little dinner-piece gets in front of his fowlin'-piece?'

We send the old gent back to the 'missus' in very good spirits, and quietly place the birds where he suggested. Who would condemn us? The thing comes about so irresistibly, and the most exemplary of us are amateur poachers at the worst, and at the best the hunting instinct still lingers in us. 
The last of the rooks has gone home to his roost, the sparrows have got over their squabbling for perches and prestige in the ivy, the larks have settled in the wheatfield, and the partridge is calling his mate in the brushwood, as we enter the Broadland station, well satisfied with our exploits and glad to escape the rain that has begun to pelt down in a drenching shower. As we rattle along Piscator waxes chatty and even eloquent over the praises of Broadland; and the habits and characteristics of its finny inhabitants are expatiated upon at length. ' What sport,' he queries, 'can be so harmless or delightful, so gently exciting, without tendency to revelry and riot, requiring so little exertion of body or incurring such a minimum of risk? What a trifling expense does it run one to, and what can be more conducive to health and one's general well-being? One gets free from the foul atmosphere of the shop and office, away from the worry and cares of business; and, mind you this, a man up to his armpits in business and the worries of every-day life must have relaxation and recreation, or a break-down will come sooner or later. A man may here turn his back upon toiling and moiling, and enjoy Nature in her quiet beauty and retirement to the full. His surroundings and gentle pursuit banish dull care away for the time being, and he returns home to his duties invigorated and none the worse able to meet life's disappointments and reverses, as well as better able to appreciate its blessings. I say Hooray! for the life of an angler, and success to the general craft!'

Our friend's eloquence so far carries him away that, oblivious of what his creel contains, his hand comes down upon it with a bang, when lo! in a confused heap tumble tins, tackle, fish, and wildfowl, and upon the top of them fall rods and himself as well, as he makes a rush to prevent this consummation. He has barely placed things in equilibrium when the face of the ticket-collector appears at the carriage window, and a stentorian voice utters the orthodox and stereotyped, 'Tickets, gents, please !'

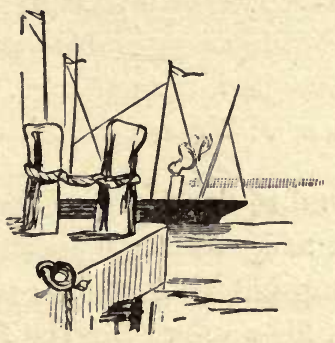




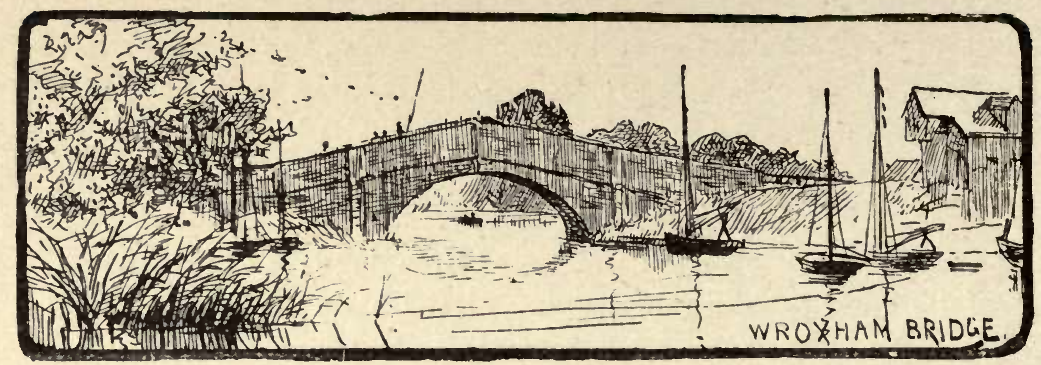

A BROADLAND BRIDGE.

\section{APRIL IN BROADLAND.}

'Beneath a willow, long forsook, The fisher seeks his customed nook;

And bursting through the crackling sedge,

He startles from the bordering wood

The bashful wild-duck's early brood.'-Warton.

HE days of mingled shower and sunshine have dawned upon peaceful Broadland. Lured by the warmer days of an April sun and the refreshing raindrops, nature has assumed a pleasant smile. The pale young leaves are everywhere eagerly unfolding their beauties, and the joyous birds are making the countryside merry with glad song, above them all, towering heavenwards, the skylark pours out the fulness of its little heart in praise to its Creator. 'All Thy works praise Thee!'

The clank of the bit is still heard in the fields, for Farmer Giles and his good man Hodge have not yet completed their sowing of the seed for the winter crops, and it is pleasant to hear the cheery 'Who-oa!' of the ploughman as he rests for a moment the panting horses, while he runs his eye with justifiable pride up the straight, clean-cut furrow he has just turned over. We can excuse his self-congratulatory remark - 'Th' Prince o' Wales couldn't cut a furrer claner if he tried, 'bor!'

We have reached Broadland to-day by road, for what can be more delightful than a country drive when the hedgerows are putting on their bright new vesture, and the wild-flowers are peering out from their mossy nooks beneath them, and the little birds are playing at hide-and-seek in the thickening foliage, preparatory to settling down to the sterner duties of domestic life? It has been a glorious 
jog-trot; and Boxer has had matters pretty well all his own way to-day, and, mayhap, has been wondering if we'd forgotten to bring the whip, for it's little hur'ying he has had these six or seven miles. Who could scramble across country, notwithstanding a smart passing shower necessitated the outbringing of the big green gingham strapped behind the footboard, when so much that is lovely invited our

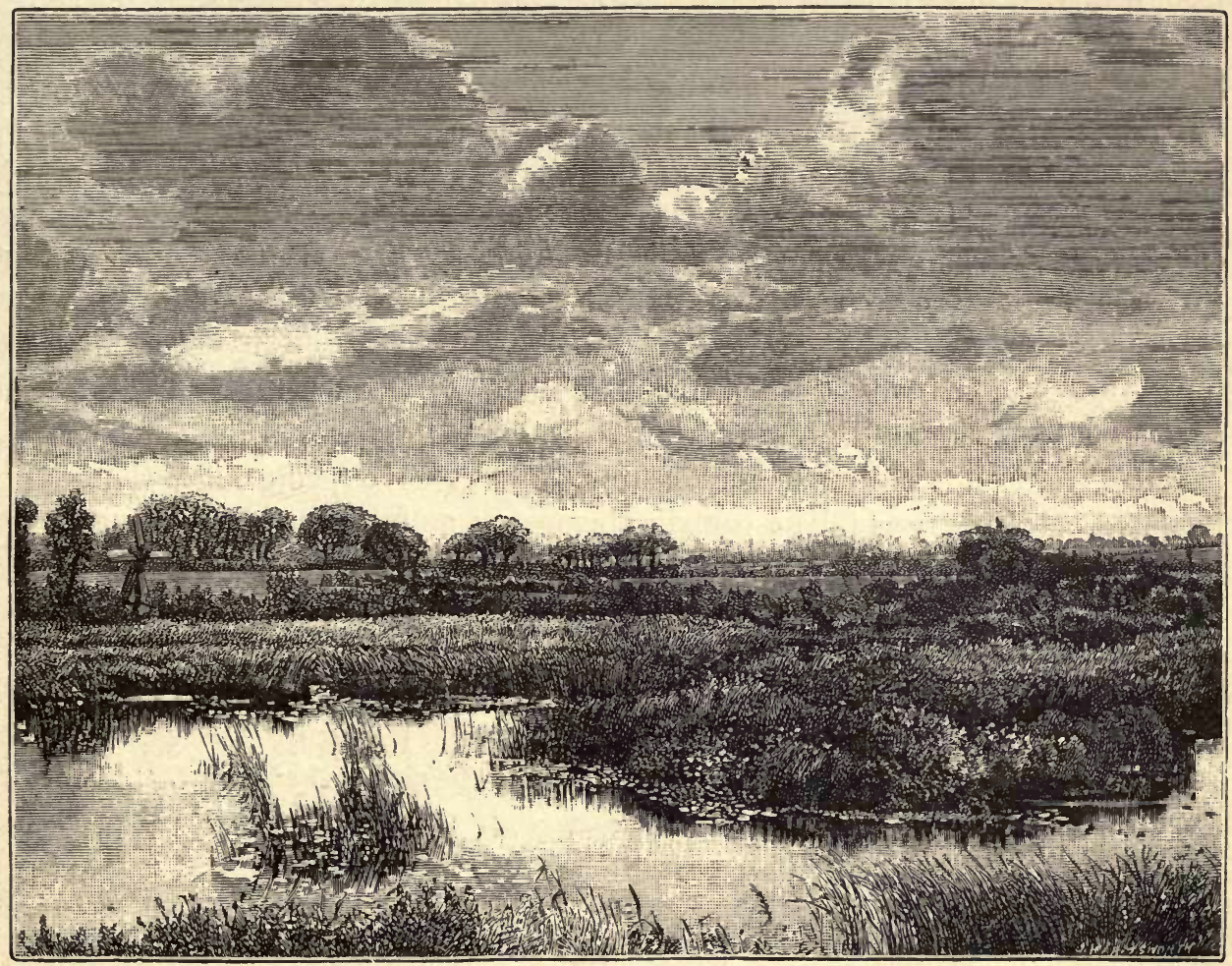

attention and our admiration, and the praise of Him who pronounced as 'good' the creatures of His hands? There was scant room for an agnostic in our vehicle. The blue of the harebell, the ruddier tints of the wood-sorrel, and the pale yellow of the primrose contrasted delightfully with the fresh green blades of the various grasses which are shooting up their myriad spears. How refreshing to the eye were 
the meadows dotted with 'buttercups and daisies,' and even the more barren patches on the uplands sprinkled with the broad-leaved coltsfoot, from among which peered the starry flowers of yellow. And then the birds! Have they not been conspicuous by their presence and their song? The wayside hedges and the woodland are peopling rapidly with the immigrant songsters; the harsher cries of those that roam this district in the barren winter are replaced now by the cheerier melodies from a myriad little Southerners' throats. But we are anticipating.

The wheels grind heavily at times when rumbling up and down hill, for the recent rains have made the roads so soft and, in places, somewhat sloppy. Observe those pied wagtails at yon roadside puddle. How oddly they flick their elongated tails as they daintily run beside it. It may be there are some tiny midges gyrating over the pools, which have smitten their fancy. They take to eratic wing on our approach. Rooks have seriously settled to household duties. Such cawing from daybreak until dusk returns is the order of the day! surely the old elms never could have had noisier tenants! That small bright-brown birdie upon that hawthorn spray is a redstart- ' firetail' the natives call him. Its plaintive wheet-wheet! becomes a familiar sound in the woodland in the month of April.

Our steed pulls up at a horse-pond to take a sip. We spring out of the vehicle impelled by curiosity to take a peep in amongst some fern-fronds uncurling to the warmth of springtime. A tiny bird has just flown out, and upon a bramble is fussily uttering its quick-repeated notes. It is a chiff-chaff. See! in the stubbly remnants of last year's grasses, snugly sheltered by the fern leaves, is its nest. Six small creamy-white eggs are the treasures which have become a care to the half-frightened, over-solicitous parent. Never fear, bonnie birdie! we touch not such precious objects. The chiff-chaff suddenly darts down in the thorny hedgerow. A shadow as of a larger bird glides across the horsepond. We look up, and discover the greater occasion of alarm in the shape of a hovering kestrel.

The speckled bird of prey might have had one eye upon the little percher, with 'intent malicious,' but it certainly has had another upon a. venturesome field-mouse in the mead beyond. Down like a stone it descends upon the hapless rodent; and as it hies away to some familiar rail stump, whereon to devour it at its leisure, we can discern the wretched creature struggling in the bird's sharp talons. In turn the kestrel takes to precipitate flight; its quick eye has detected the approaching gamekeeper, who, silly man! has sworn, some time or other, to take away its life. Can he yet be so ignorant as to imagine this hawk is anything else but one of the greatest friends of the farmer, and the rearer of our gamebirds? Several house-martins, conspicuous by the white upon their backs, on 
rapid wing dash up and down above the horse-pond, and disappear over the firs that border it, and again as suddenly return.

We are afloat once again upon the limpid waters of the Broad. Boxer is munching his well-earned fodder in the reed-thatched stable behind the village

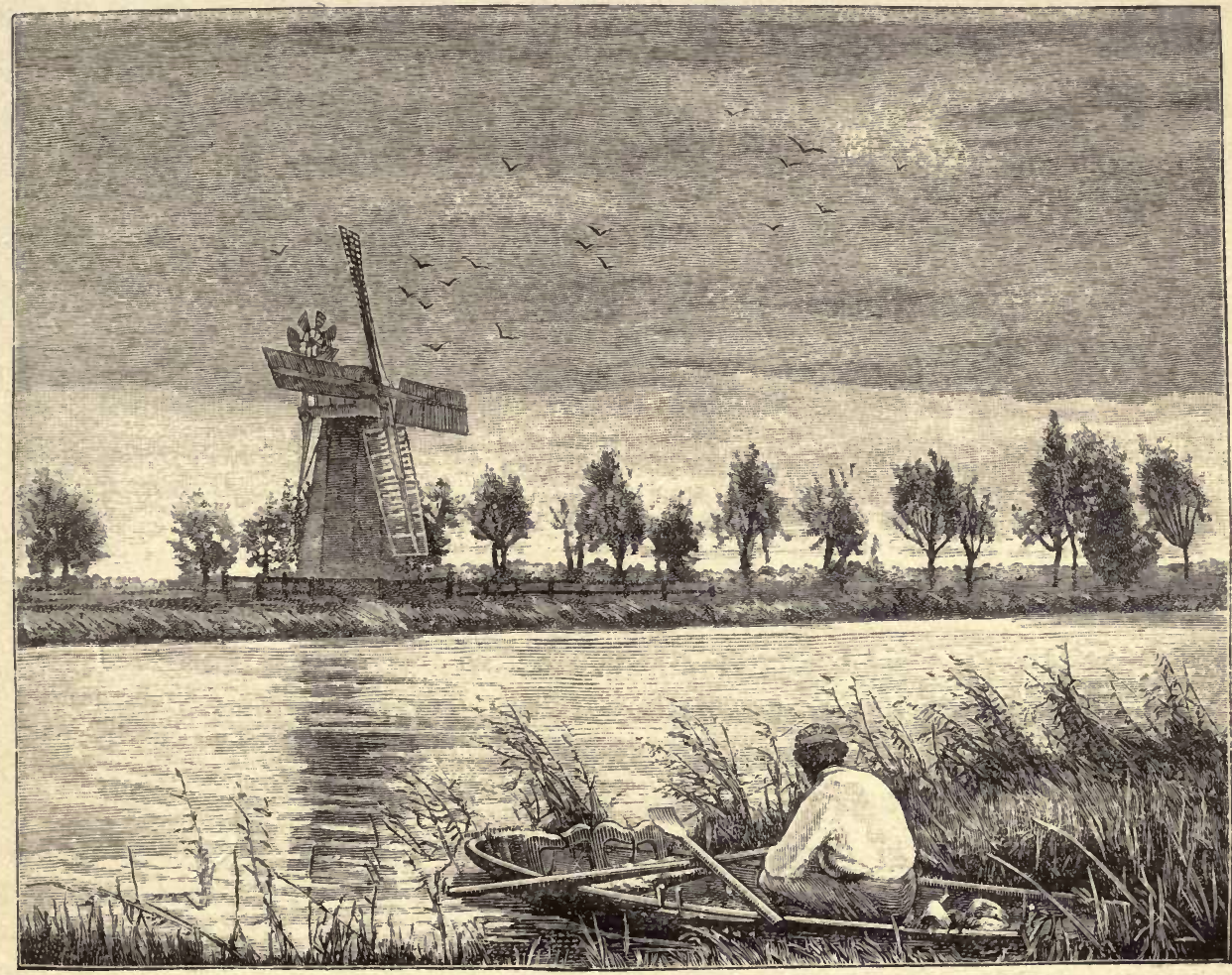

inn: the knowing old animal enjoys a Broadland visit to the full. Signs of life are showing everywhere around us. Last year's sapless, leaf-denuded reedstems are growing thinner, and the remnants of those broken, and the débris of the sedges and the rushes lie in a confused tangle, more inextricable than if woven among them, upon the surface of the water. Left, unfortunately, to decay and 
rot, and then to sink beneath, year by year this accumulation makes fresh soil, and so as time rolls on the Broads become more circumscribed in area.

Thus it is that some of the smaller broads are now scarcely bigger than fishponds. Gradually, but surely, if imperceptibly, the swampy margins have extended. Then appropriation commences. Ditches are cut, and pump-mills are erected. Years long gone by the skeleton pump-mill did nearly all the work, then the tower-shaped article came into vogue.

Powerful steam mills are now found cheaper to work and more effective. And thus has it happened that the erstwhile resort of snipe and bittern is covered with waving grain; and the partridge gleans amid the corn-stubble above spots where the rudd and the bream, not many years before, were rooting and grubbing after larvæ and mollusca, amongst the sub-aqueous stems of reed and bullrush. Changes similar to these have reclaimed the fens from a chaos of waters to fertile acres, where sleek, fat kine deem life well worth the living; and no sooner does the heavy rainfall swamp the lower corners, and fill the ditches, than the sails of the quaint old mills are placed before the wind, and the excessive water is pumped, or otherwise thrown by a huge water-wheel, into the sluices connected with the sluggish river. By this means miles of marshes, separated from the tidal river only by a bank or 'wall,' themselves below the level of flood-tide, are kept free from inundation.

As we slowly scull across the rippling waters of the Broad, we are roused from our rather pessimistic reverie by a noisy tumult as of quarrelsome birds: a cuckoo skims across a reed-bed to the terror or annoyance of some marsh-tits that had been busy in among them. They join a mixed mob of tits and finches that are already at its heels. Have they mistaken it for a hawk, or is it a protestation against the cuckoo's fondness for usurping the rights of their little homesteads? A pair of black-headed buntings pass just above head. Several grebes are disporting themselves in the water ahead of us. What a merry life is theirs when unmolested! Their plumage is now at its best. Observe them through these glasses. What curious crested heads of white and brown and black; and what slender snake-like necks ! One or two evidently are fishing. Let us lay-to beside this tiny promontory on our right and watch them. There is a stake, left by some angler, who no doubt had a mind to erect a 'land-mark' to some propitious perch hole: tie the painter to it.

And now whilst discussing luncheon we shall have a better chance of observing the birds around us, for nothing conduces more to their hiding than the dodging to and fro of suspicious overlookers. What appetites the Broadland air gives 
birth to! There ! it's just as we predicted. The grebes, emboldened by our silence, have been paddling well this way. How rapidly they swim! There's at least halfa-dozen of them. Now they dive. One has suddenly appeared above water with a juvenile roach between its mandibles. A couple fly past us in grotesque flight, with necks extended, and with hanging feet. This characteristic bird of Broadland was at one time in danger of extermination, when the craze for grebe-skin muffs and trimmings was stronger than the dictates of humanity and reason. Reedwarblers peer out from the yellow reedstems. They will shortly be nesting. But we will forbear to trespass on their privacy. Weaving their cup of a nest when the young green shoots are but a few inches above the waters, as we see them now, and using some three or four as a kind of scaffolding, little by little it is lifted - as the reeds grow longer, until, by the time the greenish-white, brown-blotched eggs have become replaced by the downy chicks that inhabited them, it is suspended at least a yard in air!

A little bay sweeps away on our left. The clicking of the coots has somewhat subsided. Surely there must have been some scandal going on this morning amongst them. See! a dark object has just come out from the reeds into the open water; another follows. Those white foreheads make the coots' identity unmistakeable. Three or four red-billed moorhens are cautiously paddling in an opposite direction. There now! your clumsy stumbling on that oar has caught their quick ears and vision. How the moorhens take to startled flight, trailing their long feet upon the surface of the water until rows of bubbles follow their receding forms! The coots dive under and we see no more of them. They evidently come up in the reedy phalanx where the eye cannot penetrate.

Behind the reed-bed is a clump of alders. Willows point upwards their slender twigs. Behind them, and where the taller trees blot out the landscape beyond, are some silver beeches, contrasting their slender grey trunks against the deep green of the fir-trees which bear them company. On the topmost bough of one of them a great blue heron has just alighted. What a grotesque fellow does he appear as, balancing himself with his huge wings, he clutches the slender perch with his big strong toes and claws! Those beeches are as dead as can be. Some years ago the herons nested in the branches, but the onslaughts of prejudiced keepers ousted them, and they have elsewhere started their heronry. That fellow yonder, with his beautiful 'apron,' is in magnificent plumage. He has simply come to take a passing survey; and will make up his mind, as he did last year, that to build here his home will be useless. With a harsh 'Frank!' he takes to wing and winnows his way to some ditches where the frogs are making amorous 

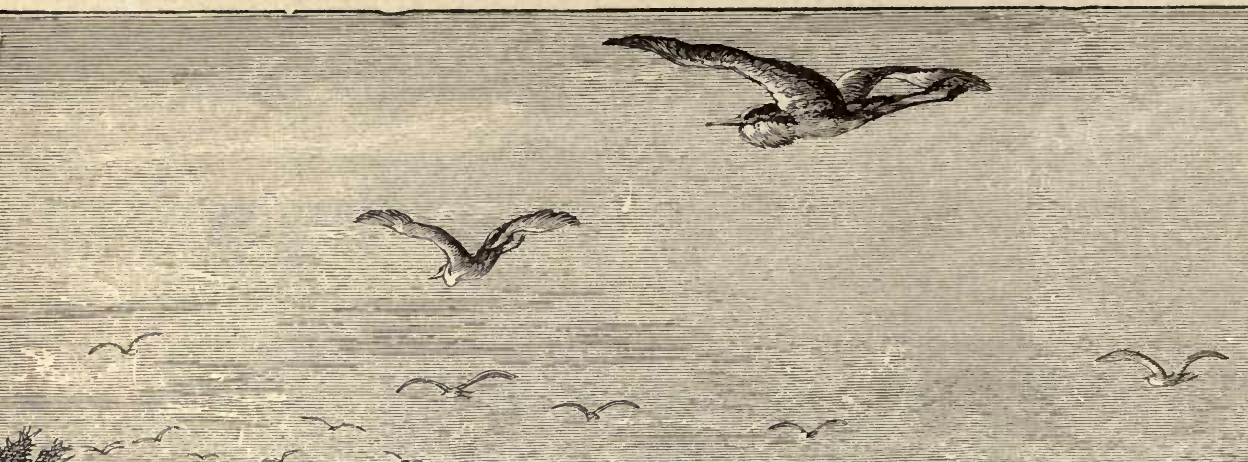

7)

3
3

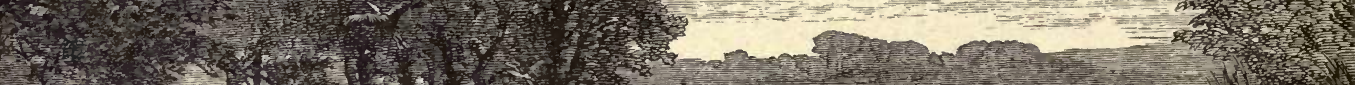
H.

(1)

1.

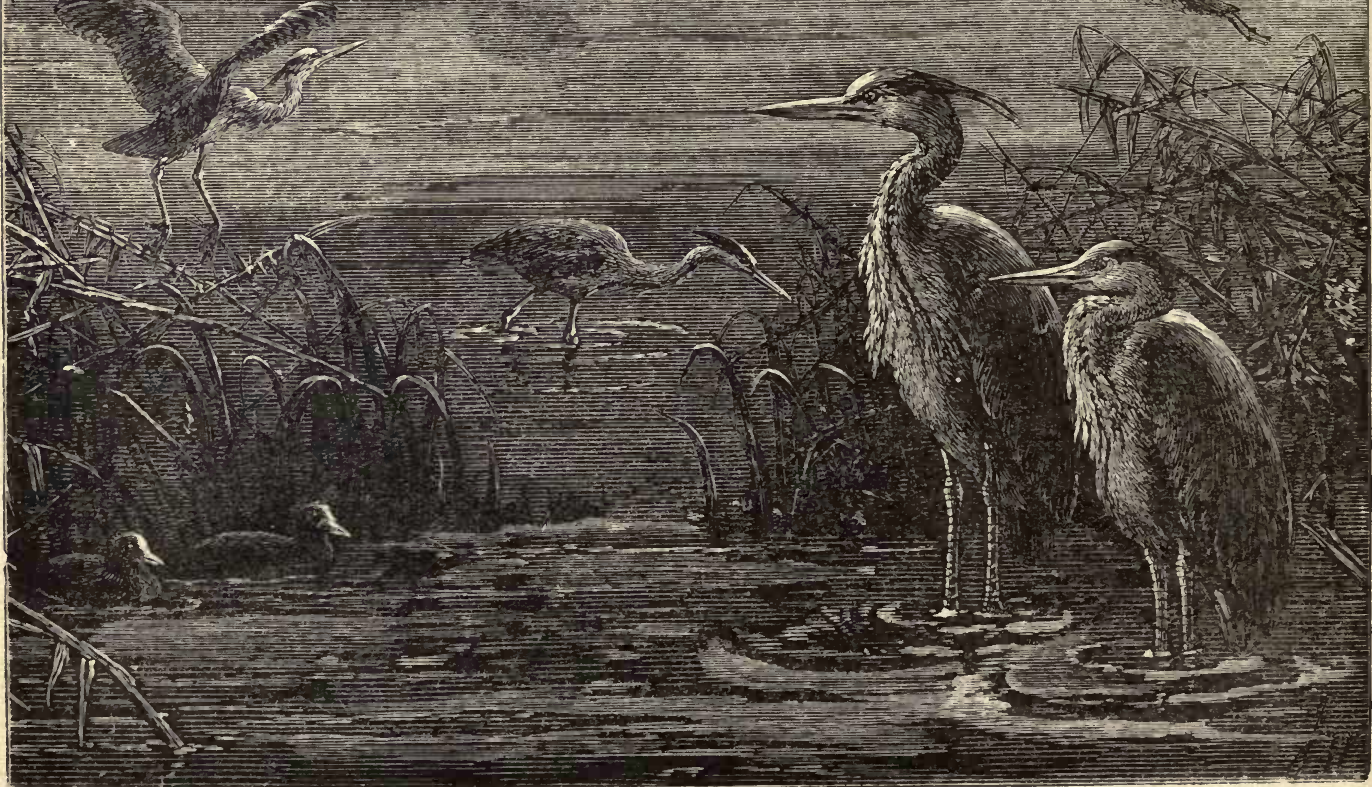


gossip, or perhaps to a 'beck' where the little rudd or roach are enjoying the sunny warmth of the shallows. Failing these, the wakened newts or silvery sticklebacks will suit him just as well.

We have tired of our survey, and again ply the oars. Hearken to the merry carol of the lark! Those feebler but sweeter notes are the love-ditty of the blackcap.-Splash! A greenheaded mallard, followed by his plain, brown wife, startled by the crackling of the reeds as our oar crashed in amongst them, flies up from a narrow weedless pool in the midst of the reed-bed. What a grand fellow he looks as he overtops the reeds! Without a doubt, somewhere in the herbage beneath the distorted branches of those dwarfed sallows, a nestful of pale green eggs is snugly covered. Those straggling curled leaves are the advance guard of the water lilies. We must drop in here again in the summer days when the fullspread leaves are crowding the placid waters, and the beautiful white flowers are resting upon the surface, and when the blue and yellow iris will be reproducing their bright tints in their reflected shadows. Those pure white swans yonder are contemplating nesting. Yon anglers are busy among the scaly inhabitants of the Broad. We will not disturb them.

The swallows have been dashing here and there all day, and the plainer sand-martins have been seen in goodly numbers. They seem to find enough to do among the awakening insects, especially those which delight to dance in sportive groups around and above the shooting broad-plants. They tell us of sunnier days in store.

Let us steer into the narrow sluice which runs apparently close to the Broadmargin. Landing on a low-lying boggy spot, we throw our painter round the bole of a willow, and daintily pick our way along a sinuous path, the swampy soil sinking beneath our tread. We must keep on moving or we shall come to grief in the quaking bog. Place your feet upon the grassy tussocks. The sedge-birds' notes are heard on every side. One anxious pair fussily fly around us, wishing us, no doubt, begone. Titlarks twit-twit overhead. Here we are upon terra firma. At our feet stretches a well-weeded ditch, bright with the yellow kingcups; great sprawling toads are clambering over and among the watercress, trailing their long gelatinous strings of ova; and a pair of yellow wagtails, in their resplendent golden of springtime, are searching for the larvæ of insects. Here is an old willow-stump covered with small-leaved ivy. The sallows around us are adorned with woolly buds, among which great humble-bees drone and gossip. Yonder lapwings have laid their brown-speckled eggs in the furrow; and those wood-pigeons, making their way across the meadow, have already built their nests. Far away stretch 
fertile fields, the wooded hills beyond them forming an abrupt horizon. Here and there some grey and ivy-mantled church-tower marks the site of a village, the red-tiled houses of which peer out from among the trees that guard it.

Our horse's hoofs are once more smiting the road which trends towards the smoky town. A small brick bridge spans the tributary

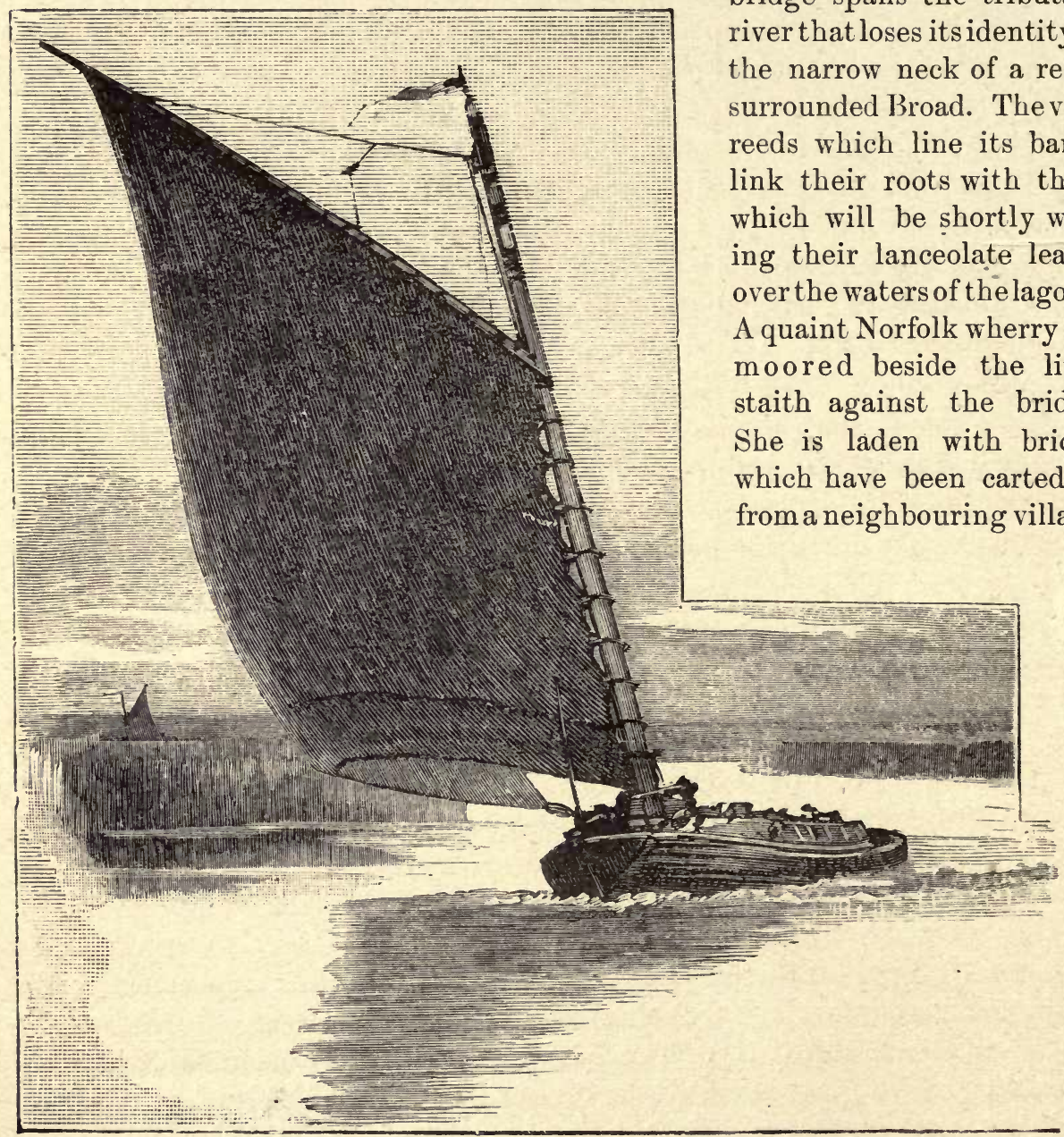

A NORFOLK WHERRY. 
A towy-headed wherryman, 'topped' with a red wool cap, makes a clumsy bow and wishes us good-day. There is a refreshing smell of tea emanating from the cabin door, and a curl of faint blue smoke is issuing from the red wooden chimney.

'Oan't yow hev a cup of tea?' the good-humoured skipper queries, for he is a quondam friend of ours. We acquiesce, and jumping down we deliver the reins into the hands of his ' mate,' who has been sent ashore on purpose.

Was ever such a quaint and picturesque craft? The schuits of Holland are not more in keeping with lowland scenery.

'I know yow like my old wherry-Topsy, you've told me so afore. Wal, she's as rakish a craft as ever heeled to wind'ard, an' she'll sail as close to the wind as any mortal thing afloat. I'm proud on her, and kape her as spick-and-span as mop an' paint-brush'll make her. A heap of them London chaps have took her picture, some with them likeness-fakers, and more 'an one ha' daubed her on a canvas. They say, 'bör, as how there ain't our sort of wherry found nowhere else in England. She's a bard of the broadland waters, sure-ly! Wall, yer see, she's built for lokel waters, and for lokel requirements. My craft, yow know, is my livin' as well as my hobby. She's fifty fut in length, with a beam of twelve, and scarcely draws three fut of water, an' 'll carry thirty tons. Except this cabin, she's one long hold-the length of her. I don't suppose yow'll find any other craft with such a big sail for her size as a Norfolk wherry. Yow was amused, I know, with the for'ardness of the mast. But, yer see, it's nicely balanced by that ton-an'-a-quarter of lead on its heel.

'That windlass runs it up an' lets it down, just as we may want to hist the sail or lower the mast to get benean a bridge. That little flag atop is a famous telltale, for it's the slightest puff as is wanted to show the way the wind goes. When winds are fair we spin along like lightnin', and when they're contrariwise we hev to tack, in course. And should they fail us altogether, we simply hev to stick down the 'quant' and, clappin' the shoulder agin it, walk the plank an' shove her along. Twenty mile of that will make yer cough! But for us many of the willages jindin' the rivers would find freightage rather awk'ard. But lor, sir, wherryin's nothin' near what it wor, for the railways have cut it up most awful. Still, as they doan't run everywhere, and as we can bate them on the score of chapeness, we shan't die out, us wherrymen, as yet. There's sights as oan't cum up to a fleet of wherries a startin' from Yarmouth on the early flood; some carryin' general cargoes, others corn, and others timber. It's a fine sight is seein' them cuttin' acrost old Breydon. 
'So yow like my little cabin; wal, 'bor, there's many a wus box 'an this to sleep in, leastways, I sleep, and my. mate-he snores fit to bust up the hatchways. We're bachelors here, my mate an' me, you know, for his'n old woman lives up in the town, and mine's fixed up in the village seven mile from here. We've got all the odds an' ends for cookin' an' comfort as we want. Jim ken make a puddin' or a dumplin'-leastways he makes pretence at 'em, an' if you ken call a ball of wax inside, kivered with a inch of sloppiness, he ken make 'em, an' no mistake. An' what duke cud lie snugger 'an we do at night-time on these ere benches, with proper toggeries to make 'em soft an' keep us warm?

'An' my tea ain't bad, 'bor, for the leaves wor left in from Monday, and this is Friday. Stop a minnit, let me take that bit of 'baccy off as is floatin' in yer cup; I'spect that's an old quid as dropped off the mantel-shelf! Now I'll just put the pot aside on the hob for 'Smiler,' that's my mate, yow know. An' now for a pipe o' baccy afore yow go, 'bor.'

A friendly gossip follows, in which the birds and beasties, and various items that delight a Broadland Naturalist are discussed with mutual relish, but which space forbids to detail. Two hours later Boxer is munching his hay in the stable at home, and a savoury bloater, fresh down from the ' loves,' is engrossing our own attentions.

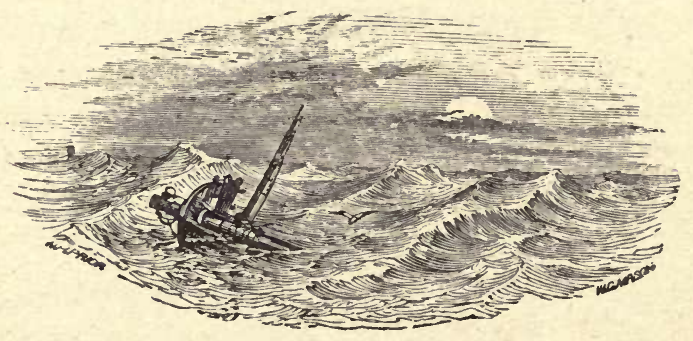




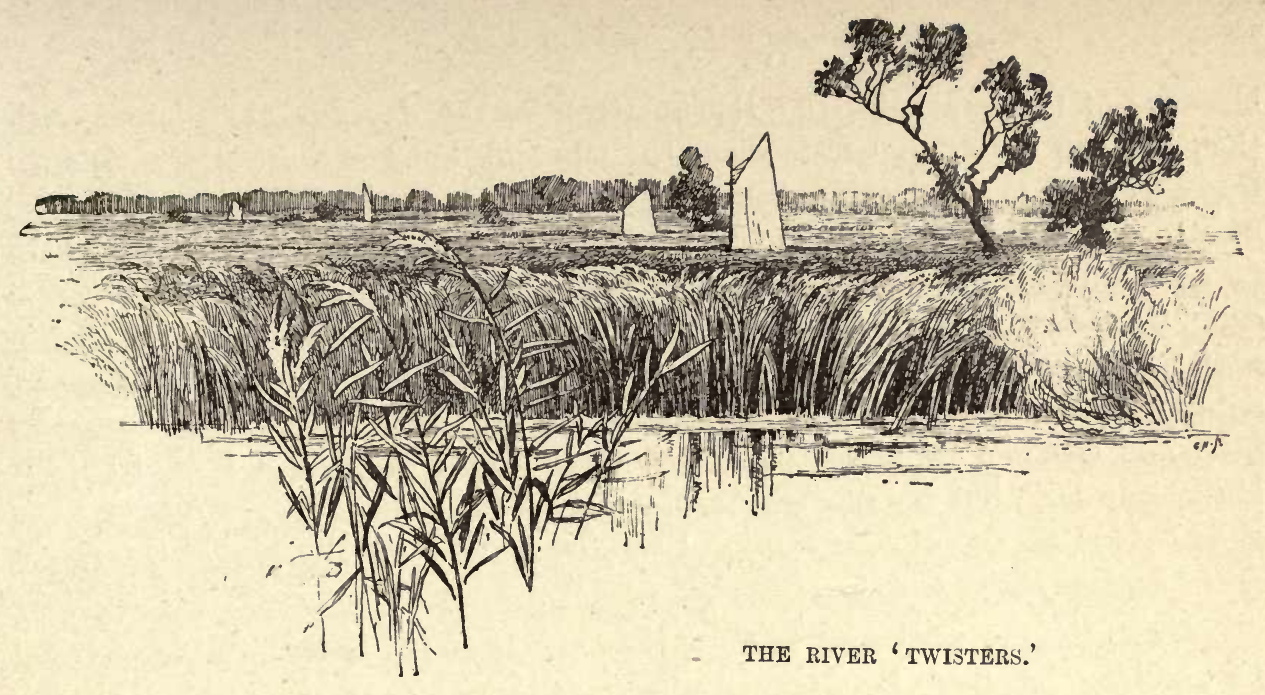

\section{MAY IN BROADLAND.}

'Humble race of men, Alike amphibious, by kind nature's hand Form'd to exist on water and on land.'

-Life of a Fenman, 1771.

HE river Yare runs its enormous torrent of dull brown waters, on a sluggish ebb, into the German Ocean. The streams which focus themselves at Breydon, a huge backwater 2,000 acres in extent, are three: the Yare (by some still named the Wensum), which trails its sinuous stream through Norwich and Marshland, continuing its course to the sea; the Bure, draining North-east Norfolk; and the Waveney, that divides the county from its neighbour, Suffolk. These, with some smaller tributaries, drain some fourteen hundred square miles of country. Excepting only three or four, all the great freshwater lagoons, now so well known as 'The Norfolk Broads,' are connected with these rivers; they cover nearly 5,000 acres, the rivers offering nearly 200 miles of navigable waterways. Here's El Dorado, indeed, for the yachtsman, the naturalist, and the tourist! And to-day we will reach the Broads by water.

Smiling May has burst upon us amid the merry music of birds, and clad in a vesture of many-tinted greens. The hedgerows are bright with the white scented 
blossoms of the hawthorn, the thorny stems of the dog-rose are adorned with the pale pink petals, and festoons of the climbing honeysuckle fill the air with fragrance. Here the droning bees delight to work, and the light-winged butterflies to dance and coquet. Cowslips dot the meadows, but in many places are far out-numbered by the yellow crowfoot, which children delight to call the buttercup. On the hedge banks the azure-blue flowers of the germander are conspicuous, whilst hard by the milkwort is pushing up its pink blossoms, and the humbler red-nettle bears them company. Birds are singing their sweetest love-songs in bush and tree and hedgerow, and above them soars the plainest bird of all, the blithesome lark, but never a one can outdo him at a roundelay. A bright and almost cloudless day of clear shining tinges all nature with sunshine. Our spirits are in harmony with our surroundings.

On such a day as this we would make our way to the Broads. It is early yet for yachting, but more than one 'white-winged' craft shows its great glistening sails above the lowlands that stretch away north and westwards from the town. Those dark brown sails, which seem to rise out of the very marshes and glide this way and that, denote the progress of the quaint Norfolk wherries along the course of the serpentine Bure. Some friends of ours are about to indulge in a day's outing upon the river, and we have accepted their invitation to bear them company as far as they choose to ferry us. Thence we hope to boat our way across one of the largest of the Broads, and return by rail.

Behold us bowling along under all canvas, the bonnie Lapwing cleaving her way in gallant style through the rippling waters, the steady breeze pressing her onward. Splendid boats are these Norfolk yachts, spreading plenty of canvas, with tall, tapering masts, long gaffs, and longer bow-sprits, with plenty of counter, very little keel, and enormous rudders. They are easy to handle, and in experienced hands are a thing of beauty and a joy for__ as long as the breeze holds good. But the bends of the river, as the stream winds its circuitous course, keep the man at the tiller busy, for now we have to get upon this tack and then upon the other.

How bewilderingly the river 'twisters;' we seem from time to time to be heading for every point of the compass; now we're on our starboard, then our port side, now beating up to wind'ard, then off we go again, spinning along so gaily, our great sails bellying to the wind - then we tack again, the canvas fluttering like the wing of some seabird shaking off the spray, until we catch the breeze again, and off we go upon the other tack. But how jolly and exhilarating! What a sense of buoyancy and freedom we feel, unfettered for awhile from the conventionalities and the restraints of society and of business! 


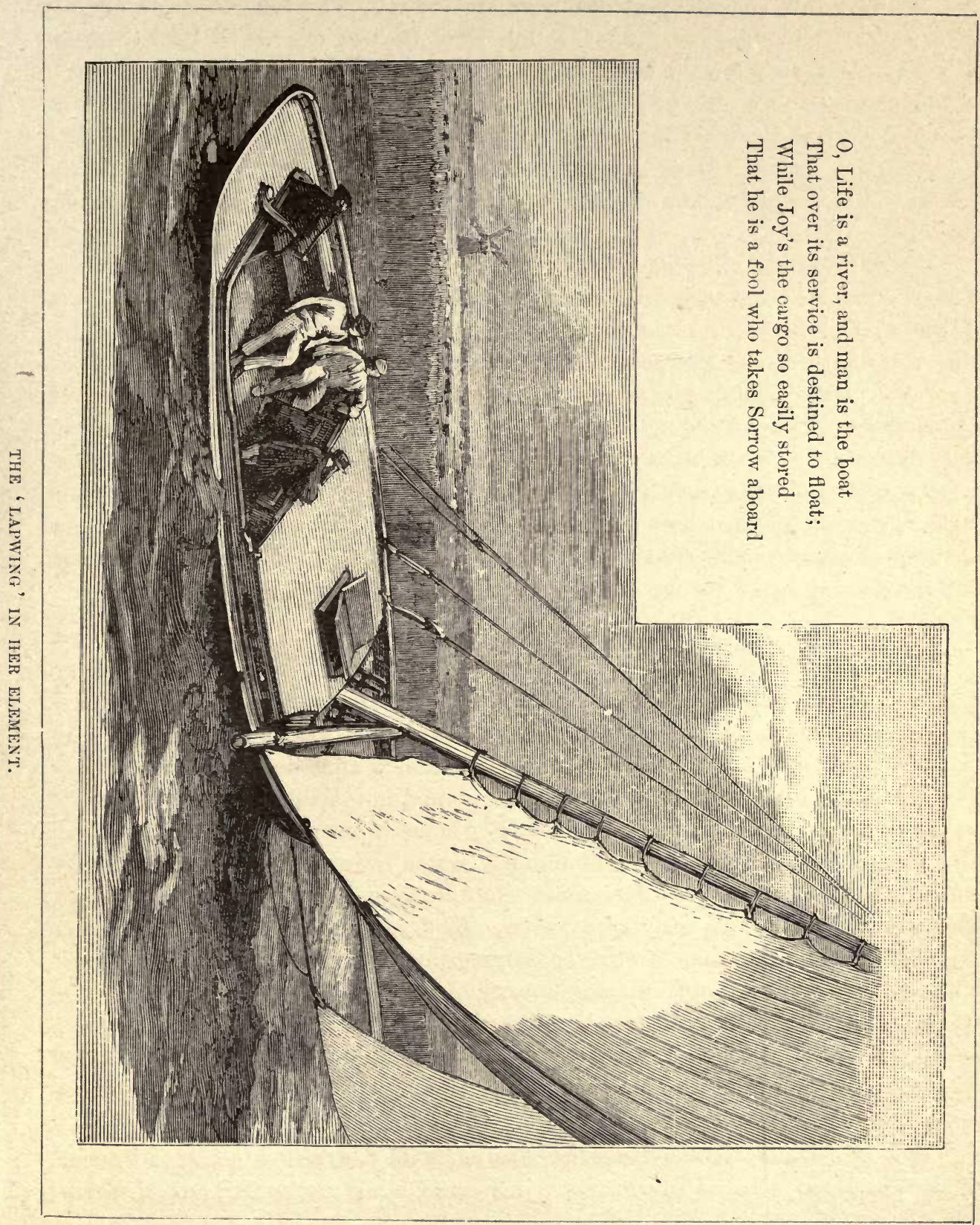


We have left the many-gabled town behind us. The lower reaches of the river are flat and uninteresting, the dull level beyond the river banks being relieved here and there only by some grim old pump mill, some marshman's lowbuilt homestead, or a stile of gnarly timbers, against which sleek cattle rub their sides and chew the cud. The marshes are alive with cattle. Now we pass a deeplyladen wherry, with the skipper, quant at shoulder, shoving her round to catch the breeze, whilst the mate, who mayhap is the good man's 'missus,' is leaning against the tiller.

On we glide past riverside villages, with their windmills and ferries and clumps of trees-the monotonously dull, flat scenery which, they tell us, savours so much of that which is Dutch. From Stokesby onward the aspect changes for the better, and pretty little nooks and corners, that many an artist has reproduced on canvas, loom into view. Shooting through Acle bridge with lowered mast, we hoist sail again, and still keep bowling along up the Bure until we reach Thurne mouth, then on again up this tributary, past a picturesque half-barn, half-farmhouse, upon which a clump of trees cast their shadows, and then past Womack Dyke, until we reach Potter Heigham, where we moor. Here, after a jolly luncheon at the famous hostelry which overlooks the river, we bid adieu to our yachting friends, who are bent on making again for the Bure and sailing still further northwards.

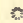

Gliding along over the clear shallow waters, margined by the yet short young reeds of the year, above which the leafless, tottering stems of an older growth are drooping and fast going to decay, we make for the open Broad. Splashing noises in amongst them tell us that a shoal of bright-finned rudd are not far away from us. We are not provided with tackle or we should not be able to resist the temptation to throw them a baited hook. We fling in a few bread-crumbs, however, and after them dash the bold, handsome finners. Rudd love these quiet waters, undisturbed as they are by rapid tides, where the tall reeds nod above sheltered pools. They are sociable fellows with their species. Mayhap they are seeking a spawningground, for they shed their ova in the early spring-time. A splash hard by, as of a huge dog flinging himself into the water, is followed by a speedy dispersal of the shoal. Look ! didn't you see that long-jawed head of a pike rise above the surface, holding between his shark-like teeth one of the luckless fishes? With a swirl of his big forked tail, he is far below and is off to his snug lair, known only to himself, to devour his victim at his leisure.

Yonder Noah's-ark-like structure, moored beside the reeded 'rond,' is the hut of an eel-catcher. In the stern-sheets, just outside his cabin-door, sits the occu- 
pant, munching his noontide meal. He is a 'character' in his little way; and it will repay us to get to wind'ard of him, and edge him into a gossip. He wishes us ' the seal o' the day,' for your native, gruff as he may be, has a share of inbred politeness. Our boat glides between some curiously perforated boxes, which float round his strange houseboat, and 'crowds' her stem into the wall of rushes at the river-margin. A savoury aroma emanates from the cabin, an odour of fried eggs and bacon, and bacon it is which lies spread upon the old man's platter. A big bit of the earthenware has been chipped off it, but sufficient space remains to con-

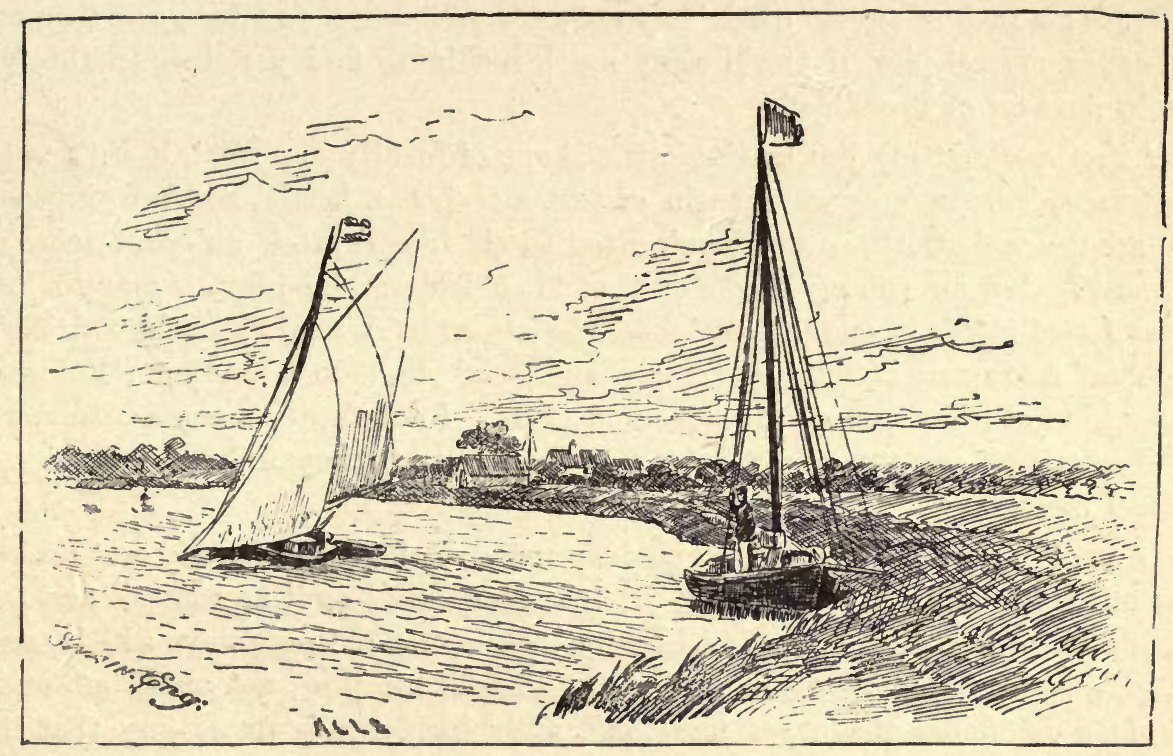

ACLE ON THE BURE.

tain the huge slice of what was once part of an aged porker-if guessing may be reckoned trustworthy; and it is so fat that few besides an eel-man's stomach could bear the infliction of digesting it. He sits awhile in silence with the plate upon his knees, but keeps on 'champing' with his remaining tooth-stumps. They are on special duty this morning. After a little preamble, a desultory conversation is kept up upon birds and fishes - such as share the wild watery wastes with him, for he has been knowingly reckoning us up with those small grey eyes of his; and we find him not only full of information, but exceedingly communicative. Dinner meanwhile comes to an end, and leaning over the stern of his vessel he rinses his 
plate and sundries in the clear waters which float him; then tossing off a mug of something that presumably is tea, although it looks uncommonly like liquid blacking, from long standing in the teapot with half a spout upon it, he steps back into the ark and invites us inside for a continuance of our confab.

' This ain't the sort of shanty yew gents are used tu, but they suits us folks as they're built for up to the knocker. I doan't suppose yow'd find theer likes out $o^{\prime}$ the county. We look up an owd smack's boat, bodge her up a bit, then rig her up with a ruf, an' surroundin's, an' tars 'em-an' theer yow are, 'bor-as nobby a craft as yow'll find afloat. These 'ere benches as we're sittin' on sarve for bedsteads; a sack of sweet 'mesh 'hay an' a blanket or tew to tuck yerself in, and I'll swaller my eel-pick if yow'll want much rockin' to find yer sleep in this 'ere strong, pure air of Broadland.'

' Yow smile at my jim cracks in the shape of furniture. Wal, it ain't much as we want, 'bor - a mug an' a basin or tew, a teapot, a kettle, and a frying-pan, with a knife an' a fork, so we doan't need to eat like Injuns - an' what more du yer want? Let me rub my sleeve on that bit o' lookin' glass, for it's many a long day as I seed inside it, and the smoke an' the steam ha' kinder dullened it. We're rough an' riddy sort of folks, yer know, and livin' out here a lonesome Robinson Cruzer kind of life wipes all the polish off of us. I doan't hev many wisitors, and a owd man ain't many fancies; an' if folk doan't like it they ain't obliged to stop, not as I means yow, gintlemen.'

A short clay pipe is found in the deep recesses of one of his waistcoat pockets after much fumbling in its corners. It is harder work - so it appears, to find that with which to load it. There is a hungry look in the old man's eye which seems to ask for-'‘bacca!' We hand him enough to fill his pipe, not once, but often. The deep old fellow thaws yet more, and after incidentally remarking that 'it's a tew-mile row to get a smoke when baccy ha' got to low-water,' he resumes his patter:

'What's them holey boxes outside for ? Them's eel-trunks. Yow doan't need, in course, to ax me what's my profession, of course yer doan't, for arf an eye's enough to tell it. Boy an' man, like my father afore me, eel-catchin' an' a few other oddments has got me my livin' these fifty yeer an' more, and it's a mod'rate livin' at most. But I get enuf to eat, an' pay my way, keepin' the old woman's cupboard at home well filled-and what more $d u$ a fellow want, only to be thankful to our hivenly Father as give him strength an' helth tu appreciate 'em. Babbin's mostly my business jest now, and will be till the summer's over an' forgotten, and the eels be makin' for the sea. Then we drop eel-sets in the river tu catch 'em when they're 
runnin! The eel-sets are suffin like a big trawl net, with the mouth athwart the river; into it the scrigglers swim, and down tu the poke end they wriggle. In course we take good care by manes of proper contrivances to puzzle 'em how tu git out agin. Dark, wet September nights are the best for this fishin', especially if a bit of thunder keeps a rumblin'. In a good season tons of eels are taken an' sent tu the London markets. Them cockneys dote, so they tell me, on 'em.'

'What's babbin' like, 'bor? Wal, I'll tell yow. It's as aisy as aisy if yer only knows how. Yow get some worams, as yow kin any damp night when they turn up on the grass tu 'mardle.' Yow want a lantern an' a tin, and yow want ter look lively, for they sune pop in agin. When yow want to 'bab' yow make a 'bab.' And this is how yow du it-I might as well show yer, for I shall be a babbin' tunight down hinder.'

Taking out a tin of lively worms, and finding up some thread and a needle, he begins impaling each unhappy victim, making quite a festoon of them. We try to watch the operation without a shudder: he evidently thinks he is putting the worms to very little inconvenience.

'Yow then bunch 'em up like so -' (winding them round his fingers) 'an' tie up in a knot, fix on yer sinker, an' theer yow are. Tie the lot on the end of yer line, bob it up an' down till you feel an eel a chuckin', then heave him up gently an' drop him in yer boat, which he'll $d u$, when his teeth git disintangled. We sumtimes catch tew or three stone a night. Sumtimes never a eel, 'bor. Them boxes outside we pop 'em intu, where they doan't seem wery uncomfortable, for the tide goes through 'em, 'cos they're riddled with holes; then when we want to sell 'em, there yow are, yer see!

'What about the winter? Wal, we go a-pickin' for sich eels as have buried theerselves in the mud, 'bor, for all doan't travel seawards. Here's a eel-pick.

'Eels is rum things-lor, they're as big a mystery as anything I knows on. Some say they grows from hoss-hairs: some say they've young 'ens-I doan't believe nayther. Why, I've seen under a magnifier what folks calls the fat of the eel, and it's no more nor less than eggs. The 'over' (ova), as a gent called it, don't grow wery big till the eels are in the deep seas-where they spawn, goodness only knows where; and where the old 'uns go after is just as big a wonder. Anyway, I've seed little totty eels not bigger nor darnin' needles, and yow can see through 'em, coming up the shallows from the sea in thousands in the springtime.

Much more eel-lore is dispensed, which space forbids to detail. As we are leaving the old man in his lonesome hut, to step into our boat, a kingfisher 
dashes off the end of an oar which has been lying akimbo, and with a startled scream is lost in a bend in the reed-bed. Some tiny scales sparkle upon the blade, which we examine more closely. The kingfisher, unnoticed by us and accustomed, perhaps, to the eel-babber's voice, had evidently been fishing from our oar-blade: here is certainly proof positive that he has had a little fish for dinner. Some coots that have waxed bold enough to venture out in the open, disappear as

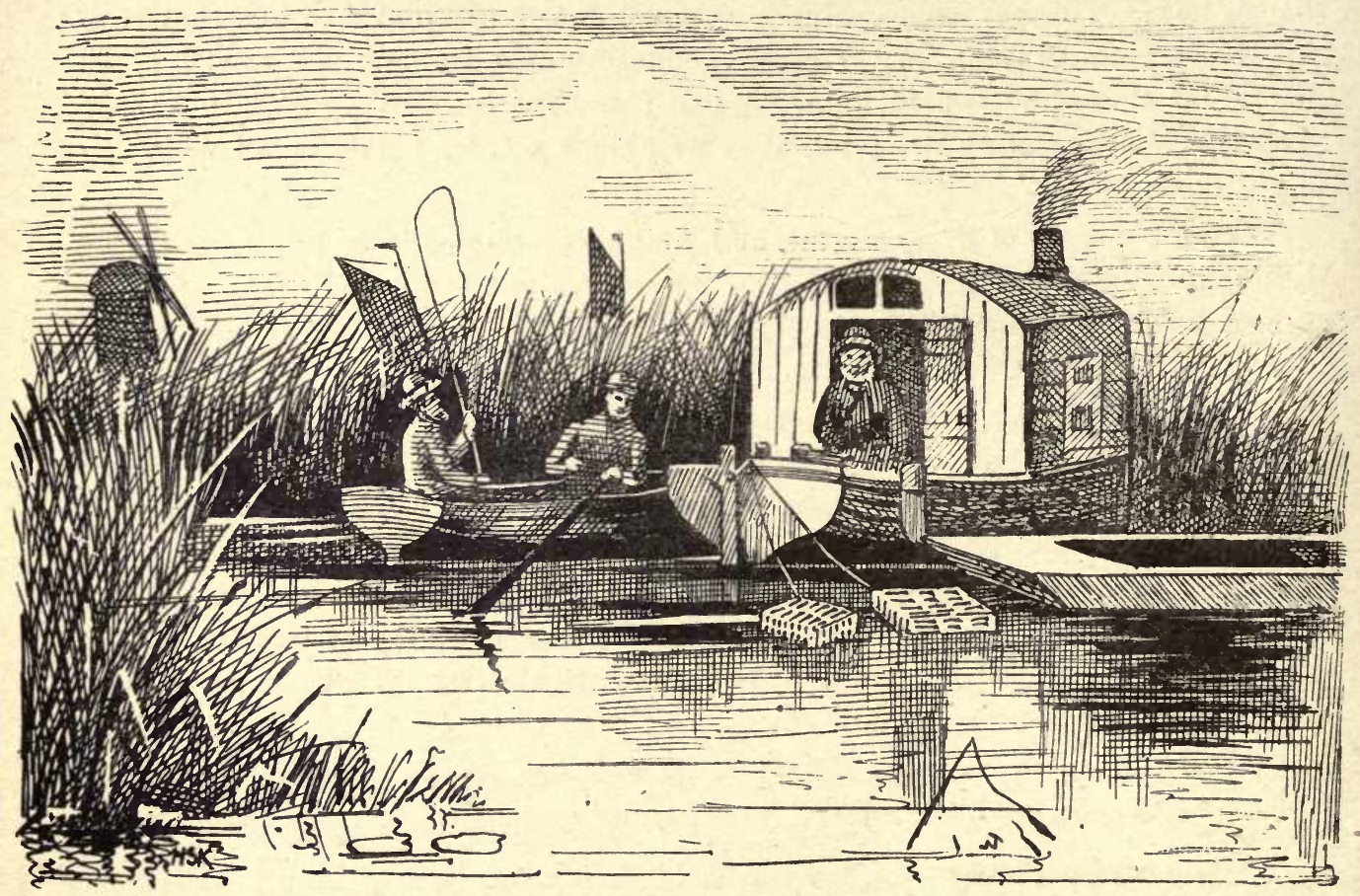

AN EEL-CATCHER'S HUT.

if by magic, and a couple of red-billed moorhens dash off with more precipitancy than caution, trailing their feet in the water as they widen the distance between us. Yonder flies a heron. Let us row for the far side of the Broad. But for the sounds of bird-life, the quietude would become oppressive, such strange music is borne on the wings of the wind-harsh wild cries, jarring notes, and the sweeter sounds of bird-song. It is the season of love. Each little songster is vying with its fellows in making cheerful harmony. Even the rooks in the tall trees yonder 
seem to think their efforts praiseworthy. But they are appropriate to the scenery around, as are the harsh notes of the grebes and waterfowl. The reed-bunting and the sedgewarbler, and many another of their kindred from over-sea are present with us; some are flitting in among the branches of the trees which border the mossy swamps that margin the Broad, others are busy in among the remnant of reed-stems seeking a location for safe nesting. Many are already engrossed with the cares of domestic life.

We pull round a bend in the interminable reed-bed, and find ourselves in a quiet corner of the Broad. It is a veritable little 'straits,' connecting this one with another. Willows are reflecting their pointed leaves in its depths, reeds and sedges in its sunny recesses are growing more luxuriantly than in the open Broad. A ricketty foot-bridge spans the farther end and on it is sitting a hawk-like bird, which presently takes to flight. Its ringing notes betray its identity; it is a cuckoo. Some lapwings pass overhead: they are nesting in an adjacent meadow.

Hush ! do you not see that big brown creature sitting beside a bank on a boulder of grass-fringed soil that has broken away from it? It is an otter. Gently! Just peep at him through these glasses. He is busy at dinner: that fish he appears enjoying so much is undoubtedly a tench. The otter knows where good fish and quietude are to be had. There now-he has spied us, and with the slightest effort, and without a splash, he has dived into the water, and will not come up until he has reached his lair in some rush-covered corner. House-martins and swallows are dashing to and fro, as they have been all day long. Here they appear to be especially busy, for many a lace-winged fly is taking its earliest springtime airing; and larvæ cases floating upon the surface of the water are familiar objects to the lynxeyed naturalist. There is a shoal of small gudgeon; they are feasting merrily upon heedless little insects which appear to delight in touching the water in their joyous play: gnats and midges are among the number. There goes, high overhead, a swift-and another. Hearken to their wild screaming!

Don't you see that moorhen peering out from behind that willow bole? He has a nest somewhere close by it, let us paddle up and see if we can find it. The cunning thing has vanished, but here is its inartificial nest: it is made of reedflags and sedges matted together. Nine buffish-white eggs dotted with red-brown contain the fondest hopes of most attentive parents. A faint peepy cry emanates from among them. Why! one egg is chipping, and a tiny pair of red mandibles are poking their way into a world of trouble. If half of those black downy chicks, which will soon be demanding incessant care and attention, escape the onslaughts of pike and a host of other enemies, they will do well. 
We may not loiter to inspect the swamp where the white swans are nestingif we do we shall not be welcomed by them - nor hunt for a great grebe's floating egg-basket. Much that we see and do must remain unknown, save by ourselves, for our space forbids it. We could linger yet, but the time has sped, and our watches are pointing well towards train-time.

Behold us at eventide, in the middle of May, sculling in a gun-punt up Breydon, making for one of the 'drains' which at low-water vein its muddy breast. The tide is rising, and the 'flats' by the hundred acres are disappearing below the flood. Here and there the 'lumps,' still dry and uncovered, are gradually growing less in area. Strange whistles and call-notes are heard as many a long-legged wading bird is ousted from its feeding ground and compelled to seek a drier location, for when too deep for walking it must needs swim or flit-which latter it prefers to do.

The spring migration has set in, and many a northward-bound bird drops in upon us, amongst them the whimbrel, knot, and dunlin, the turnstone, grey plover, and pigmy-curlew, and many another. These, attracted by so fine a feedingground, drop in awhile and refresh themselves, and proceed upon their journey. Many a rarer bird, attired in its springtime best, mingles with the commoner herd. But close-time has thrown its protecting clauses around them, and they remain unmolested by the gunner who envies them their jackets. The bird-stuffer now loses his richest plumaged specimens. There was no close season until well into the 70 's.

Let us draw to the highest of the 'lumps:' all else is covered with the water. Here the birds are making their last stand prior to betaking themselves to the marshes, the sea-shore, or still farther away. What a medley of notes, and what a concourse of birds are before us! There runs a turnstone-there are six of them at least. Those mellow call-notes denote the presence of several ringplovers, and their black gorgets also betray them. Grey plovers, some curlews, dunlins, and others are also identified. What sooty long-winged birds are they which now dropped in at the water's edge? They are black terns, and the species once nested in Broadland. And those pearly-backed, swallow-like sea-birds with them are Arctic terns. They are tame enough, poor things; what havoc a gunner might make in their serried ranks! Day after day, till the month is out, will such birds be seen if the winds blow fair-from the east at any point. With westerly winds continuously blowing fewer and fewer birds will put in an appearance. $\mathrm{He}$ is a lucky man who chance-time sees here the beautiful avocet, the quainter spoonbill, and the lordly stork. The day is spent; darkness covers all, and nothing now denotes the presence of the birds but their weird wild notes. 


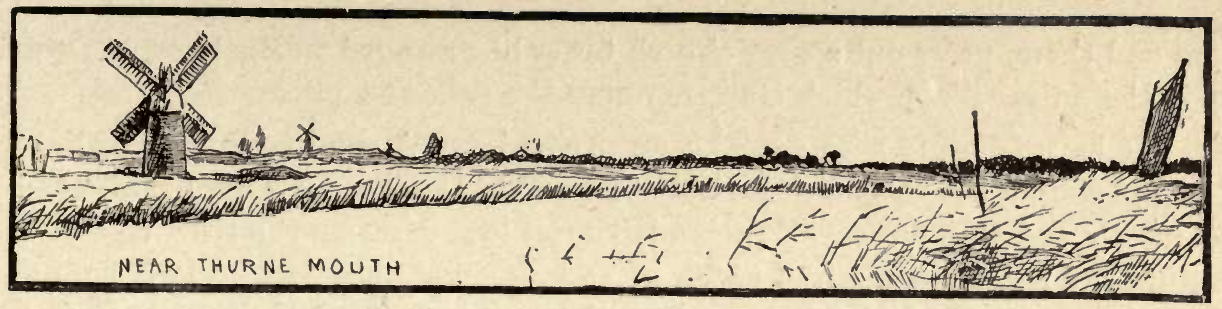

\section{JUNE IN BROADLAND.}

'And the wavy swell of the soughing reeds, And the wave-worn horns of the echoing bank, And the silvery marsh flowers that throng The desolate creeks and pools among, Were flooded over with eddying song.

AYEST of the months of the year, smiling June dawns upon us garlanded with roses; the fields and woods and hedges are glowing with the warm touch of her fingers, and all nature seems joyous and light-hearted. There is the slightest ripple upon the surface of old ocean, and a faint murmur falls on the ear as the tiny wavelets 'crowd' each other, as if in play, upon the shingly shore.

In Broadland there is quietude, save as the birds make merry music, and the lowing kine join in with deeper bass, and the bleating of sheep is heard-or save when the playful wind whispers in the tree-tops, that here and there fling their shadows upon the placid waters below, and it bustles up and down the crowded ranks of pale green reeds until from among their leafy stems, waving and rustling, arises a murmur that reminds us of the gentle plashing of the wavelets upon the sea-beach.

On such a morning we find ourselves at the railway station securing tickets for a jolly day's outing in Broadland. Ere long we are being borne through furzy and bracken-covered sand-hills, beyond the valleys of which are caught glimpses of the deep blue sea-now across fields where the dark green corn is growing, sometimes shut in for a brief space by trees and tall hedgerows, but more often rumbling along in the open, with miles and miles of landscape stretching away on either side of us, with the distance softened off into foliage, from among which, 
here and there, peers out a grey church tower like an aged sentinel keeping watch upon the quiet village which clusters round the hallowed pile.

We have fallen in with genial company to-day. A genuine Broadland Naturalist has chosen the same compartment; he is bent on a day's hard work among the insects and wild flowers (if such a labour of love deserves the title, and for the capture and accommodation of which he appears amply provided), which buzz and bloom in the fens and wildnesses of Broadland. He is certainly a character in his

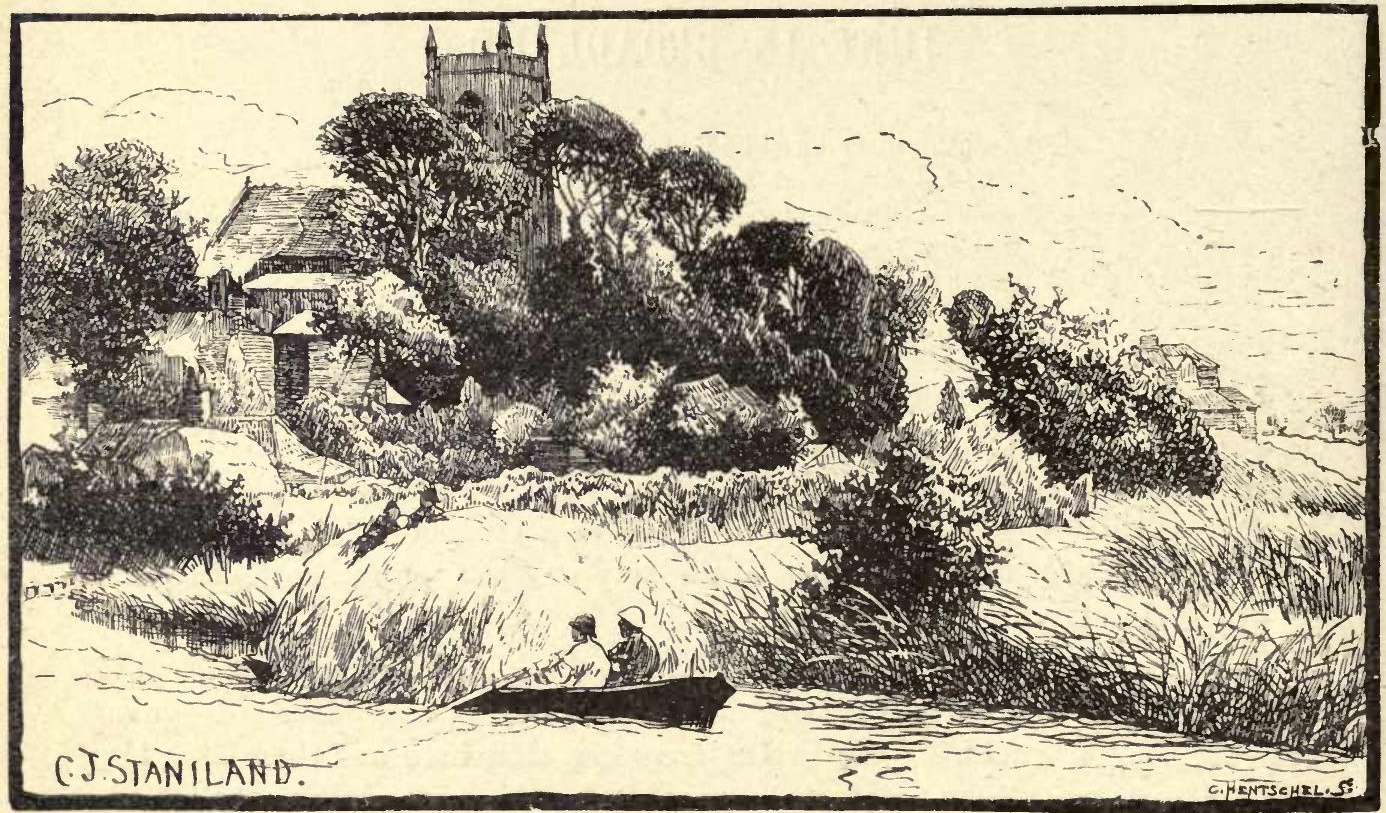

THE CHURCH AMONG THE TREES.

way, a small spare-built man, past the middle of life, with shoulders bent and betokening that some sedentary occupation has for long been his lot in life, and years of hard honest toil have made his large hands gaunt and bony. We are not long edging him into a pleasant confab, and the hard lines upon his intelligent face relax somewhat as he instinctively feels himself in company with kindred spirits. $\mathrm{He}$ waxes eloquent upon the delights of Broadland.

' You may have your rugged awe-inspiring mountain scenery, your wild rocky fastnesses if you choose, not that I have ever been amongst them, except in books 
of travel, but I can pretty well reckon what they'd be like; but give me my lowlying, marsh-covered, reedy Broadland, where the redshank, the coot, the grebe, and the lapwing ring out their strange weird cries. The land of the bullrush and the water-lily has delights for me that I am positive no other could possess.

'These fifty years have I spent, boy and man, amongst snips of leather; lasts and lapstone were my toys in childhood, and they get me my living now. Thump! thump! thump! Snobbing is dull monotonous labour, to be sure, from morning to night, with the smell of leather beneath your olfactories; but a man must live by the sweat of his brow. But then, sir, when one does manage to get his leg loose from the boot-strap, and let it and the other stride and scamper out in the open country on such a day as this, why, how much lighter becomes the burden of life, and what a pleasant little oasis in its dreary routine, to be sure it is ! - not that I am unhappy or discontented, by any means, for the fruits of many a jaunt in Broadland surround me when at my labour, in the shape of well-preserved specimens, which stir up many a pleasant recollection of sunny days and jolly doings among the flowers and insects, the birds and molluses, in times gone by. To accomplish much real work as a naturalist, a man needs to be above the necessity of earning his daily bread, and the time should be his own; but then, sir, there's this about it, when one's destined to earn his livelihood by close, hard, grinding labour, because fortune failed to smile upon his predecessors, he cannot afford to quarrel with her. Labour! well, one has got used to it by this time, without the comfort or inconvenience of having grown any the richer, for competency is not won, you know, by snobbing; but there's this to be said of it, its more a matter of hand than head-work. You can sit and thump, and think and thump, and plan and meditate between them to your heart's content, which can't be said of every occupation. It comes hard where a man hasn't a hobby, or any mental employment, and nothing to anticipate in event of a holiday, then the humdrum becomes a bore. That's why so many of my fraternity grumble about life's monotony over their pipe and pot, and engender discontent against their fellow-men and the good God above us all, who never destined man, I am quite convinced, to be unhappy, whatever sphere of life He placed him in. Sir, there is dignity in labour.'

Such is a sample of the interesting chat our loquacious friend unreels, and we regret our paths diverge as we step out from the village platform. Whistling a merry song, away hies the little man with the nets and wallet-which contains his store-boxes and bottles, and the hundred other little knick-knacks that go to 
form a naturalist's outfit. It is well for him that his captures will be light, even if numerous, for the paraphernalia he carries is sufficient weight of itself.

The lanes are now in the zenith of their beauty-the humble-bee and his kindred, and a host of meadow-brown, tortoise-shell, and other butterflies dance and gossip and glean among the bright flowers which dot the hedgebanks and push out their gay petals from between the stouter growth that would obscure them in their quest of sunshine. There is a wealth of colouration on every hand; the yellow hawkweeds have opened their starry flowers, and are smiling in the scraggiest of places,

'Where sweet air stirs

The bluebells lightly, and where prickly furze-

Buds lavish gold.'

A hundred others lend their charms to make the countryside beautiful; above them all tower the sweet-scented honeysuckle, and the pale pink flowers of the dog-rose. The meadows beyond are made gay with sorrel, and many another familiar wild plant; while lazy bovines, wading amid luxuriant grasses, are enjoying their brief existence, eyeing yonder farmer, and the butcher's man in blue, without the slightest suspicion that their happy days are numbered.

The ditches are brimful of life, from sluggish tadpoles and flashing sticklebacks, down to the tiny Volvox and the unseen Rotifera and other animalculæ. Our naturalist has by this time, doubtless, filled some of his bottles with specimens, for we noted him groping and dredging at a ditchside soon after we parted company. This very dyke trends away Broadwards, and possesses in miniature many of the features which characterise those great lagoons. Here are some yellow water-lilies (Nuphar lutea), their small golden cups contrasting prettily with the dark ovate leaves from which they lift their heads; forget-me-nots are sprinkled along the edge of the crowding reeds, and taller irises, with spangles of yellow and blue, look down upon them, whilst above all nod and rustle the green spear-leaves of the reeds, and around them tiny insects sport and play to the profit of many a swallow and sandmartin that are dashing to and fro. A kingfisher hurries away from a willow-bole at our approach, the ruddy hues of his breast reflecting in the water below him, his emerald wing and tail-coverts appearing like streaks of burnished metal as he flies in a bee-line to some shady nook he knows of.

Some tiny black animals, too quickly for the eye to follow them, plunge into the still waters like so many stones. They are water-shrews - and are, of all our British mammalia, the most secretive in their ways and habits. We have not time to loiter longer or we would certainly try and steal a march upon them. We have 
noticed many a young bird of the year as we came along-for the first birds have been started off to earn a livelihood on their own account-little tits and larger finches, not nearly so brightly plumaged as they hope to be next springtime, dot the hedgerows, forage in the herbage below them, or fly on hasty wing hither and thither. Insects are swarming, and well it is they are so, or the insectivorous birds would go to roost hungry; and the seed-eaters are now revelling in plenty.

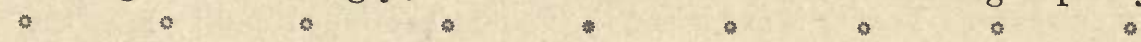

It is pleasant to glide softly on the rippling waters, scarce dipping the oars beneath the surface. The hum of life and the rustle of vegetation are soothing to

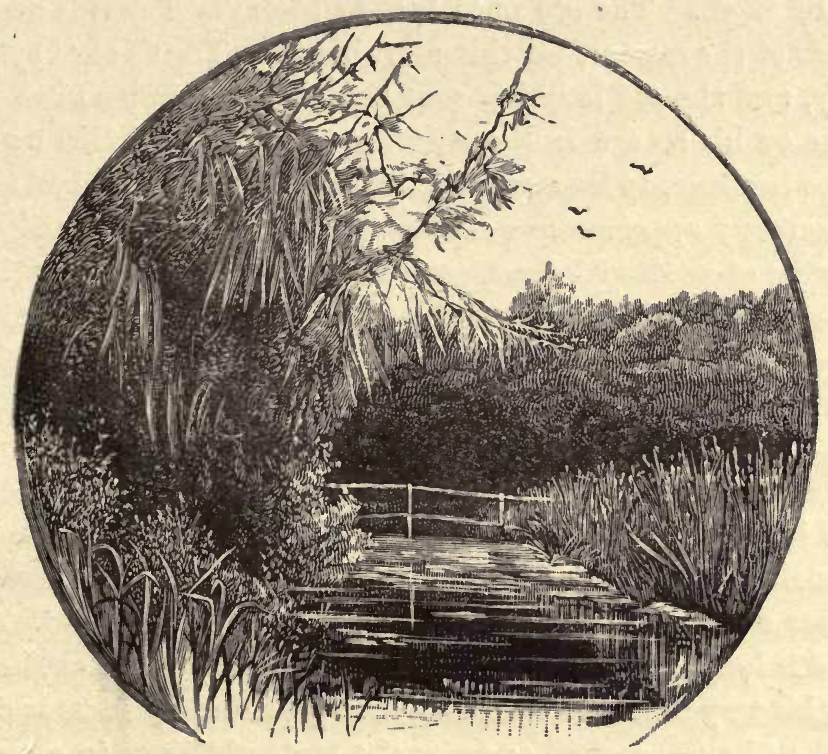

A QUIET CORNER.

the jaded toiler; a day's outing like this is rest and balm to both body and mind. Let the boat drift whither she will, we are not tied to any special 'doing' to-day. Not that we would kill time, but it is delightful to feel ourselves once more away from the worry and the bustle and the conventionalities of town life, and for the nonce to leave ledgers and hammers and scales and yard-sticks away in that chaos of brick and mortar where even the sparrows are sooty and the flowers and trees are dusty, and what little of nature is forced to breathe and grow in such uncongenial atmosphere seems pining for the purer air and sunlight of the country. 
There certainly is not much that is awe-inspiring in these great solitudes, and there is a strange sameness about them all; but they are lovely with a beauty peculiarly their own. Grand indeed are these great indented ovals of silvery water, apparently shut out from the rest of the busy workaday world by an interminable belt of reed and sedge and bulrush, and an environment of stunted woodland, where you might almost imagine dull care and the strife of life would scarce find a loophole for an entrance. Yonder is our friend the fenman's cottage standing upon the higher ground, with its fore-shore sloping to the water's edge in autumn; the trees on one side shake their leaves into it. Great white ducks are guarding their young broods in the sluice which trends towards the house, and several geese are cropping the grass near by them. The old punt is away to-day. Towards eventide we may expect the return of the master, for this morning Jem Trett's at 'haysel;' he is yet hale and hearty, and the old lady has something in the cupboard to which he will do ample justice on his return in the evening with his boat piled up with gladdon and other coarse herbage, to be used as litter in the pigsty, and bed for the ancient donkey whose scraggy appearance would suggest him to be as aged as his patron. Yonder is an artist at work with brush and maul-stick. Let us run the boat ashore and saunter towards him. A moorhen flutters out of the little reedbed as our oar sweeps through it; beneath, a shoal of small roach dash away in affright, all making for the open broad. Our friend of the easel is throwing on his canvas a delightful bit of scenery. In the foreground big broadleaved sedges dip their reflex in a pool of crystal, above them is a willow's drooping foliage, tall graceful reeds on the right lose themselves in the background in a cul-de-sac of alders, whilst a plank-bridge, with a rustic fencing, is thrown across the pool. A trio of black-headed gulls show up boldly against a bit of blue sky. Was ever such a lovely little corner-piece? Our artist friend is loud in the praises of Broadland. An aged man, bent with many years, wending his way from the fenman's cottage, sidles up to us and expresses his opinion upon the picture, as well as upon the state of things in general.

'Wal, 'bor, yow ha' done that ar' suffin proper. What nimble fingers some folk hev, tu be sure! I might ha' tried these seventy yeer an' more to ha' done that, an' cudden't,' says Jem Trett's elder brother, for the merest tyro of a physiognomist could have told his relationship to the old man of the fens.

'Ah! 'bor, these 'ere Broads,' he continues, ' aren't what they wor fifty yeer ago, not at all, they ain't like the same; not as the water is different, or the bards an' other critters ha' altered, although there's summat wrong with them, there ain't so many on 'em as there was by a wery long chalk. Talk of carryin' a gun nowadays, why, it ain't no use at all, but a waste of good powder an' time-time 
was when I wor a youngster, we cud du a bit of shootin'. In this wery neighbourhood I ha' put up five 'bottle-bumps' (bitterns) in a day, an' shot three on 'em, an' thowt nothin' on it. Now, if one is heerd on, every man Jack as shoulders a shootin'-iron is on the rampage arter it. Why? 'Cos they're scarce, and gents ha' got a craze for 'em for stuffin' 'em, like as they hev them pretty black an' white avocets. I've heerd my father say as how them long-legged critters built their neesen by them trees out hinder, an' a lot of old herons built in the treetops, which seems a funny thing for a waterbard tu du. Why are the bitterns an' them no longer plentiful? Why, ain't they drained the meshes (marshes) an' the lowlands, turnin' thousands of acres into pastures and cultiwation? l've heerd my owd dad say-an' true it wor tu-

\section{'For we shall rue it, if't be true \\ That Fens be undertaken; \\ An' where we feed in Fen an' reed, \\ They'll feed both beef an' bacon.'}

An' don't they? Besides, there ain't the lay (shelter) for the bards theer was; would yow cum here, Mr. Painter, if yow cuddent git a place worth the daubin' on that 'ere pictur'? Wal, that's the way with them. As tu them clinkers (avocets), I've heerd the old man say, them chaps as fish for salmon up in Newcastle was the cause o' they a-leavin'! indeed, they wor wiped out clean for the sake o' their feathers, as was made up into artificial flies. We see one now an' again, so we du a bittern, but they are furreners, as only cum over in April and May. If they don't stop they git kilt, and then they're obliged tu, sure-ly.

'Lor, gentlemen, times is altered altogither. See them geese hinder? Yeers ago we used tu rear thousands, afore iron an' brass pens was made. We bred 'em for their quills an' feathers, and gozzards (goose-herds) were as much thought on an' wanted as shepherds is tu-day. We plucked 'em alive four or five times a year, fust at Lady-day, for body an' wing feathers, t'other times for body feathers only. The young 'ens we broke in even at six weeks old by pluckin' out theer tails. Cruel? Wal, 'bor, I s'pose yow'd reckon it wor, and p'raps it was. But yer see things wor different then. Yow can't whack a stubborn owd dicky now, so I've heerd say, athowt a man in brass buttons hevin' yer afore the beaks. Pritty how tu du ! An' then there's everything else as is gone wrong. We used tu burn dried cow dung an' hovers (peat); now we hev' coals, in course-them puffin-Billies (trains) ha' turned all that over, not as that matters much. Theer's a change tu they ha' made. We used to be quiet here once, 'bor, but now see what swarms of folks a holidaymakin' they turn in upon us. Yachtin' I kin du with, providin' them chaps in 
blazers on 'em doan't overdu it. But I hate them steamers as upsets every mortal thing, tearin' through the water like nobody knows what, frightenin' bards, an' scarin' fish, an' playin' the wery trundle up with everything. Theer ain't the fish in the rivers theer wor, for how kin the spawn, dashed an' knocked about by the swell among the reeds, ever cum tu life? Then them landowners as hev' been pullin' the string, closin' up the Broads for shootin' an' fishin', and tellin' yer yow

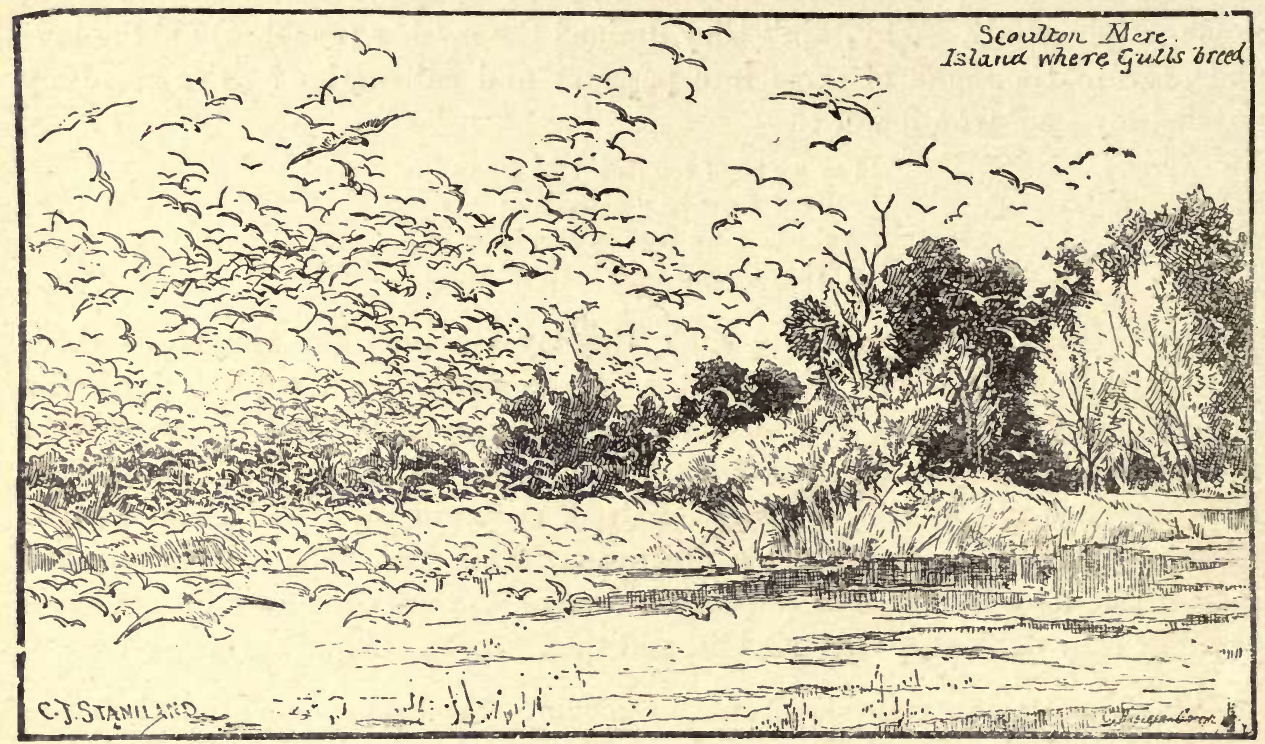

mustn't go heer nor theer. Why, it's sheer robbin', of us, it is, of our rights. I've heerd say,

'The law locks up the man or woman

As steals a goose from off a common,

But lets the bigger robber loose

As nicks the common from the goose.'

'An' I doan't know as that ain't the way things are goin' on everywhere else. Ah, gentlemen, things are goin' wrong-altogither wrong!'

Much more does the ancient fellow unreel of his yarn of things that have long since vanished, regretting the passing away of old times as a calamity to be bewailed. But we humour him, for an old man has his weaknesses; he loves to 
talk, and grumble, and ruminate. And why shouldn't he? He too, like the old order of things, will soon have stepped into the obscurity of the past, with his quaint attire and quainter ways, and his store of ancient history.

We are once again afloat, leaving the artist to listen to the rest of the old man's rhapsody. Coots, moorhens, swans, grebes, and various hedge-birds are seen and watched in turn. In a corner of the Broad we come across a brace of young urchins, busily catching small roach and tiny gudgeon. And right merrily the truants, for no doubt the schoolmaster will know them well as such, are hauling out the hungry finners with an osier twig and a bit of string, upon which a bung is made to serve the purpose of a float. With their towy heads, plump naked legs, and ruddy cheeks, the youngsters look the very picture of health and carelessness. They will trot home betimes to receive a drubbing, no doubt, and a 'hunk o' bread' for supper, and make, perhaps, as little fuss over the one as they will ravenously enjoy the other. May care sit as lightly on their shoulders in the days to come as it does to-day! Hosts of black-headed gulls are making merry on the Broad. Some are washing their spotless plumage in its cool waters, others are apparently at rest, whilst many are taking exercise on airy pinions, for they have no doubt been spending long, tiring, hopeful hours upon their large brown-speckled eggs. Not far away from here, on a swampy island, hundreds of nests may be found containing eggs in every stage of incubation, and many of them already are tenanted by the yellow downy puff-balls of chicks. These birds at breeding time are strictly preserved; many hundreds of the earlier eggs are taken by the keeper, and realise a goodly sum; they are not bad eating. The eggs are laid in a cavity formed by trampling down the broken tops of the reeds and sedges, and generally number three. It is a sorry time for grubs and worms for miles around when the gulls come home to their breeding-grounds; they scour the countryside for many a mile; and Farmer Giles looks upon them with a kindly eye.

Thick clouds have been piling up in the west, and big raindrops dancing on the surface of the water warn us to seek shelter from the coming storm. We pull away hard for the staith, and reach it not a little moist, for the shower is pelting down in a seeming hurry.

Right gladly we rub shoulders with our naturalist friend of the morning as 
we enter the village station, and it is a right good time he treats us to over the 'luck' he has had in his day's perambulation. Need we say we offer no negative to a pressing invite to turn over with him at nightfall the treasures he has been collecting.

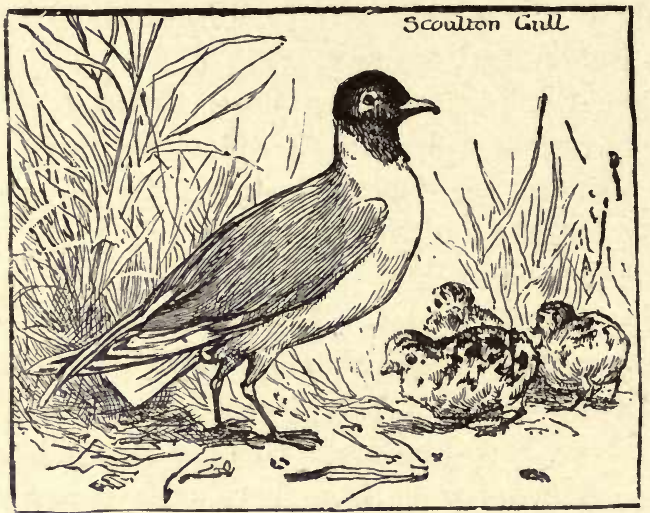

BLACKHEADED GULL (Larus ridibundus). 


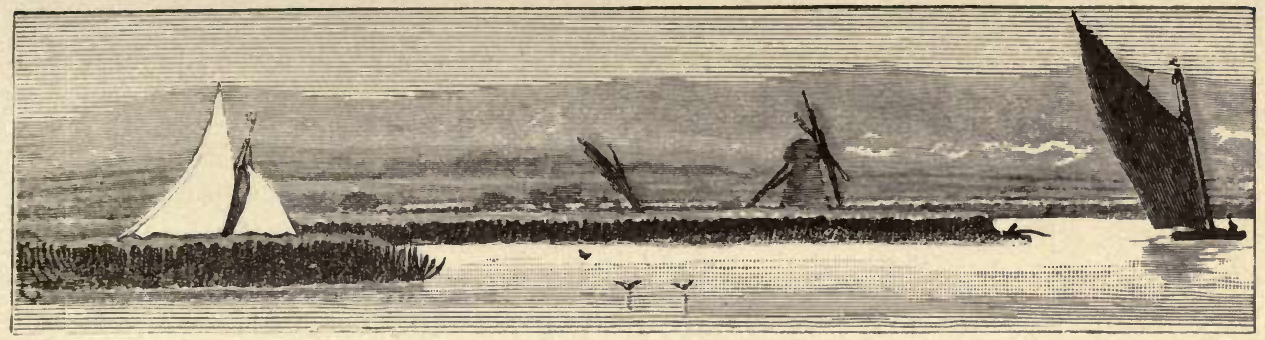

\section{JULY IN BROADLAND.}

'Glide gently, thus for ever glide, 0 Bure! that anglers all may see As lovely visions by thy side

As now, fair river, come to me.'

MID a blaze of colouring, and beaming with sunshine, July makes its advent in the 'Land of the Broads.' A thousand forms of insect-life hum and drone its praises as they dance and flirt in the sunlight; a legion of wild-flowers open their petals and welcome its warm kisses. In town and city the heat has become oppressive, and hosts of holiday makers crowd down to the sea-shore and the country in quest of rest and health. We, too, would banish awhile the worries and cares of town-life and take a longed-for respite from them. Broadland, with its quiet waterways and quieter lagoons, is to us far preferable to the more animated resorts where, even in their hard-earned leisure, each yet jostles against the shoulders of his fellow. Give us the silent-flowing river and the silvery lake, where the ripple laps soothing music around the white-winged vessel, and the tall reeds rustle and sough as the playful winds sway them to and fro.

Our friend the artist is still at work on the Broads with brush and palette; indeed, so busy is he that he has banished himself awhile from society, and in his quaint Noah's ark of a house-hoat is living afloat, taking his house as the snail takes his, wherever he may feel disposed for the time to settle. Gladly have we agreed to spend a day or two with him.

Our old acquaintance, the wherryman, most fortunately, is about to loose the Iopsy from her picturesque moorings near the old North Tower, taking advantage of the early flood. He has recently brought down a cargo of oak-billet-timbers 
in three or four feet lengths of the more slender boughs which are useless for sawing into boards. These lie piled upon the quay in a distorted stack; a couple of guernsey-coated fellows are busily loading a barrow-cart from it, their destination being a fish-curing house. That billet, in the autumn, will give out volumes of dense smoke beneath thousands of North Sea herrings, turning with its pungent qualities silvery fishes into delightful tit-bits for the breakfast table, and into bags of gold for those who cure them. In its place the Topsy has now a generally assorted cargo.

Merrily clinks the winch as the enormous brown sail slowly expands itself, and the gaff is run well up the great mast. 'Let her go!' shouts the skipper to his mate, who lets her go, loosing her by a dexterous jerk of the rope, which lifts its eye clear off the mooring-stump ; this is pulled aboard and stowed away. As soon as we clear the surrounding buildings we catch the breeze, and away like a thing of life the Topsy glides, cutting the water as a ploughshare slides through the crumbling earth. It is blowing a fair wind to-day, and right quickly we pass the objects on the river-banks. Sleek kine stare wonderingly at us from beside gnarlytimbered stiles, here and there a marshman's cottage and its surrounding alders looms into view, and then a drainage mill.

' Tree-and-twenty miles, 'bor, oan't take us long tu du tu-day if the wind holds good,' says the skipper. 'So 'tis Stalham yew're bound for; wal, that wor lucky, as I happen tu be goin' theer tew. What a rummen yer painter friend is. I never seed a feller rub on the colours same as he du, so quick tew; why, afore he ha' run his brush over half a dozen times yew seem tu know the wery place as is comin'. Here's a pictur as he done the t'other day an' gie me, there's his house-boat wi' the chimley. Front on it is old Tyke Barber's yawl, with his eel-set aboard it. Agin her bows is a gun-punt. In course that's me a-sitting in the boat. How natural them reeds a-frontin' us look, doan't they? Some are growing straight, others a leanin', and them broken ones look as real as they wor. 'Bor, how I larfed one day as he wor a sketchin' on a rond (Dutch rand). He'd jest finished his pictur', an' gone aboard for suffin' leavin' it on the sticks. An owd cow as wor munchin' close agin it walked up an' took a boss at it. She seed the grass an' sich like, and a likeness of a small brown calf. What did she du, 'bor, but begin lickin' it, thinkin', no doubt, as how that wor one. Yer friend cum out savage enuf an' shied a bucket at her. Yow would a larfed-I did-tu see that old hussy hain up her tail an' dance across the rond like as if she enjoyed the fun tu.'

The wind meanwhile has been increasing. Our craft has all the sail she can carry; our leeward plankway is under water. A sudden squall, a regular 'Roger,' 
for which our men are prepared, strikes us; and heavy rain drops down from an overcast sky. Some yachtsmen ahead are not so fortunate, they have run aground. They hail us as we pass them, but we are going too rapidly to be able to give them a helping hand. Now a bridge rises up ahead of us, with a single low arch.

'Stand by the winch, Jem. Now lower, my hearty, and let her go.' Down rattles the great tanned wing, the parrel is taken off, and the jaws of the gaff moved aside. Jem now casts off the fall of the forestay tackle from the cleat on the block. Balanced so well that a child could sway it in its tabernacle, the great

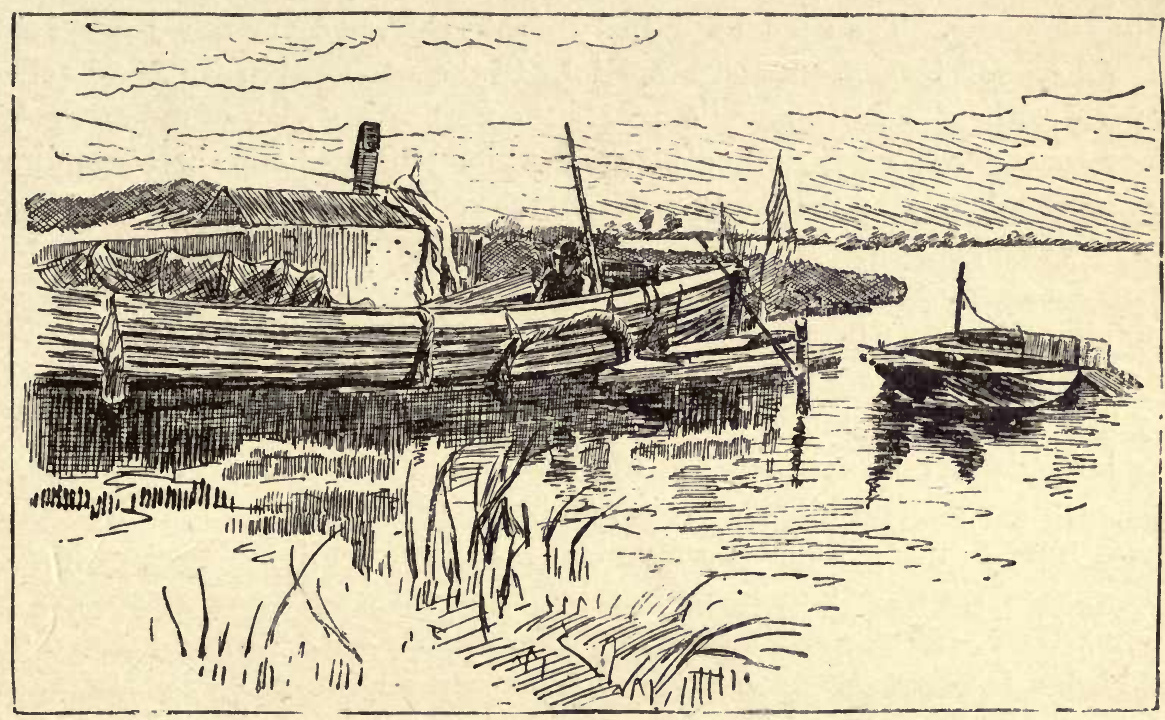

A WATERSIDE RENDEZVous.

mast sinks slowly down as the ton-and-a-quarter of lead on its heel rises into view. 'The skipper's hand is on the tiller, and with his keen blue eye he judges to an inch his bearings. Straight through the arch like an arrow the good vessel shoots, with barely a foot to spare above head. So nicely, too, has the time been judged that our mast has but reached its level when our bows have entered the archway. No sooner is our helm clear than the mast is raised and the sail is up, and we are on again as fast as ever; indeed, we've scarcely lost way at all.

Pass we eel-babbers on their way to some favourite babbing-ground for the night's fishing; on past mills and houses, between long thin beds of reeds and 
sedges, each turn in the river bringing to view fresh aspects; and presently we find ourselves nearing our destination. A passenger-boat, crowded with excursionists, goes by us, its screw throbbing and churning up the dark waters, leaving in its wake a great curling swell that licks the crumbling bank on either side and follows the boat in its progress. These excursion-boats are doing immense damage to our river banks.

We are not left standing long at the village staith ere our artist-friend rows up in his little dinghy; stepping gingerly in, we are very soon on our way to his floating domicile. The wind has lulled considerably, and the rain has ceased to fall. All around looks fresh and beautiful, and the setting sun, as if loath to leave the world without a parting smile, paints the west with a glow of red and golden. A swan comes fussily up, ruffling his snow-white plumage, and threatens us with every mischief, only he fails to keep his promise. His mate, with a brood of dark downy cygnets, is beside yon reedy bank. A couple of flappers (young ducks) start out from a clump of rushes and take a short flight across the Broad. Sedge-birds are piping their last short songs of the day. A heron, trailing its long thin legs behind it, has taken to wing at our approach, his great awkward wings bearing him away to some quieter location. On our right stretches a patch of water-lilies, their large flat leaves covering thickly the surface of the water; there are the great open flowers, white as the snows of winter, lifting their beautiful heads above them. Here in the glorious morning sunshine in mazy flight dance and coquet many an insect, whilst blue metallic carnivorous dragon-flies take erratic flights amongst them, and the swallows dash hither and thither. Great cautious roach prowl below in search of larvæ, the former scrupling not to make a snatch at some insect momentarily resting upon the water. Coots and moorhens, which clicked and croaked all day long in the shelter of the reeds and sedges, are mustering their chicks around them and venturing out into the open water. Starlings are settling in the reeds for their night's napping. What a murmur as of the sea their wings make among the reed-stems as our oar accidentally sweeps through the outside edge! The first broods of the sand-martins will soon drop in and share their strange roosting-places with them. Reed-warblers are singing all over the Broad, and a sedge-warbler here and there joins in with a louder melody. Orerhead the noctule-bat shows his frittering wings dimly against the waning light; the cockchafers, for which he seeks in droning flight, are out on their nocturnal rambles. The barn-owl and the field-mouse, on which he preys, are afield together. The crake of the land-rail becomes familiar. The stars twinkle out one by one, and the moon 
peers from behind the riven clouds whose edges she has been tinging with silver. A slight breeze rustles soothingly through the reeds and sedges, fanning our cheeks with its cool breath as it passes by us.

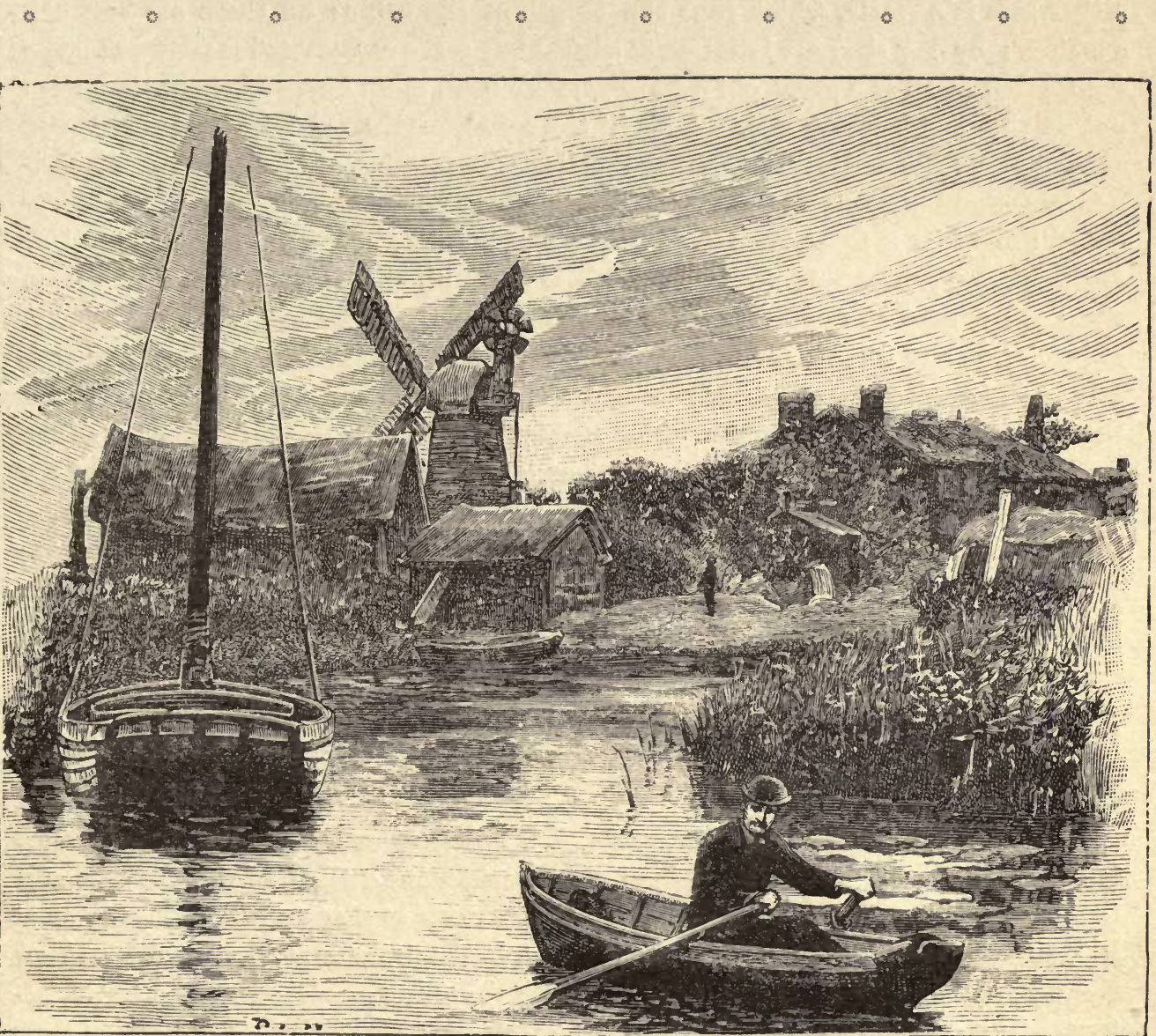

S'TALHAM DYKE.

We have been.watching many of these changes from the stern-sheets of our artist-friend's house-boat. The dinghy is moored astern of us. Meanwhile he has been lighting a fire and preparing a jolly little supper to complete the evening's enjoyment. The smell of provender and the refreshing aroma of tea filters out into the quiet air and rouses us from our reverie, for whilst he has been busy we have 
been left to enjoy our silent vigil. What a proper spread to be sure, and what a nobby home-like cabin in which to spoil it! Let us describe our ark's interior. As you enter you are obliged to stoop, for the ceiling does not admit of standing. On either side is a settle, which runs the length of the cabin: on them are soft hay cushions; by day they are lounges, at night they serve as beds and mattresses. The foundation of all is a great old fishing-smack's boat, more knocked about than worn out on the rough North Sea. A bit of timber strengthened here and there, and she answered famously. Beneath the settles are a number of lockers, in which various household utensils find storage. A stove faces you as you enter from the sternsheets; upon its magic bosom our friend works wonders in the line of cooking. The cabin is double-boarded; and snug cupboards fill up the corners of it, and within them are stowed the crocks and some other essentials for use and comfort. A swing lamp, and ditto table, a tiny clock, and an aneroid barometer form the articles in suspension, to which may be added a fishing-rod and a fowling-piece for use when legitimate occasion offers. The grainer and painter have added much to the general appearance. Supper over - and such a supper and appetite to boot, for the Broadland air is provocative of the latter-we turn in; and wrapping our Austrian blankets around us, sleep as only tired folk, at peace with God and all men, can do; but it is late ere oblivion enshrouds us, for pleasant gossip goes on until speech becomes incoherent and nature gives in altogether. We are not without floating neighbours. Astern of us lie moored a couple of small yachts, covered by canvas awnings. Beneath them are sleeping two parties of lusty young students, who are 'doing' the Broads in quest of health and pleasure after months of wearying toil and study. Such is a summer's night spent in Broadland.

We wake an hour or so after midnight, and steal out to take a peep at what is going on around us. Skylarks are already welcoming the dawn of the peaceful Sabbath, one is actually aloft, but it is yet too dark to discern him. The moon is hidden again, but the stars are yet glistening in the firmament, their reflex making the waters look cold and silvery. Gradually the dawn steals over the face of nature. The small birds are waking and the bats are still flitting as if loath to turn the night into day. The crowing of cocks sounds afar and near: and the snoring of our artist-friend inside sounds nearer and louder. Black-headed buntings are tuning their morning songs, and the twitter of the swallows announces their search for an early breakfast. By three o'clock the stars have become dim, and the blue sky abovehead is streaked with purple and crimson. In bunches the starlings are quitting the reed-bed, and the quiet waters in which the big brown 'pokers' of the bulrushes are reflected become agitated with concentric rings as the large fish 
rise at the flies upon the surface. The cry of the redshank and the harsher note of the heron are heard as they change their feeding quarters. The trained ear of the naturalist distinguishes other bird cries.

The monotonous ding! dong! of the bells in the village belfry is summoning man to worship his Creator. The quiet of the country on the morning of the Sabbath is delightful. Clad in their best apparel, rustics old and young are wending their way towards the sanctuary. Round the porch of the old grey church stand and gossip many of the simple villagers; politics and agriculture and the troubles and doings of each and his neighbours, come in for a share of harmless discussion, until the parson makes his appearance, when hard, horny hands make clumsy salutations, and they follow the good man inside. Bewitching strains of organ and boyish voices, mellowed by the obstructive walls and windows, fall on our ears, and awaken hallowed feelings as we leave the man of God to 'lure to brighter worlds and lead the way.' Hearken to those familiar words-

'Hark! hark! my soul: angelic songs are swelling'

O'er earth's green fields and ocean's wave-beat shore:

How sweet the truth those blessed strains are telling

Of that new life where sin shall be no more.

Angels of Jesus, angels of light-

Singing to welcome the pilgrims of the night.'

Oh! how these beautiful words, as the verses go on, touch our hearts. A tear steals down our artist-friend's cheek. Surely the words and these sweet voices are recalling sunny, and mayhap sad memoriès. That old hymn has touched a very tender spot in his noble soul. We link our arm in his and stand silently beside him. We care not to break in upon holy thoughts and emotions by conversation. Presently we find ourselves inside the house of God.

Our artist-friend has some letters to write in the afternoon, hence we pull to the village staith alone, bent upon attending service at the 'Ranters' chapel, as such places are yet occasionally called in our remoter hamlets.

' 'Tis over yinder, by that big owd elm-tree. Foller yer face down yon 'loke,' then turn at the bottom, and yow'll find it close aginst the willage smithy.' So directs us a tousle-headed urchin, with a hedge-sparrow's nest in his Sunday cap and a cane-suggestive rent down the leg of his breeks. Sounds of lusty singing 
from a cottage-like building, with martin's nests stuck in its windows, are sufficient to denote the purpose for which it was erected-

'Hark! the Gospel news is sounding,

Grace for all is rich and free,'

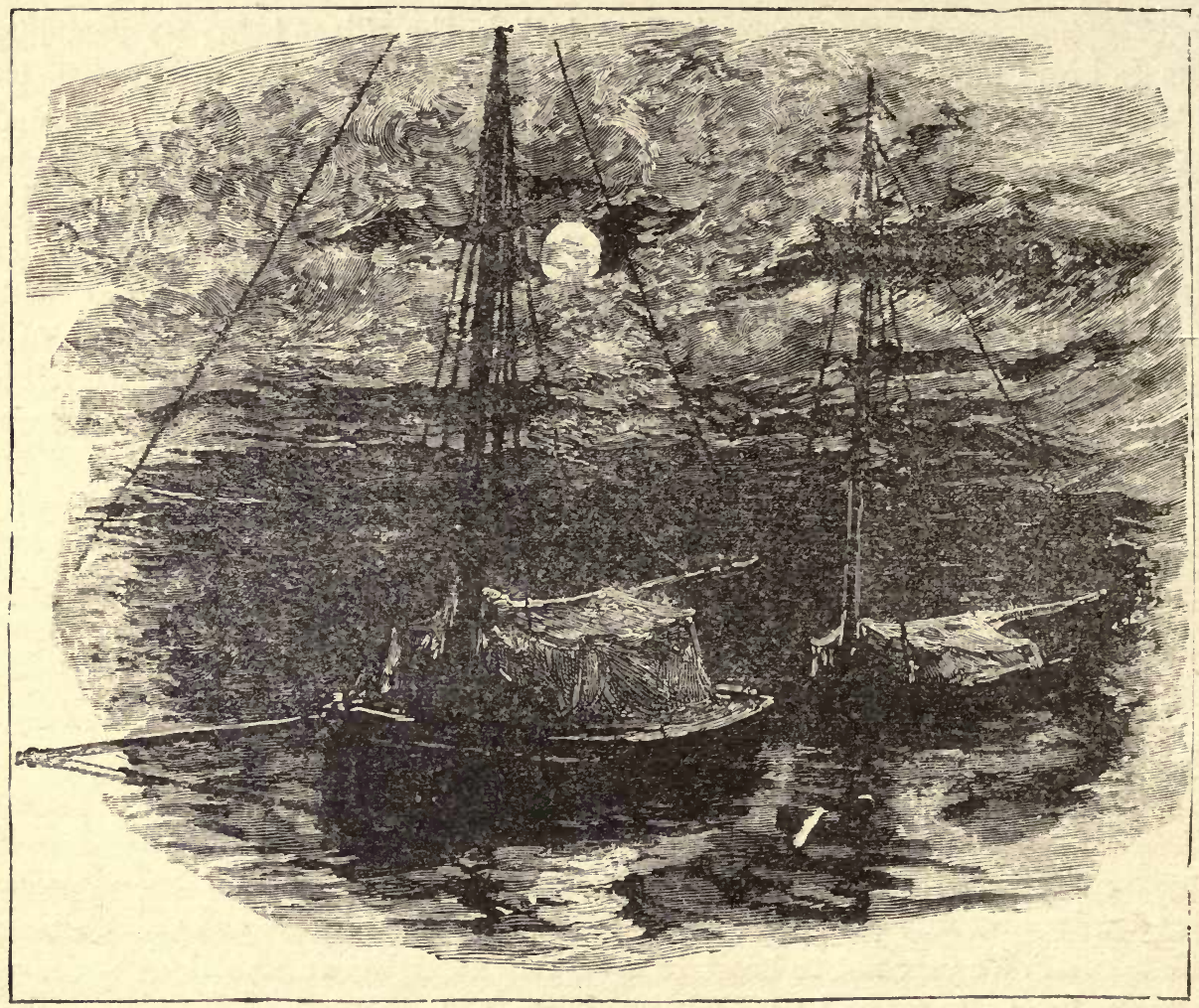

BEDTIME.

reassuring us that the Primitives unmistakeably worship there. We are ushered into a pew as plain as was ever put together by nails and hammer. Most of the seats are occupied. Sons of toil and their wives and kindred earnestly worship their maker in song - song that stirs the heart rather than softens it, that makes the soul feel strong and aggressive, and that refreshes it. A shuffling of feet upon the sandy floor follows the finishing of the hymn. Red handkerchiefs dot the hard cold ' pam- 
ments,'and sturdy knees bow humbly before Him who readeth the hearts of all men. An aged brother, bent with the weight of years, who occupies the tub of a pulpit, pours out his prayer before Him. His stentorian voice is drowned at times by the louder responses of those below. Everyone, save some fidgety youngsters in a corner, appears profoundly devout; one of these is brought to his senses by a box on the ears, administered by one whose duty seems to be to preserve order. The urchin evidently has been expecting this, for he takes it as a matter of course, and winks an adjournment at his companions until Farmer Giles has settled for his usual nap.

Our friend in the pulpit apologises for the non-appearance of the local appointed for conducting the day's services, and takes them over himself rather than let the time pass unimproved. His explanatory reading of the parable of the sower, a favourite one of his, and one which he has given them more than once before, meets with general approval, one and another good brother putting in an idea which considerably enlivens the proceedings. His remarks are practical as well as pungent. More hearty singing follows. Then comes the text. ' Friends', he says, shutting the open Bible with a bang, ' yow'll find it in the Dan'l v., part of the 22nd wearse, 'My God hath sent His angel, and hath shet the lions' mouths,' adding, 'and ha' kivered up theer teeth,' as a supplementary text of his own. Here the trial of ' Dan'l' is graphically detailed, interspersed with many original ideas and no end of quaint Norfolk jargon. Evidently our friend reads his newspaper, for your rustic has learned to think for himself; even the aged, who are behind the village times, plod on in the wake of the more eager steps of the rising generation. He, like many another rural dissenter, whilst showing proper deference and respect to the squire and parson; has long enjoyed the benefit of his theological convictions; and whilst there is nothing of the Socialist in his creed, he loves and advocates freedom of thought, and believes in the equality of all men, at least before Him who created them. But to the 'sermon.' Here is the gist of it:-

'Dan'l wor put in the wery topmost bough of the social tree, becos he was reckoned the wery best man tu hold hisself on it. He wor teetotal, as ivery Christian shud be. A man as wor sich kept a clear hid, an' cud run a straiter furrow than him as got fuddled at the King's Arms, or the Risin' Sun. An' the king didn't go about with his eyes shet. Then jealousy, like a bed of nettles, crops up, and makes it warm for poor old Dan'l. What oan't folks du when jealousy's got fairly ruted? Then that paaper what they got the king tu put his name tu. What fules folks make o' theerselves when they sign anything athowt proper thought and consideration! Them lions wor kept tu claw up folks, as we keep 
rope tu hang them as ha' done crimes tu awful for 'em tu remain on the airth. The martyrs know'd summat about lions. Did Dan'l giv up prayin'? Not he. He didn't put off his prayers till he got atween the blankets an' then slept on 'em, he wasn't afeard to jine in the prayer meetin' for fear folks shud hear him. He opened his winder. Some on us would ha' banged it tu an' drawed the blind. Dan'l didn't. Then they tiptoed under the window, and heerd him. 'Alright,' says they, 'Dan'l we've got ye.' Darius done his best for him, an' didn't think no more o' the tattlers for theer spite an' tell-talin'! They'd heerd Dan'l and theer warn't any breakin' o' the law o' the Medes an' Prussians. Why didn't Dan'l be keerful ? Couldn't God heer a whisper? Of cos He ken, but that warn't it, it wor stickin' tu principle. Darius whispered in his ear words of good cheer. I reckon them fellows got the keepers tu forget them lions' suppers a day or tew aforehand. In they popped him. How them big men stared when them ravenous beasts fell to lickin' instead of eating Dan'l! God sent His angel. If Dan'l prayed upstairs, I reckon he didn't give up now. Darius had a rough night on it. A guilty conscience wor wuss 'an sleepin' on a heap o' sheep-hurdles or under a harrer. He was a airly riser next mornin', and cumin' tu the gratin whined out, 'Dan'l are yew theer, or are yew eaten up ?' Dan'l said, 'Alright, guvner, I'm all serene, God ha' sent His angel !' And friends, ain't God shet the lions' mouths for yew full many a time?' (A chorus of answers in the affirmative follows the question.) 'If the lions oan't eat Dan'l,' says the king, 'yew must out with him.' So Dan'l wor hauled out alright an' riddy for his breakfast. But the wust wor yit tu cum, his inimies wor hulled in an' made breakfast for them starvin' lions. And friends, ain't it true that the sins of the fathers is wisited on the little uns? Ah ! friends, I allers pities the innercent little uns. And note yew, them as dig traps for others gin'rally fall in theerselves. I once knowed a keeper put a shot intu a fox as wor about tu spring on a hare; had he not been arter the hare he'd not ha' bin shot most likely.

Our 'parson's' lessons drawn from the narrative are, 'First-It ain't allers aisy work tu sarve God; second, If we want tu be good an' prosperous in this world an' the next, we must be prayin' people; third, It is allers best tu take our troubles an' our cares tu God, for He'll señd His angel tu shet the lions' mouths.'

0 6

Another night on the Broads, an early row round, and a dip in the cool fresh waters, and away are we hurried in the rumbling train to the worries and bustles and responsibilities of the work-a-day world. 


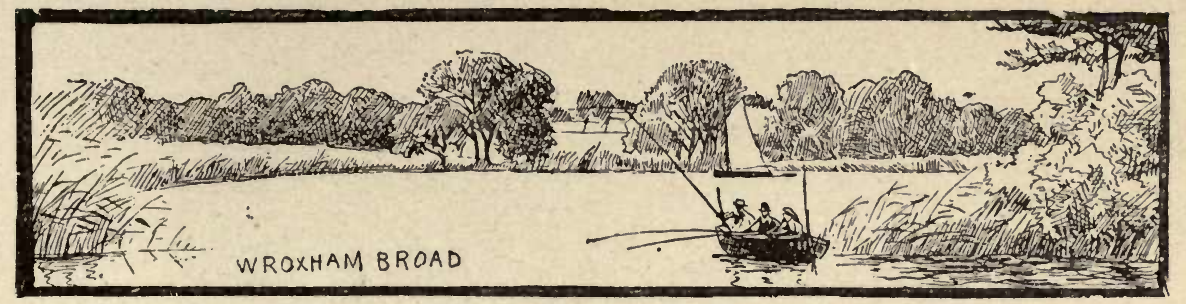

\section{AUGUST IN BROADLAND.}

'Oh! the gallant fisher's life,

It is the best of any;

'Tis full of pleasure, void of strife,

And 'tis beloved of many.

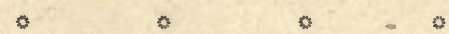

For our skill breeds no ill,

But content and pleasure.'

-Izaak Walton.

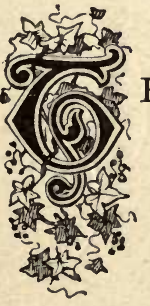

HE fair warm days of August dawn upon ripening fields that are 'white unto the harrest.' The sound of the whetting of scythes becomes as familiar in the countryside as the chirping of sparrows in the hedgerows, and the hum of bees among the gaudy wildflowers. There is little time for leisure just now at the farm, for Hodge and Farmer Giles, his ' maaster,' are taking advantage of the 'wather.' Every fine day has become precious, the depredations of the swarming birds and the fear of sudden storms make it imperative that the fields should be shorn of their wealth and beauty with all possible haste.

It has been market-day to-day, and one by one, as their stalls have been stripped of the produce of the coop and garden-patch and the output of the dairy, the country-folk have harnessed their horses and turned their heads homewards. It is a pleasing sight on a market-morning to see the heavily-laden carts, with springs strained to their very utmost, piled up with the good things of this life, coming rumbling into town. Those who hold the reins, and those who sit beside the driver, are more quaintly dressed than picturesque, and the broad Norfolk 'patter' they dispense in the market-place is quainter still. 


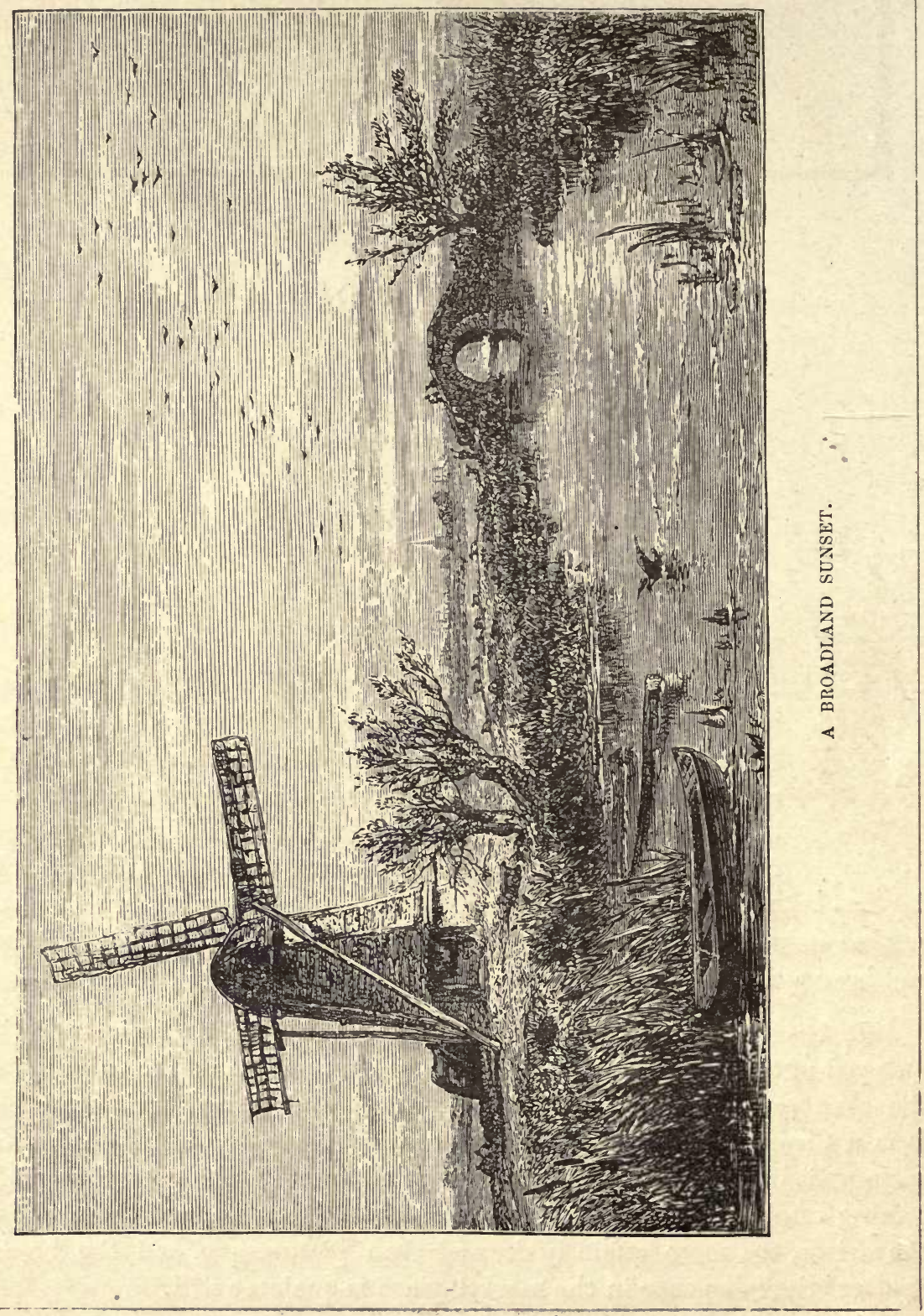


Behold us in the afternoon of a hot August day jog-trotting along upon a tough old vehicle that has rattled backwards and forwards these many years; the painter has not seen it since it first left his hands. A towy-headed rustic, with a broad-brimmed felt hat, turned down in the orthodox fashion, has the reins, and old 'Nelson,' whose pace, in spite of threats and persuasions, has not altered one whit since we started, is shambling doggedly along. The good man's 'missus' is sitting on our right. Between two such substantial mortals we feel quite small. We may not describe her habiliments - they are more than half a century behind the city fashions.

Our driver takes great pains to point out with his lashless whip-stalk every thing that he imagines of interest to us, from the churches and parsonages which peer out from between crowding trees, to the barley in the harvest-field that is ready for the carting. His talk is of all that is rural, and of not a little that isn't.

' 'Bor,' he says, 'farmin' ain't what it wor when I was a youngster. Theer's a heap of things as have altered since 'the good old days long ago,' when gleaners picked up the stray ears, and harvest hoam wor one o' the sights an' most pleasant doin's o' the country. Law! the powetry's all knocked out of it, what wi' the bringin' in of machinery, and the buyin' up of corn from them furriners, the hull (whole) thing's got transmorgorified. Time was when the sickle an' the scythe cud du what wor required; but folks ha' got a sight too go-a-head nowadays, and now yow must hev a heap o' machines a cuttin' out labour, and doin' the thing so grandly. But sorry times ha' dawned on us, for all that 'ere, and ain't likely tu bettern while them 'Mericans an' Rooshens send theer ships with many a ton, and du it cheaper, tu.

'The willages ha' got behindhand tu, for many a lab'rer leaves 'em for the towns; but theer, 'bor, yow know as much about that, and the evil days we've lived tu see, as I ken tell yer of 'em.'

'Good arternune! Mrs. Gammut', is the salute he treats an old lady to, who is alternately whacking and jerking the reins of a scraggy and ancient donkey, that is slowly trundling the aged soul along. Mrs. Gammut has been to the town for her 'washings,' as the baskets of linen piled up in her little cart bear witness. It was early morning when the obstinate 'dicky' left his stable, in which he hopes to munch his supper by nightfall. The surviving folk of an almost obsolete generation take things easier than the present, and live the longer for their unambitious jog-trot, doubtless. Mrs. Gammut bids us 'Arternune,' and amidst her heaps of linen essays a little curtsey. 
Ere we get our supper at the Marshman's quiet cottage, we ramble out into the dusty lane. We could not loiter to admire the campions dotting the hedgebanks with their whites and pinks, or the pale pink bells of the bindweed. There is a perceptible decrease in the number of wildflowers; those which are yet unfolding their petals are bright and gaudy. Here we find the stately corn-blue-bottle, the scarlet pimpernel, yellow hawkweeds, spreading mallows, scarlet poppies, and many another. Insects of many species dance to and fro above the flowers, and the low-flying swallows and martins are busy snapping a supper from amongst their heedless swarms.

There is a promise of rain. Dark patches of cloud, scarcely larger than a man's hand, are hastening up from the west'ard, those behind growing larger and lumpier as they journey towards the east. The dust is lifted from the roadway with the puffs of wind that fitfully travel before the advancing shower, and whirl it upon the hedges, enveloping the passer-by in its dirty shroud. The fir-trees sway to and fro as it increases, and the willows flutter their pennon-leaves as if eager to catch the hastening raindrops. High over-head some great grey gulls are 'shayling' in erratic flight, making seaward.

At the Broadside the reeds and sedges are swaying and bending before the breeze, rustling their stiff leaves and tall stems against each other, till a murmur like the waves beating upon the seashore falls on the ear. The few remaining leafless stems of an older growth crackle and fall one by one, to float awhile as at anchor, and then to sink beneath the surface and find burial in the waters, as their predecessors did before them. The sedge-birds have ceased their merry warbling and chirp discontentedly; feeding and perching have become hampered and irksome in the troubled reed-clump. The rain patters down in a smart drenching shower. Out on the Broad the coots and moorhens are revelling in the showerbath; the grebe and its striped progeny paddle out boldly into the open.

It is unpleasant tramping and crouching beside the hedgerows; they afford but a sorry shelter, and the finer particles from the baffled raindrops filter through the thorn-sprays. The brier smells all the sweeter for the refreshing moisture, and vegetation in general looks the brighter for the big drops that wash the dust and dinginess from the myriad leaves. The wild-flowers are gayer too, they will be smiling and looking at their best with the return of the sunshine. How the wind shakes the stiff old oak branches, and flutters the dark green ivy leaves that spring out as if from its gnarled trunk! 


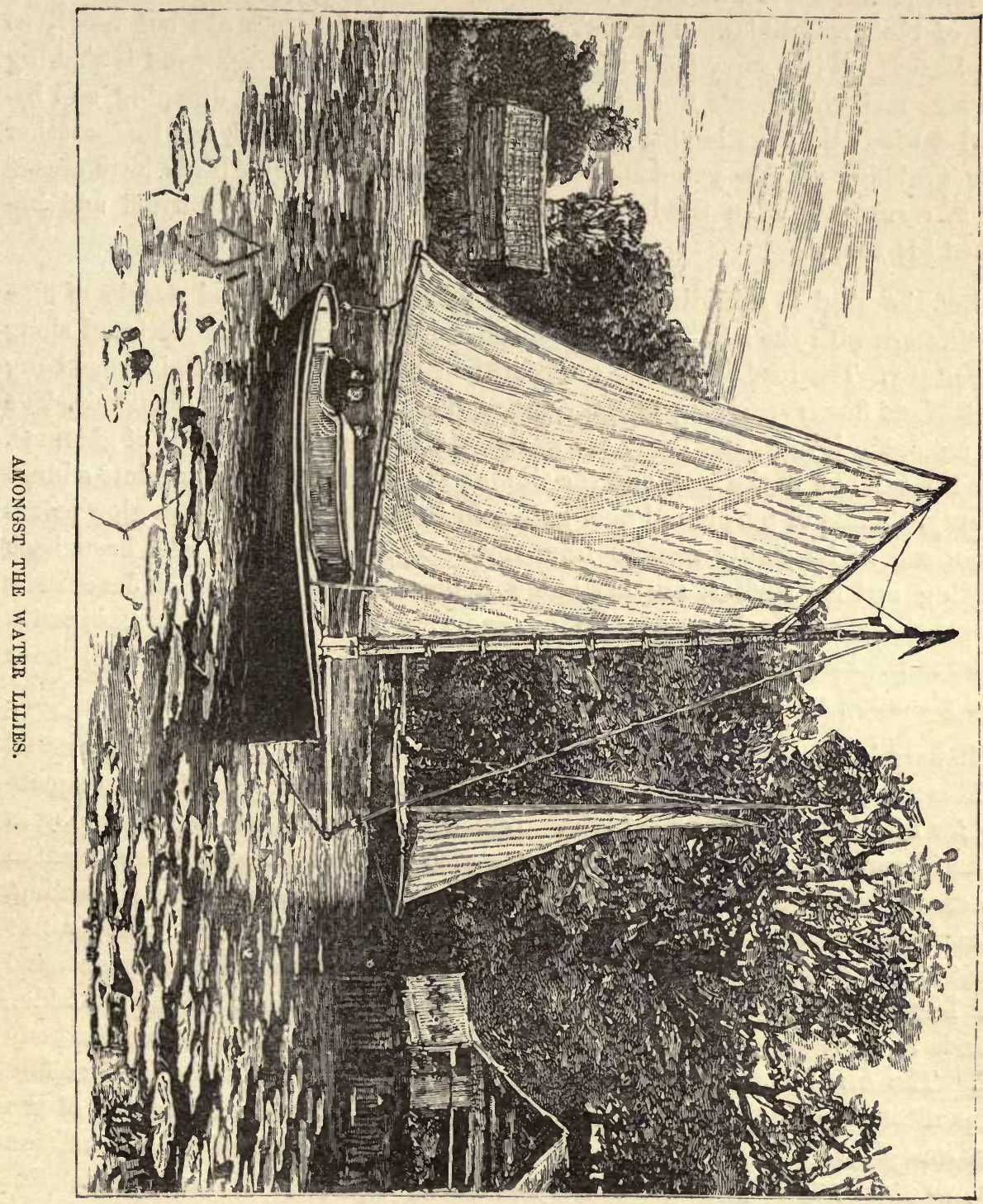


Note yon slender pied wagtails nimbly running by that roadside puddle! The rain troubles them little so long as it washes the gnats and midges within reach of their mandibles. The rooks upon the old elm trees are not nearly so well pleased. It is a sorry time they are having while the rough wind is shaking the twigs and grass-bents from their family mansions. With drooping and bedraggled wings they are hoping the squall will soon have passed, and that another hour's grubbing may be yet done before nightfall. The song birds have ceased their merrymaking, even the lark has dropped in the stubble dispirited and has finished his song.

But the wind is subsiding, the thick clouds have parted, and streaks of blue peer through with the sunlight. The storm is over, dead twigs lie scattered along the roadway. The roadside hollows are filled with turbid water. Raindrops hang from leaf and flower sparkling with the lustre of so many pearls and diamonds. The birds are again joyous, and many are warbling their delight in a song of gladness. There is a rainbow in the east, and the sinking sun is kissing all Nature into a blush of beauty. Tints of purple and gold gather in the west, and a crimson glow paints the horizon as he slowly recedes from view. The harvestmen, who have been 'standing up' for shelter, are hastening homeward, our old friend Jem Trett amongst them. It is almost needless to say we enter into a friendly confab, which finishes at the Broad-margin, where we take leave of him to enjoy a quiet half-hour in the gloaming and quietude of evening.

It were intensely quiet but for the varied sounds which Nature makes around us. There is quite a riot, indeed, in the reed-bed; the crowding starlings are squabbling for roosting-places for the night. Bunch after bunch have been dropping in this half-hour. They have filled their crops with grubs and beetles, have executed their characteristic gyrations in the air, and would settle to nap till early morning. But each fresh company on arrival disturbs its luckier companions, who protest against the invasion of their rights. The moorhen's harsh croak is frequent, and other less familiar notes are heard at intervals. The ter-ick of the partridge resounds in the fields, and the soft cooing of the turtle dove issues from the leafy wood. The hirundines are still dashing to and fro. A small wading bird flies past us uttering a peculiarly shrill, piping cry, which we recognise as that of the green sandpiper. A freshly 'fyed-out' dyke we passed has had some attraction for it, no doubt; this species loves to hunt among the débris of the ditches.

Harken to that queer jarring sound! it is like the shaking of a rattle or the turning of a ropemaker's wheel. It is none other than a fern-owl or night-jar 
doing his best at an even-song. Moths had need 'ware' fern-owl, for his capacious mouth makes sepulchre for the largest of their race.

'The busy dor-hawk chases the white moth

With burring noto-'

The bats and owls are rousing themselves in the village steeple, they will be out ere many a diurnal creature has tucked its head under wing, or curled up its furry body for its nightly sleep.

Big fish are rolling near the surface as if in play, and many a luckless fly is snapped up as it floats across their vision. The distant boom of a fowling-piece is now and again heard; the wild-fowler is lying in wait for 'flappers' (young ducks), whose young lives trickle out with their blood; their first short flights across their native Broad are often fatal to the species.

Supper in the marshman's cottage we may not dare dwell upon; but the enjoyable feast over, we turn into our sleeping-quarters, and leaving ourselves to the care of Him 'who neither slumbers nor sleeps,' are soon in the realms of Nod, heedless of the bright pale harvest-moon shining through the latticed windows, with the honeysuckle making strange patterns in the shadows that fall upon our coverlet. $\circ$

It is an early-rising lark that is up before us in the morning. The martins, twittering in their rude clay huts above our window, have scarcely peeped out to welcome the sunrise ere we are doing the same. A jolly day's fishing is in prospect, for the wind bids fair and the fish are well upon the feed. Then we have some lady friends coming to Broadland to-day, and if we can but persuade them not to be fidgeting about, and wanting to pull here and there, and sing and laugh, our happiness will be complete. But ladies, for sure, are never so restless as when upon the water! They must gather bulrushes and reeds, and pluck the yellow iris and those lovely waterlilies! And they-the ladies-are irresistible. And what man is there who dares disregard their imperative demands?

On our way to the village station to meet them we encounter an individual whose 'doings' interest us. He is a little old man of sixty summers, at a guess; there is a dash of something superior about him. We edge him into a chat, and find him communicative. He hails from a neighbouring city: 'I'm from Norwich, sir, I'm Norwich bred and born. A good old city that, with its forty churches 
and its 100,000 folk; and a better people, take them on the whole, you'll not find in old England.

'What do I mean by that? I'll tell you, sir; there is not a more unclannish folk: they're open-hearted, free, and always ready to give a hand to an unfortunate fellow-citizen. I won't say more or you'll think I'm clannish.

'What am I? Well, I do anything just now; they call me the 'fern-man,' and it's ferns, you see, to-day I'm gathering. Here's lady-ferns, spleenworts, and prickly shield-ferns. Many folks have a taste for this kind of wild-plant; and what looks better in a dingy backyard than a nicely arranged fernery?

'You see, sir, it's like this. I wasn't brought up to this kind of thing. I am a ' comp.' by trade - a printer, you know - but getting my right hand crippled (see it) in the machinery, I was of no further use. I met with much kindness, but, you know, you can't live always on it - at least, I couldn't-and after turning Micawber for a time, I thought 'twas time to turn up something for myself. I was always 'gone' on botany, and natural history in general. So thinks I, when I saw some ferns in a hedge one day, here's just it; so, getting a 'ped,' I filled it, and leaving a bit of pride behind me, started business. I soon cleared out. And that's how one thing led on to another. In the various seasons I hunt for watercresses, ferns, primroses, sweetbriar, and other wild flowers, taking commissions for gathering specialties for cooped-up folks who have tastes akin to my own. Why, only to-day I'm taking home this bundle of dandelions for a herbalist, and this bunch of wild plants to a botanist, who particularly wants them, and hasn't time to come himself. I met with a stroke of luck not long back, I found a species of orchis, they named it Gordyera repens. It was growing amongst some firs; they said it was imported with the trees from Scotland. Where did the luck come in? Why, with the crown that followed!

'I don't confine myself to 'green-stuffs.' Anything in the way naturalistic that turns up I take it on. Oh! by-the-by, I've a splendid snake here. Here he is, I tied him in this little bag. I heard a funny squealing just behind a hedge. I peered cautiously through, and saw a sight that much interested me: it was a wretched frog that was protesting; this snake had got him by the leg. The frog was kicking in a dazed sort of way, as if he felt it was all over with him. One leg was down the reptile's throat, the other hind leg was free. It was really exciting to see; and I stayed to watch the finale, which came about eventually in the frog's going down, poor thing! And this swelling in the snake shows how far on his travels the four-legged reptile's gone as yet.' 
The squirming grass-snake is replaced in his bag, and the heavily-laden little man plods on again - and his tongue keeps equal pace.

'Natterjack toads and common toads I never pass by, sir, for many folks like them in their gardens and their greenhouses, where they earn their living snapping up the insects. Newts and lizards I've a market for, and the tenants of the ditches have to mind their P's and Q's when aquaria need replenishing.'

Much more does the old man say, which space forbids to detail.

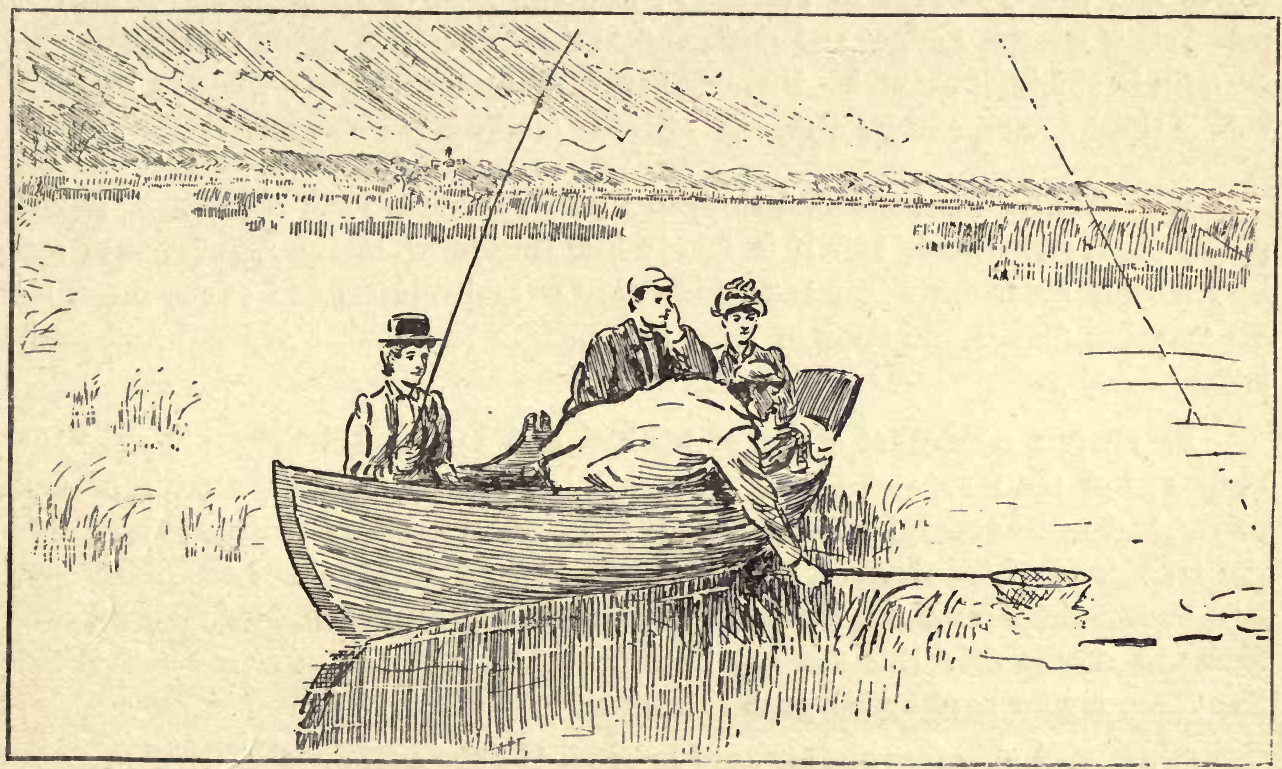

WELCOMING A PERCH.

After a jolly walk we find ourselves afloat. We shall not expect to see many bearded tits or wild-fowl or coots or moorhens, or to have the willing company of many a little reed-loving songster to-day, for other warblers in the boat will do the singing; and snatches of familiar boating-songs will be the order of the day, no doubt. And is it not well in every sphere of life that the ladies are more volatile than men? Why, bless you, phlegmatic man has much to be thankful for when light-hearted, hopeful, sunshiny woman throws her pretty shadow across his pathway! 
The plumy tufts of the now perfect reeds nod in the breeze, and the tall pokers of the bulrushes bend to peep at their reflex in the clear waters below them. And the waterlilies, spreading their great green leaves, and opening their snowy flowers, put the finishing touches to many a lovely corner of Broadland. We make for one end of the Broad, behind whose reedy margin rise low hills of cultivated land. The water round us has a greenish tint; into it we quietly drop our huge flint-stone anchors. The view from the stern of the boat is pretty. There is a maze of little islands, which look like floating flower-beds. Water hemlocks, water plantains, purple loose-strife, and the pink willow-herb show up their large green leaves and pretty flowers in profusion; and the pointed spear-leaves guard the pale-yellow irises. Sedges and reeds and rushes, with dark-green alders and willows, fill in the back-ground. Our tackle and rods are soon put together : groundbait is thrown over, and we seriously settle to angling.

We have, for our factotum, shipped a native, who at once becomes a ' guide, philosopher, and friend,' and it is due to him that much of the flightiness of our lady friends tones down into something akin to real interest and earnestness, for his amusing dialect and store of local information win their attention and their love of novelty.

He unreels much that others of his kith and kin have already told us of the birds and of the fens and fenfolk, although to him the days when the ruffs and reeves, and many another present-day rarity, were common, are nothing more than the traditions of his elders. Yet he has had 'sport in his time; why, bless yer, he'd known the Broads friz hard as wall-flints in the winter, and ha' seen fowl an' swans in oceans driv' this ere way by bad wather, and a flyin' round and round the place, reg'lar hard up for grub and water.'

'Once, and only tew winters ago,' he says, 'I done a stroke o' shootin' as many an old gunner would a' thowt worth the doin' in the old times. It had blowed an' snewed for a couple of days, an'-

'Theer, sir, yow had a splendid bite jest now-yew've got him! I towd yer so.'

We strike, and haul out a big slimy bream, but not before he has given a little bit of protest, and made his exit from his native haunts a warning to the friends he has left for ever, unless they be heedless, and share a like untimely fate.

'I wor sayin', sir, it snewed. Law! the hivens wor black as thunder-clouds, and the Broad wor kivered with a couple o' feet of ice. Old 'Prickle-back' Thacker an' me got leave tu du a day's shootin' on the ice, the gent at the Hall being a 
bit partial tu me; and we went up theer with our old 8-bores an' a hatchet. Up an' down the poor bards was flyin', and as soon as they seed the open patch of water, an' sum chaff we'd thrown in, a-flotin' on it, in they plumped. We wor a-hind a heap o' faggots; and if yew b'lieve me, we blazed away several times, pickin' up near twenty pokers (pochards), a dozen wild duck and mallard, several teal, and amongst 'em a number of rattle-wings (golden eyes), and a lovely black and white weasel-duck, what yow'd call a smew. We filled a sack, didn't say much about it, and sold 'em at a dacent figure at a Norwich poulterer's.-Yew've got a fish, lady! Now then, let me shove the net under; steady a bit-keep the line taut, now wind up a bit. Now we've got him! And as nice a perch it is as I'v seen for a wery long chalk. If it ain't a tew-pounder, my name ain't Sharman!'

Nothing more out of the common falls a prey to the allurements of our wellcleansed lob-worms. Bream-mostly under a pound in weight, chance-time one above it-a few heedless little roach, and now and then a perch, or a succession of them, make our floats dance and vanish. There is fun galore, 'tho' what is fun to you is death to us,' the hapless fish might tell us; even the squeamishness of the fair sex vanishes in the excitement of the pastime, and the most fugitive thought that angling savours of the cruel and the ungodly appears to have flitted also. May we not have felt like old Walton in his vindication of an angler's innocence?

'For so our Lord was pleased when

He fishers made fishers of men;

Where (which is in no other game)

A man may fish and praise His name.'

In the meantime Sharman has been most graciously communicative.

'Theer ain't much as'll beat fishin' when the fish'll bite, sir. And we ain't duin' hadly this mornin'. Why, I've took folks on heer afore, and fished the hull day out athowt a sorry scale comin' up. How many fish ha' we got in Broadland? Wal, le' me see, theer's over a score. I'll run 'em over. Pearch, yeller bream, roach, roud (rudd), silver bream, ruffes (tha's one yow now hauled in, Miss), minners (minnows), gudgeons, pikes (some on 'em whoppers!), tench, and miller's thumbs-them's all common. Then theer's crucian carp, and the 'tother carp, which is as artful as a lawyer, and trout higher up the river-them I know on. And I've heerd say theer's loach, and p'raps a few chub, an' maybe one or tew more, but I ain't seen 'em. An' seein's believin', ain't it? I ain't mentioned eels?Wal, yow doan't hardly call 'em fish. What are they, then? Why, eels, in course. Theer's tew sorts o' them. 
'Law, 'tis a pity we 'Norfolk dumplins' can't make good use on 'em when we've caught 'em. Seems such a pity to chuck a catch of three or four stun on the bank tu feed the flies an' rats with an' breed most fearful stenches. They tell me in some parts they make 'em a credit tu the fryin' pan. I doan't see why we shouldn't hev better kinds of fish introduced, suffin' as we ken eat. Jest yow try your cook with a couple of bream, sir; if she don't chuck 'em to the cat, and fry yew a haddock instead, my name ain't Sharman! Yew see they doan't fare tu know how tu make 'em tasty.'

'Fish are queer 'uns. They her whims an' fancies jest like Christians, and are a sight more knowin' than we think 'em.'

Such is a sample of our factotum's extempore lecture. The man seems a kind of talking machine and a Broadland encyclopædia in one, as most of your fen-folk are when fellow-feeling makes us kin. But once break through that thin crust of reserve, and edge them out of their monosyllables, and they unwind to an extent that is surprising.

Reader, did you ever escort a lass to the railway station after a day's frolic in the country? You know what packages went out, and what an increase, alas! came back again; such bundles of flowers and reeds and grasses, and what not. You were glad when your faltering footsteps reached the station threshold. Pity us, then, with a brace of them, with the weight of our own paraphernalia, and some of the largest of the fishes, for they've determined to cook them, cook them-mark you. And then those bundles, and-

Yet we have some pleasant recollections of that delightful August day in the Broadland. 


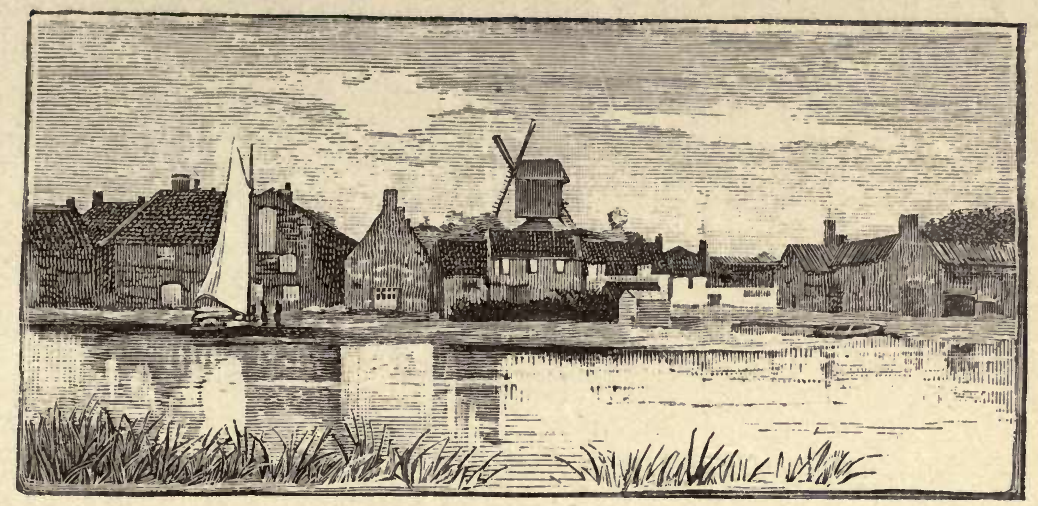

THE VILLAGE BY THE RIVER.

\section{SEPTEMBER IN BROADLAND.}

'When Autumn scatters his departing gleams, Warned of approaching winter, gathered, play The swallow people-'

-Thompson.

HE glories of the Broadland summer are on the wane; yet September is one of our most delightful months, and though the beauties of Flora are not so widely broadcast, Pomona is smiling upon her ruddy orchards. There is a decided change creeping over the face of nature, many of the birds of summer are on the move, and the sounds which greeted the ear in the longer days are replaced by a different order. The harvest is ended, the fields ares horn of their beauty, and the thatcher has all but completed his roofing in of the corn-stacks. The weather is yet warm and balmy, the sportsman is out with dog and gun in the stubbles, and Farmer Giles and Hodge are putting their thrashing-machines in working order. Much of the poetry of country-life is obsolete; the flail is no longer heard upon the thrashing floor, and the gleaners are among the shadows of the past. There is little in the hum of machinery to awaken the poet's muse. And behindhand Broadland has followed in the wake of the more advanced agricultural districts. 
An early September morning finds us hastening on our way into the 'Land of the Broads.' We are our own Jehus for the nonce, for the modern 'bike' has usurped the place of yacht and horse and railroad. There is much professed appreciation of the beauties of the surrounding country from the saddle of a 'safety,' but the temptations to hurry, the obscuring tendencies of dust, and the several other obstacles to observation that are obviously incidental to it, make such statements doubtful, for the eyes and the mind are too much preoccupied to allow them to wander far aside. One wants to dawdle and to 'mardle' (gossip) in the lanes, as the bees do among the flowerets, to extract interest from them.

We have turned our backs upon the sleeping town, whose streets have been handed over to the drowsy policeman and the sweeper. The town sparrows have only just hopped down upon the roadway, the late broods of house-martins are twittering in the doorways of their rude clay tenements. The shrill ory of the swift is no longer heard abovehead, and the swallows will be congregating to-day upon the elevated electric wires, discussing their approaching journey southward. As we glide along the 'turnpike' sounds of bird-life betoken that the feathered tribes are beginning their daily avocations. Snatches of song are indulged in by the thrush and blackbird, whose domestic cares and worries are again ended; and if that sweet mellow song we now heard is not the roundelay of the woodlark, we are very much mistaken.

The dew is still upon the hedgerows and the grass beneath them. The big nets of the geometric spider, suspended upon the thorny sprays, are beaded with diamond drops that sparkle in the sunlight, and the stubbles are interlaced and covered with the filmy flakes of gossamer. Yon partridges, hastening towards the shelter of the herbage at the hedgeside, are not well-pleased with the close-shorn fields.

If the foliage of the trees was beautiful when the year was younger, it is far from unlovely now, when tinted and bedecked with the colours of autumn. A few of the leaves have fallen, and many are fading, and will ere long become a part again of mother earth. The naturalist, to whom all life is dear, sighs and regrets that 'we all do fade as a leaf,' yet feels assured and satisfied when he remembers that a new life will dawn again when the snows of winter are ended. There are but few wild flowers enlivening the monotony of the hedge-bottom, in which the yellow bracken is spreading its big serrated frondage. The flea-bane dots the coarse herbage with yellow, and the clinging festoons of the great bindweed are hanging out their pinky-white flower-bells. The purple nightshade is flowering 
freely, and the honeysuckle above it is yet adorning the hedges with its sweetlyscented sprays. The hawthorn berries are assuming a ruddy hue, the old fir-trees behind them are heavy with their myriad seed-cones, while here and there the taller birches and oaks and ash-trees cast their shadows over them.

By the time we are fairly within sight of the Broads the country folk are stirring. The clanging of the anvil at the village smithy rings out clearly in the quiet morning. Faint blue smoke curls upwards from the low chimneys; there is scarcely sufficient wind to scatter it or to turn the sails of the quaint old mill in the centre of the hamlet. There is not a ripple upon the river that meanders slowly by, and in whose clear depths the houses and the white sails of the yacht moored at the little staith are graphically reflected. A couple of yachtsmen on the bank are preparing for their morning dip. A mile beyond us lie spread the waters of the Broad.

We walk our safeties uphill, staying a moment beside a stile to take a glimpse at a furzy knoll and the spreading landscape beyond it. We clamber over to examine a gaudy wild-flower that has attracted our attention. A wheatear starts up from a slight depression wherein it has been hunting for ground-loving spiders, perches daintily upon a furze-spray, flicks its tail and darts away again to some fresh location, making its white rump conspicuous in its flitting. There are a number of others which are congregating ere they make for the downs of Sussex on their way to cross the Channel. There is a host of linnets; small flocks of them are already working southward from the northern moors. Our home-bred birds are congregating. The bird-catcher evidently knows it. Yonder is one of the fraternity; let us 'beard' him.

He salutes us with a nod and 'Mornin'! gintlemen,' and then resumes the attitude of attention, with his pull-over cord in one hand, and the string which works his ' trigger-bird' in the other. The 'calls' of his caged decoy-birds have announced the arrival and passing over of a parcel of linnets. The man's face is all animation as he pulls the lever of the trigger up and down; and the little bird braced upon the end of it flutters its wings in order to keep upon its perch. Down go the poor creatures into the fatal space between the clap-nets, which are instantly pulled up and over upon them. Farewell for ever! sweet liberty and fair scenes of early days and friendships ! 


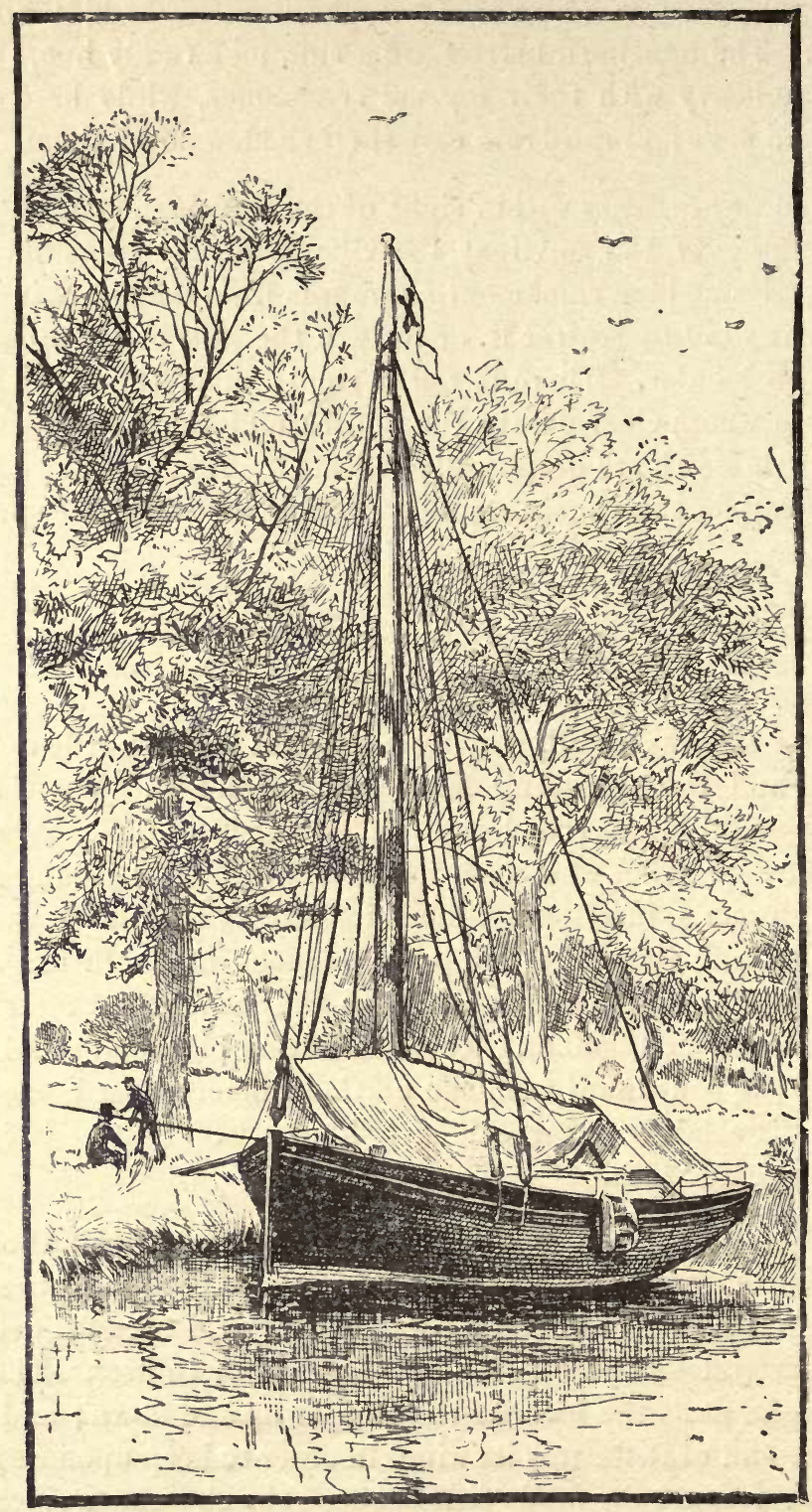

PREPARING FOR THEIR MORNING DIP. 
Let us describe the bird-man's surroundings and his stock-in-trade. Furzebushes and thistles dot the outlook for several acres. On an open space two huge oblong nets are so spread that when 'pulled,' by connecting cords and stakes, the area between them is covered by the turning over of the twain. Inside are spread a quantity of chickweed and other dainties beloved of linnets, which form his principal catches. Upon a couple of long twig-levers a linnet and a goldfinch are generally fastened. A piece of kid glove, cut something like a pair of braces, and known as such, is placed around each bird, and by means of an eyelet below, each is fastened to the stick. The jerking of these up and down attracts the passing migrants. Around the net are placed little sentry-boxes of cages in which flutter a well-trained series of linnets, goldfinches, siskins, and such-like, each of whom, saluting the wild individuals of its species, too often unwittingly lures them into a like captivity.

And now the man finds he has a tongue, and to a question or two gives somewhat evasive answers; but presently, over a well-filled pipe, thaws into conversation, and becomes communicative.

'What bards du I usually ketch? Wal, 'bor, it's mostly linnets that I'm arter, but I ain't perticlar if I can trap a few draw-waters (gold-finches) as well, which pay better 'an any others; aberdivines (siskins) an' redpoles-they pay for the ketchin' tu. But law! theer ain't neer the bards theer wor when I was a youngster, not of the sort as I want, anyhow. Why, I've ketcht eight an' ten dozen cock linnets in a mornin' where I takes only one or tew nowadays. I s'pose the choppin' up of fuzz-bushes by the knock-a-ball golfers ha' cleared out some of their breedin' places, I know for sartin they hev at Yarmith, where ketchin's about done for, and maybe us fellers, though I say it myself, have summat reduced the stock; and no wonder, when ye reckin up the hundreds of thousands we've trapped, say, for the last ten yeer. Look at them draw-waters-why, they've come as scarce as lion-shillin's where they used tu be as common as sparrers.

'But keep yow quiet; here's suffin a comin' '-And 'suffin' does come, but refuses every call and enticement to enter the fatal area; after wheeling round once or twice the parcel of wary birds fly onward.

'They've bin pulled at afore, and ha' growed artful. What du I du with my bards? Wal, I hev reg'lar buyers up in Whitechapel as takes all I like to send 'em, at so much the dozen. One feller takes every mortal thing I like to send him-song-bards, and any other sort as is stupid enuf to patternize my nets. An' I've ketcht a rummen or tew in my time. Theer's one or tew folks as collects bards 
in the town, and they're crazy for tu hev any queer-uns as I ketch, and pay well tu for 'em, they du. Lemme see, I've netted a Richard's pipit, a white wagtail or tew, several shore-larks, and three or four Lapland buntings, besides some as I can't remember theer names. It's like this, 'bor, we know the common ones, and anything as isn't common, why, it's oncommon. D'ye see? Then we make the best markit on 'em we ken. Some yeers ago I ketcht a bard as I thowt were a cur'ous linnet, and sold it for a tanner (sixpence). It throwed up a couple of earwiggles in the cage. What wor it? Well, I heerd arterwards as how it wor a barred warbler, and changed hands at four or five sov'reigns! That's what ye git for want of eddication-

'Jest a minnit, gents

Our catcher, who is successful this time, runs to make sure of half-a-dozen captives struggling under the nets. Four are let go again, and the other two are placed in a darkened store-cage, in which a struggling mass of birds are fluttering and rasping their bills against the cruel wires. Poor terrified wretches!

'Them wor hens as I let go,' he resumes, 'they bain't much use jest now, and never is, except I've got a order for shootin'-matches; then sparrers an' anything up tu starlin's cum in handy.

'Now I du set my fut on that sport as bein' in no-wise respectable; and ain't it aginst all reason an' feelin's of kindliness tu shoot poor things as ain't a atom of chance of excapin', except when sich fellers bang away as don't know one ind of a gun from t'other? I wouldn't let 'em have 'em, only I'm glad of the money they fetches. I wor a long time afore I cud swaller my squeamishness over ketchin' bards at all. Yow see that right hand's crippled; I got that some yeers ago in a thrashin' machine, and bein' no farther use for farm-work, and knowin' I must du summat, I bethowt me of doin a-this. Look heer, Jack Saunders, say's I (that's me, yer know), yow'll ha' ter $d u$ it, if yer likes it or not.

'When I seed my fust lot of bards a-raspin' madly at theer prison bars, aflutterin', poor things ! to find a way out agin, and shrilly pipin' in a scarified sort of way with wexation an' terror, I cud ha' let 'em all go agin. But I didn't, for I reasoned this wise. Thinks I, what is theer as we wear and use and eat and even sleep on as wasn't at one time part of some other bein' as we'd robbed or killed or sich like? Why, the wery butes I'd on my feet was once on the back of a hoss an' a bullock, and more an' one old hen wor kilt tu make that feather-bed!

'Then agin, thinks I, poor critters! yow'll be shet up in a little cage an' hung up in some stuffy alley or out of some slum winder, tu breathe unpure air, and 
niver see green-stuffs agin, but then yow'll gladden some poor critter's heart with your singin', remindin' 'em of yeers long gone by when they was country-folks theerselves, and makin' sorryful hearts forget theer sadness in the pleasant mem'ries of the past. And yow'll git yer grub for sure an' sartin. And so the squeamishness wore off. And here I am, a-tryin' to catch 'em still, and ha' bin these sixteen yeer an' more. I love the open country, and tu heer the jolly songs of the bards; I never hurts 'em, and I don't know as I'm worse 'an many another naturalist 'bloke,' for don't some on 'em ketch an' kill, stick pins through beetles, rute up the wild plants, knock over bards, or git others tu du it for 'em? I know this 'ere job is looked down on, but 'let him as is without fault hull the first stone,' and they ' mustn't chuck 'em as lives in glass housen.' So says I.'

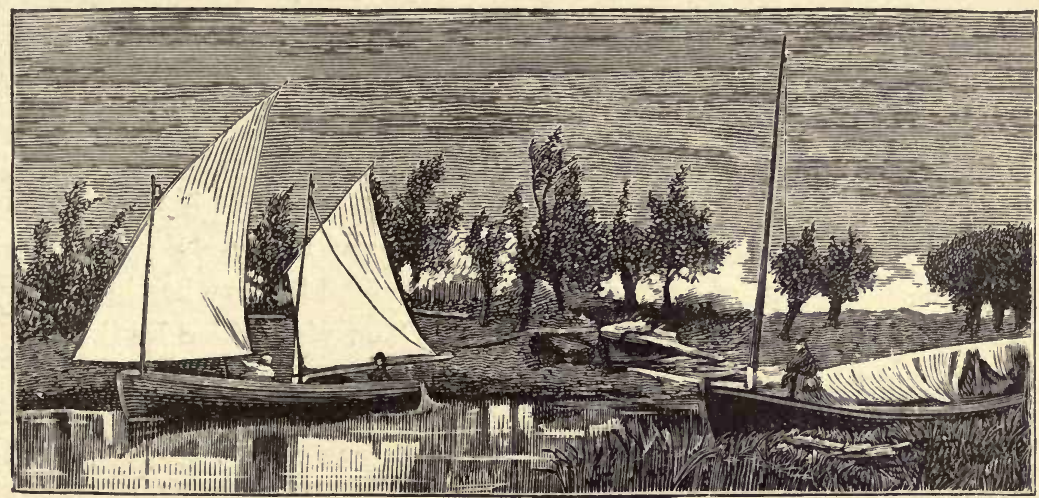

OUR LITTLE CRUISER.

Much more about larks and greenfinches and a host of others is told us of their respective value and qualifications, of their ways and habits. The man's calling and his environment all tend to make him a keen observer of nature in her varied aspects. He tells us of his other 'doin's'- how that he ferrets for rats and helps to trap vermin for the gamekeepers, and of a host of other 'odd jobs' that fall to his share in the circuit of the year; and that all play their part in the maintenance of ' hisself an' the old woman, and in keepin' 'em out of the workus.' His patter would simply fill our columns, if placed therein in detail. 
Leaving our 'bikes' in the care of the village innkeeper, we find ourselves at length by the limpid waters of the Broad. We have been not a little amused and interested in the droughty frequenters of the old 'Boar's Head,' some of whom have arrived there earlier than ourselves, whilst others have been dropping in as we are munching our cheese and biscuits, and sipping our glasses of - gingerbeer. Big strong fellows they are, with towy heads and tousled beards, whose lives have been spent at the ploughtail and upon the fenland. Their attire is more accommodating than picturesque, and more grotesque than fashionable. Fashions alter slowly and stand for nothing in Broadland, save when Mary Ann has a few days' holiday from her 'plaace,' and then she, in her less tasty than gaudy attire, becomes the transient envy of the village maidens. Our friends in 'wideawakes' and fustians like their beer, but generally have the good sense to avoid excess. There is the usual small and tall talk that seems incidental to the pewter-pot and the ale-mug. Old yarns are spun no doubt for the hundredth time, and it isn't all Gospel that is dispensed in the village alehouse, any more than it is in the city ' snug.' But the moral atmosphere in general is, fortunately, purer. The latest village intelligence is sifted and dispensed in between their tippling; and by the time their pots are empty each one knows that 'Cadder' Duffel is blessed with his twenty-third baby - that Farmer Stubbs' colt has broken its knees-and that the Squire's latest litter of puppies is a likely 'lot o' critters.' Much personal history has been raked over, and even the 'wrong doin's of Parleymint' have been rightsided by the village snob and tailor, who are here, as everywhere else, 'the most knowin'some old fogies' in the village democracy.

A trifling episode does much to vary this dull, monotonous, diurnal round of conversation. An itinerant quack-doctor drops in with his baggage; he is trudging on his way townwards, but is glad of a rest and a refresher to break the irksomeness of the journey. He is a keen, ready-witted fellow, with an eye to business; why shouldn't his halt be turned to some account? Straightway he begins to ' patter.' The host rests upon his elbows; open-mouthed, the unsophisticated rustics take in his lecture. A slight wink at us passes unnoticed by the others. In minutest detail, every ill, and many others, to which mortal man is subject is expatiated upon - the usual 'pains in the back, dizziness in the head,' and all the fearful catalogue-a hotch-potch of wisdom and eloquence, chiefly strung together from circulars advertising patent medicines. Burly men are led to believe they must be suffering from one complaint or another-or may do; and big freckled hands dive deeply to where coppers are known to be in hiding. Boxes of the magic pills, mostly concocted of soap and bread-crumbs, no doubt, are slipped in the places 
rendered vacant by them. As the quack politely departs he gives us a supplemental wink, which this time is caught and interpreted by the snob and tailor. 'I'm gormed!' ejaculates the latter, 'if that 'ere fellar ain't a frawd!' and bolts out to tell him so. But the 'frawd' is too far on his journey again to be in any fear of immediate retribution.

We are once again afloat, and bent on devoting the hour or so of our leisure to a jolly little sail in the trim ' lateener' that has kindly been placed at our disposal. With a favourable wind we sail up and down the Broad until we tire of the fun; and rare fun it is, too, to feel yourself spinning along as if the craft beneath you were a living thing-now this way and-now that, speeds the buoyant vessel, with the water hissing around your bows, and bubbling astern as you cleave the sparkling waters. You feel a delightful exhilaration, a pleasant excitement, as you dash past swaying reeds and nodding rushes, and the remnant of the water-lilies part to let you speed on and on. You forget awhile the cares that press heavily upon you in the toiling work-a-day world, and you return to them all the better able to cope with their stern realities. The coots and the moorhens fly into the shelter of the densest reeds, and wonderingly hold their peace as you bear down upon them, and mayhap scandalise you with returning confidence. But a continuity of pleasure, like that of work and worry, becomes wearisome at length; and presently we glide into a secluded nook, lower sails, and make the painter fast. We step out upon a low-lying fen. We have promised to take home a few Broadland plants to a botanist friend of ours. Here before us they lie, spread in confusion; unfortunately most of them have done flowering, and are past their best. We gather a few that we may, and may not, get thanked for. Here is the marsh cinque-foil, one of the sundews, the marsh veronica; some half-a-dozen others complete the list, for before we've had time to travel far across the shaking bog the weather has assumed so threatening an appearance that it is deemed advisable to make for the shelter of an old boat-house at a not far distant corner of the Broad. Away over the ruffled surface we glide, reaching the tumble-down place only just in time to avoid a pelting shower.

We have seen but few birds to-day. Rapid movement is, of course, prejudicial to observation, and is anything but appreciated by the quiet-loving creatures whose haunts we are intruding upon. A few late swallows are still darting up and down; but they, like their prey, have become perceptibly scarcer. Many of 
the sedge-birds have taken their departure; but while the soft-billed species are sensibly decreasing, hard-billed seed-eaters are en evidence. The whistle of the greenfinch, the pink pink of the chaffinch, and the familiar call of the linnet, as small parties pass overhead, are heard from time to time. There is a marked absence of bird-song. There is a decided quietude in the outlook, too; there are fewer yachts, and the bulk of the anglers have already put their rods aside for the season, and have shouldered the gun instead. The unhappy coveys of partridges are faring badly; while the corn was yet standing they had a safe and ready retreat from many of their enemies, but the stubble is cut so short that it offers them

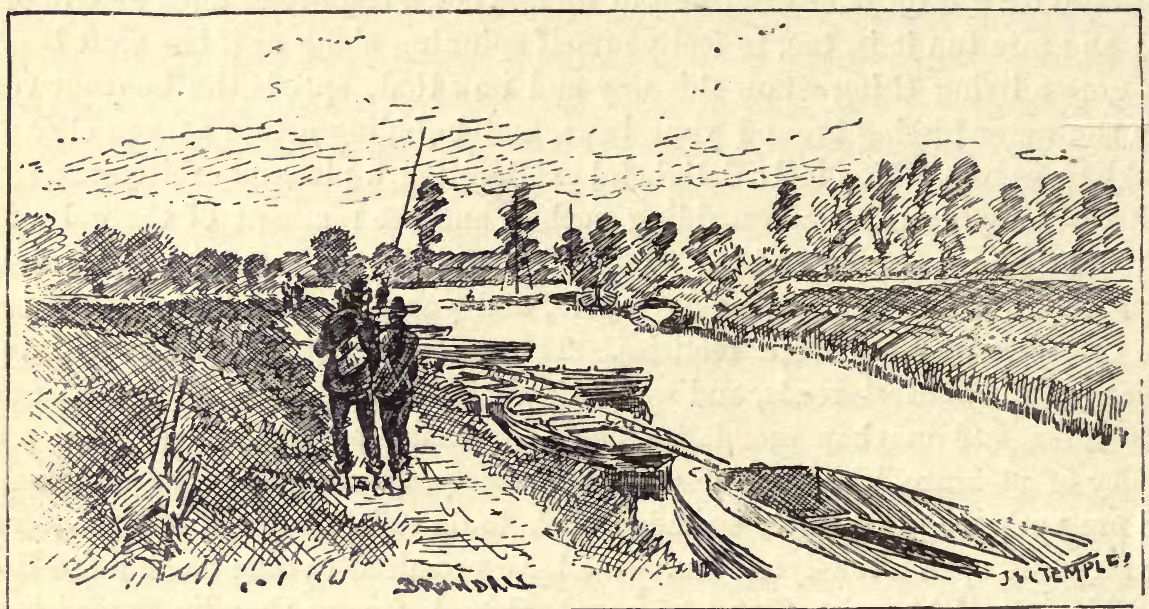

DISCIPLES OF IZAAK WALTON.

a very poor hiding-place; and their worst enemy is out afield in search of them. In the daytime they are glad to skulk in the groves and covers, and at night, for fear of marauding animals, they seek the open. The report of the gun becomes a familiar sound.

The boat-house is a rude structure, and in a state fast verging on decay. Through a hole in the roof an alder is pushing its leafy branches. In amongst the thatch the sparrows often make merry. A pair of marsh tits are flitting and scrambling amongst the rafters; they are in quest of hiding insects.

But we are not the only temporary tenants of the old shed; a big, brawny fellow, with a game-bag slung beside him, from which the brown head of a wild 
duck is protruding, has arrived before us. His costume betrays his avocation. He is a game-keeper. Like most men who lead a lonely existence, he is reserved and cautious, but like them, when once thawed into conversation, becomes communicative enough. It is some minutes before we are on such good terms; we silently watch the downfall together. Reassured by the quietude, the waterfowl venture out again into the open, grebes and their striped progeny, and coots with a younger generation nearly as large as themselves, and a whole family of moorhens paddle out from the reed-clump, some to vanish in the one opposite, the remainder to dip and play and fish until disturbed again by our unwelcome presence.

'See them starlings?' our new friend queries, pointing to a huge flock comprising some hundreds wheeling and manœuvring in a most well-timed and marvellous fashion. 'Well, I'm goin' ter give them what cheer 0 ! this evenin.' My guv'ner ha' suffered enough from them a-settin' on the reeds or roostin', that he says I must du some execution among 'em. Yow'd be astonished at the damage they du a-breaking down big patches of 'em. Theer's at least a quarter of an acre spiled a'ready in that patch in front of us. I doan't like wholesale slaughter, but a feller is paid tu du his duty. Yow'll think it funny, but I like 'em for eatin' as well as I du any bird as is a-flyin'! I skin 'em, cut their hinder parts away, and bake 'em in a pie. Some of them poor rogues 'll be in a pie to-morrer. That's the one redeemin' feature in the business.

'I git larfed at for some of my notions. I'm teetotal; that's somethin' new hereabouts in a gamekeeper, not as I know many on 'em as are drunkards. I doan't want ter become one, so, thinks I, pervention's better 'an a cure. My class, yow know, tu often get a downright love for killin' almost everything they come across. They think they're doin' theer duty, and so they kill every mortal thing as they imagine is likely tu du theer game birds a mischief either in the egg or feather. Law, gentlemen, we've got credit for doin' the biggest mischief in the way of wipin' out our rarer birds - and with some degree of truth, I'll allow ye. Lost British Birds * ha' put down that tu our credit. Theer's a book, you know, of that name jest published. Well, I was a-readin' it and thinks I, Jack Manly (that's me, yow know) ain't so bad, I guess, as some of his neighbours. No more is his master. He is doin' his best tu presarve some of the species, and I aids an' abets him, for, as I've thought these yeers past, what a pity it is that our native races of birds should be wiped out as they are. Theer's so many causes a-workin' against'em. Drainage and cultiwation - then them abominable Cockney sportsmen as blaze away for killin' sake only, from sparrers up'ards, then specimen hunters, 
as have collections-too many on 'em neither use judgment nor common-sense; they'll spend a hat-full of money, and du anything a'most tu get a rare 'un in order tu stuff it, and shet it up in theer crowded cases. More's the shame so many of my fraternity encourage 'em, and bows the knee tu 'filthy lucre,' and glory in killin' the poor doomed critters beside.

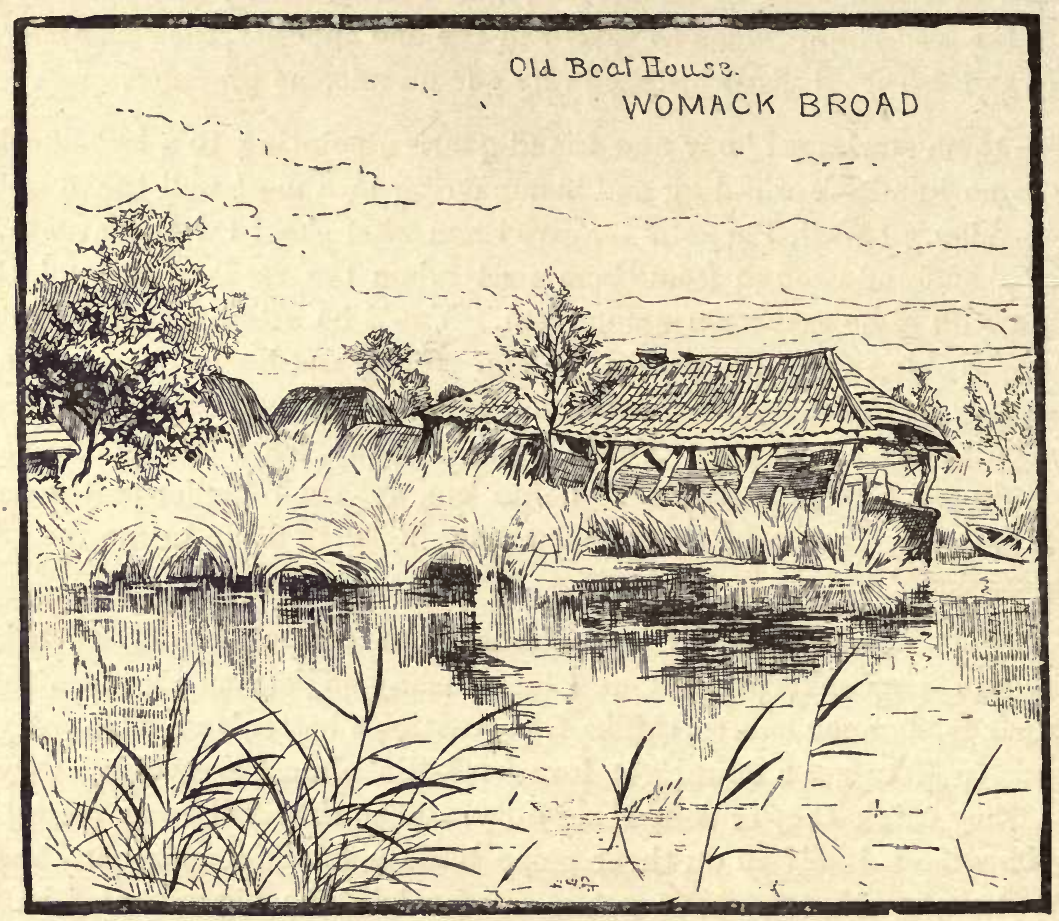

- Then the 'wermin' we're supposed tu slaughter. Some makes awful mistakes about them. Of course, we're paid tu du suffin', but it's left a great deal tu our discretion. Sorne uneddicated, stupid fules are dead-set on barn owls. Why, never a better game preserver cud theer be. It's rats, gentlemen, rats, as du more mischief tu game than anything else. And owls is mortal enemies tu 'em. Then where comes the sense of killin' them? Every little hawk is outlawed. Give me plenty of kestrels, says I-look! theer go a couple yinder !-and I'll wager the field-mice 'll not prosper. Kill yer kestrels, foster yer field-mice, and where's yer 
corn-stacks? The poor farmer is the greatest sufferer. Then theer's bigger birds of prey as is all but extinct with us. When I was a nipper, hen-harriers and marshharriers wasn't so scarce as now. Now, I think hawks doan't du near the harm tu game as they git credit for. I think, like Canon Tristram, that 'they're the perlice of nature'-runnin' in, in more ways 'an one, the weaklin's and the sickly. Healthy game knows how tu take care of theerselves most often; if landowners an' keepers was only tu read up and obsarve and measure theer brains aginst prejudices, things 'ud alter summat. But they doan't, and so they kills an' kills, and thus cleer out the innercent critters.

'An' then, see what improvements ha' bin made with guns: folks must hev breechloaders - an' what chance hev birds agin 'em ? It's bang ! bang! as fast as yow like. More's the pity the old muzzle-loaders hev had theer day: they did give 'em a chance, and theer was some excitement when yow had to load an' keep yer eye about yow while yer did it. Disappointment in shootin', from the bird's sometimes escapin' yow, made yer ultimate success all the more excitin' an' pleasurable. Yow see, I still sticks to my old muzzler.

'Protection's doin' good here, gents. We've more ducks 'an ever; snipes ha' bred this yeer on the fen yow was walkin' over, and not far away was more 'an one nest of ruffs an' reeves t' year. I doan't mind tellin' yow, 'cos yow ain't likely ever to disturb 'em. A pair of bitterns laid theer eggs there tu, but some lout of a wisitor found 'em. I copt him jest as he'd blown 'em. But I cracked 'em for 'im, and done a'most as much tu that stupid head of his. Not as I did right, but the law would only ha' fined him for trespass. Theer, thinks I, I can dispense better justice, and du it summarily. He wanted to square me with half-a-sov'rign. I took it, bless yer, but when I chucks the half-a-nicker in the broad, yer should ha' seen him look! I guess he oan't come here agin in a hurry.

' This slaughter, in course, is good for some of the small birds which ha' become a nuisance, sparrers in pertikler.

'Look 'ere, gents, theer's a lot as want right-sidin'. Why doan't the law protect birds' eggs? Ain't egg-collectin', for instance, thinned out the different plovers? Look at yon pewits. Time was when we'd thousands bred here: thousands of eggs was taken. Now what a sorry few theer are. What more useful bird can yer find, as wipes off worms an' grubs as they did? Then what is theer nicer than seein' all sorts of characteristic birds around yer? 
'But law, 'bor, 'tisn't no use a-talkin'; tew much of the mischief's done. Avocets an' harriers, black-tailed godwits, spune-bills an' bitterns ha' slipped us, only stragglers turnin' up at intervals. In yon alder carr, I've heerd my dad say, 'blue dorrs' (black terns) bred in his younger days by hundreds. We only see now a few in spring on passage.

'And yet I live by slaughter! Well, gentlemen, that's my callin', sure-ly. But though I du raise partridges an' pheasants, I use a little common-sense in what I point my gun at. And du I believe in the wholesale slaughter of game birds? Wal, I doan't see no harm in it any more 'an killin' chickens, for ain't they more 'an half domesticated, and bred a purpose?'

A half-hour's chat with this strange conglomeration of philosopher and keeper leads to many other interesting topics, but time is on the wing, and we say goodday to the honest fellow. The shower has passed over, and nature has assumed a most delightful aspect. We row our boat to her mooring-place, for the wind has failed us. An aged fenman is examining his eel-set as we jump ashore, and we fain would edge him into gossip, but the wing of time is still fluttering. The loud boom of the keeper's gun bespeaks the discomfiture of the starlings which have, unluckily for themselves, wheeled within range of his 'fowling-piece.'

A bunch of wild fowl pass overhead in hurried flight. A wren chatters on a sallow stump beside us, a weasel vanishes in the undergrowth at a hedge hard by it, and a couple of swans are probing the muddy bottom of a little ' beck' on our left.

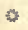

$\circ \quad 0$

$\Leftrightarrow$

。

.

s

$\emptyset$

We drop in at the 'Blue Boar' to enjoy a late but welcome dinner. We are this time sole occupants of the sanded parlour, save for the presence of the host himself, who has much to ask and much to answer. And what appetites we've been acquiring! Two hours later and our steeds are in their usual places in our homes in the busy town.

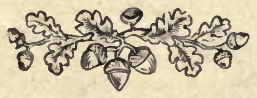




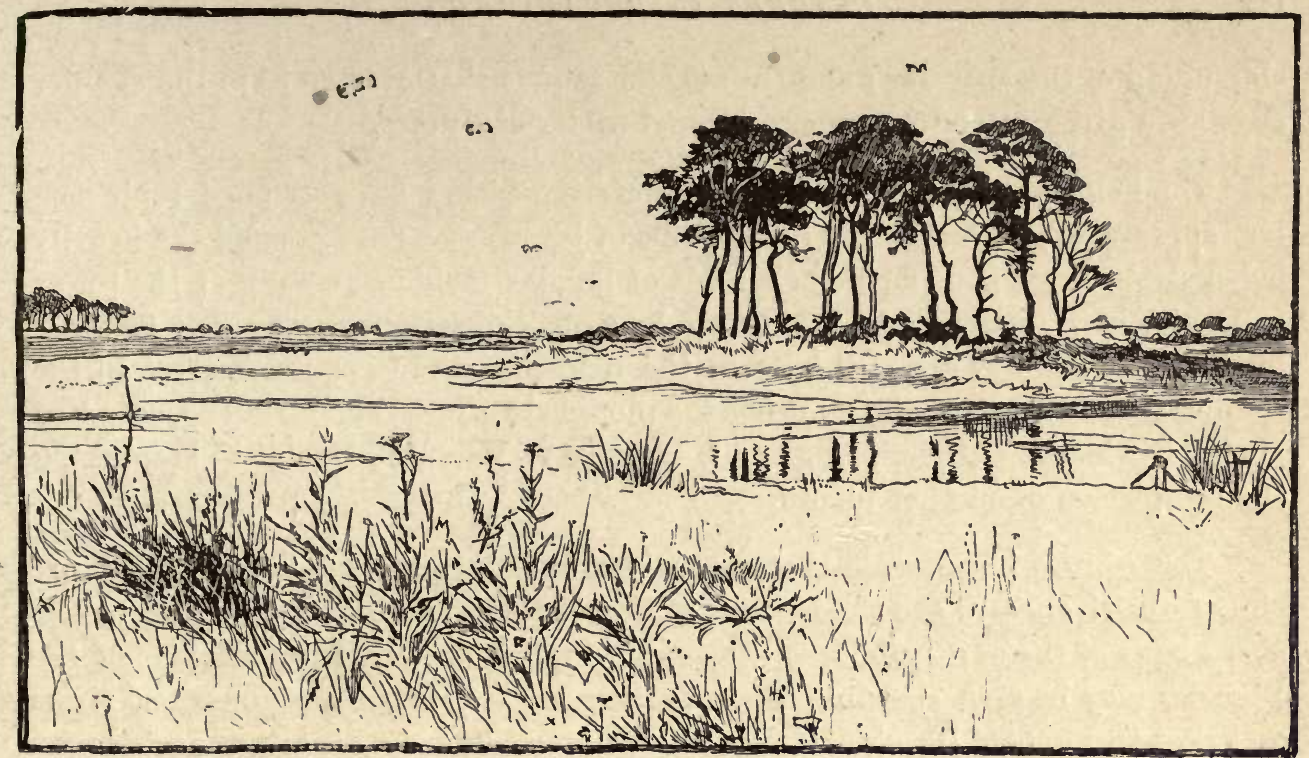

'THE HORNPIES' LEAD.

\section{OCTOBER IN BROADLAND.}

'Along the woods, along the moorish fens, Sighs the sad Genius of the coming storm. a 0 The wanderers of heaven, Each to his home retire, save those that love To take their pastime in the troubled air, Or skimming flutter round the dimply pool.'

-Thomson.

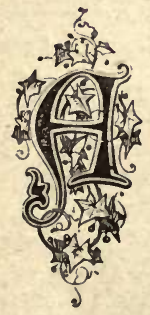

DECIDED change has crept, almost imperceptibly, over Broadland, and the face of nature in general. The eddying winds of autumn are making inroads among the 'sere and yellow' leaves that tint the hedgerow and the woodland, but which are yet beautiful to look upon even in their decay; the approach of winter has already made its influence felt among the tribes of earth and air. The summer birds are entirely missing; the chinking notes of the redbreast become almost as familiar as the 
chirruping of the sparrows; and the sweeter sounds that greeted us in the sunnier days have given place to harsher cries and wilder call-notes.

The holidays are over; the seaside watering-places have assumed their normal appearance; no longer the huge trains of joyous excursionists and the heavily laden steam-boats pour forth their loads of holiday-making humanity; the towns and cities have settled down again for a long spell of serious work. The dwellers in the quiet country are still busy in the fields, for a prospective harvest in the coming year demands their following the ploughshare and the harrow. Contented Hodge is whistling at the plough-tail, his merry 'Who-oaa, Dobbin!' bespeaking the completion of another furrow.

The white-winged craft that recently crowded the silent-flowing river are absent, the river-ways and the lagoons of Broadland are no longer ploughed by the sharp bows of the swift-gliding yachts-nothing but the huge tanned sails of the wherries may be seen speeding their devious ways among the sedge-lined rivers and reed-surrounded broads. On many a sloping shore the dismasted yachts may be found, there to remain until another springtime shall see them spick-and-span, ready to glide down again into their favourite element once more.

We shall have a quiet run-up to-day, and it is a strange little craft in which we hope to reach the Broads.

'Though I say it myself,' says Skipper Bessey, 'there ain't her likes on the Broads an' rivers for miles around, and there ain't another as is built for the selfsame purpose--and let get her clear of the town, and you'll see what a merry little thing she is!'

Our skipper is an eel-merchant, and as such has been known to the fen-men far and near for the last thirty years; hundreds of tons of eels have passed through his hands. Our vessel is simply a big ship's gig, with a streak or two added to her height, her sharp stem and stern and cutter-rig giving her an exceedingly rakish appearance. At the fall of the year, when eels are 'running,' and the eel-catchers are busy with their eel-sets, up and down she plies, going empty, returning full, sometimes with several hundredweights in her 'well.' Fore and aft the craft is buoyant; indeed at the stern is a famously snug cabin in which the skipper and his man make comfortable when on their strange voyaging to and fro. Midway the vessel is one huge tank, the sides of it being perforated with innumerable holes for the free ingress of water. What a squirming mass of living things will there be below-decks on her return! 
It is blowing stiffly as we reach the open marshland; we have a flowing tide and a famous south-easter, which strengthens into half a gale ere we have been many miles on our voyage. How the trim thing spins along, with every stitch of canvas crowded on-mainsail, topsail, and jib !

Several wherries are speedily overhauled, fast as they are sailing, although with shortened sail and with their lee plankways under water-our vessel is well ballasted, and our worthy skipper knows her capabilities, and we fancy is amused at our slight uneasiness, for now and again she heels over somewhat unpleasantly. The marsh-houses, the pump-mills, and the remnant of the cattle on the marshes flit quickly by, and a bubbling eddy of white foam surges behind us. The wherrymen salute us in their rough pleasant way as we pass them, and throw out not unpleasant eulogies on the white-bearded skipper and his dashing 'Polly.' But the wind shows signs of strengthening, and it is thought best to strike the topsail. Yet we tear along with undiminished speed.

'You was axin', sir,' Bessey resumes, with his hand upon the tiller, 'about them eel-sets. See yinder's one, hangin' on stakes tu dry; it's old Billy Nicholls'. Theer's old Billy hisself in the stern-sheets of his houseboat, a-washin' hisself. It's time he had a scrub, I reckon; but law, 'bor, you can't tell mud from sun-tan on them old fellars, they get so coloured up by strong air an' sunshine that mud an clothes an' men seem all of a piece.'

'Mornin', Billy!'

'Mornin', Bessey!' returns the old man of the muds, 'give us a call on yer way back.'

'All right!' replies our skipper, and keeps on.

'We was talkin' of eel-sets, sir, you know as well as I do that in the fall of the year myriads of eels return to the sea, from whence they came in springtime as tiny elvers no bigger 'an darnin' needles. Some big naturalists tell us as how these older ones don't return. I beg to differ, for what's them as we eatch in springtime a-working up the rivers? Anyway, in September an' October they take a fit for a sea-trip, and your Broadman knows it, and 'tis to his advantage to stop 'em. So he just does his best to do it. What with babbin' and pickin', much is done; but for whackin' hauls there's nothing to beat the 'sets.' In the day our eel-man does his snoozin', at night he keeps his wits about him. His eel-set,stretched across the river, must be watched, or passin' craft would spoil his little game. As you saw by that eel-set as was dryin', it ain't much unlike a trawl-net. Like a 
wall of network the fore-part's placed athwart the stream, corks keepin' the top afloat, lead sinkers keepin' all smart below. What about the wherries cuttin' it? Wal, it's like this, there's two or three lines fastened to the top line; these run through blocks fixed to stakes in the river bottom. It ain't a warm job always, to keep watch at night, you think; but ain't your eel-bloke as tough as most folk? and ain't his kettle of hot tea allers on the hob? If a wherryman looms up, he

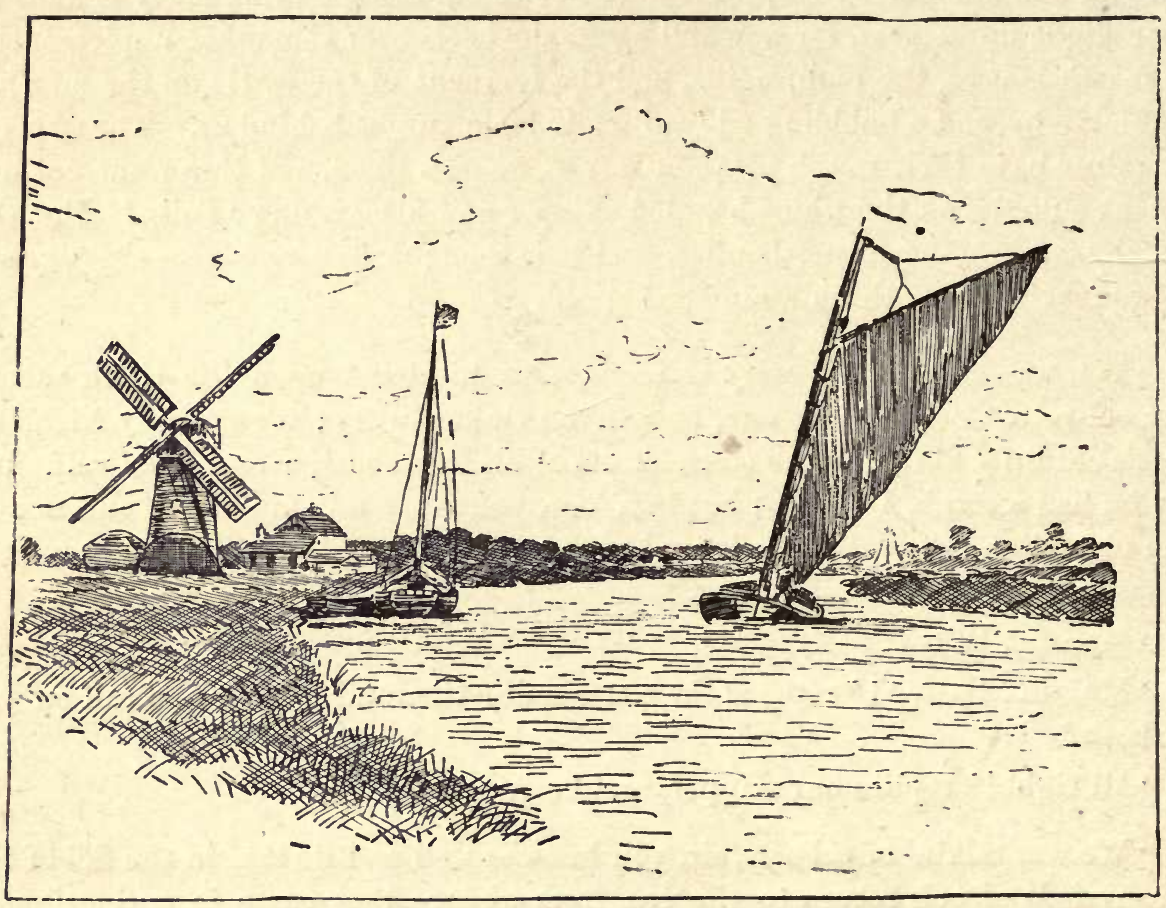

A FAIR WIND AND A FLOWING TIDE.

sings out to the t'other, who slacks the rope, pulls the lines, and down goes the top line, and there you are. Wherrymen know where they're set as well as the eel-blokes do, and t'ain't often as damage is done.

' Three or four openin's in this wall of net have long eighteen or twenty feet purse-nets attached, which, as you saw, are kept open by means of hoops, fastened to 'em. These 'pods,' as they term 'em, are laid and staked down-stream, their positions bein' marked by floats. Funnel-shaped fixin's inside, of course, make it 
awkward for the eels to get out agin. Return tickets ain't issued, 'bor, you may lay your hand to your heart on that. Sometimes they do well, sometimes badly; dirty weather an' a wanin' moon suits the business best.

'But come down, sir, afore you leave us; breakfast's ready, an' don't that kettle of tea smell just refreshin' an' delicious?'

s

st

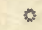

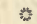

We leave the eel-merchant getting ready to resume his up-river voyage, for we have been moored to a staith while breakfast was being discussed, and much fish and folk-lore with it; we wish we could have invited the reader down into that snug warm cabin, and surely he would have relished the humble meal of brown bread and cheese, and enjoyed it none the less for the novelty of the situation and an increased appetite, nor have hesitated to wash it down with a basin of steaming, milkless tea.

We make our way along the river-bank towards the little brick bridge which spans the stream. Our eel-man has 'shot' it, and with upraised mast and sails has again caught the breeze. How the wind sways the quivering reeds to and fro! now bending low as it strikes them, they lower their woolly-head tufts, as if some giant reaper had drawn his scythe through their slender stems, but a moment after they have lifted again, to be swayed in another direction. Like the troubled waves of the wild North Sea, they are incessantly in motion. Their dry leaves rustle like the sound of shingle thrown up by the curling sea-waves. A heron rises with startled scream from a ditchside, and lets fall an eel as he mounts upon his great grey wings and takes to flight; a moorhen runs in a skulking manner upon the broken sedges that line the ditch-margin, jerking its funny white tail-feathers, and then vanishes in a clump of rushes. Nature has assumed a somewhat desolate appearance. A pavement of decaying leaves marks where the water-lilies spread their summer-time beauties; the iris, and many another characteristic Broad-plant are flowerless, and leaf and stem have become yellow and shrivelled. The Broadland botanist has all but discontinued his rambles, but has plenty to do in the long evenings in arranging specimens he has already collected. The alders and willows shake their decaying foliage in the blast, and many a leaf falls into the débris that has been blown in a tangled mass beneath their overhanging branches. The swans, with their still grey cygnets, pay scant heed to the fury of the elements. A flock of wild ducks pass overhead, and yonder long-billed birds, dashing by sideways to the wind, must be curlews, their weird, mellow call-notes unmistakably proving 
our conjecture to be correct. A puff of smoke from a bunch of reeds on the rond by the river is followed by the fall of one of their number. The report is from none other than Jim Trett's fowling-piece ; her 'bark,' as the fenman describes it, is unmistakable, and out from his lair the old man stalks, and retrieves his fallen game. We would not disturb him, but the good fellow seeing us, beckons us towards him.

'That's a dinner for the old woman tu-morrow' he informs us after a shake of his horny fist and the usual salutation. 'Some folks be tew pertikler, 'bor, and tell yer curlew ain't grand eatin'-but they doan't know, yer see, it's jist becos they've eaten 'em when they wasn't in their prime. D'ye see ? This'll du, 'bor, for it's a young'un, an' jist off the northern moors where 'twere bred an' born, its grub was lob-worams an' insex an' other bog-livin' critters. I've heerd my old dad say as how

'A curlew, be she white, or be she black, She carries twelvepence on her back.'

Not as it's worth a bob tu me, 'bor; anyway, it ain't spiled it's flavour yet, as it would sune ha' done down at the sea-coast on a salt-water diet. Lay yow down, look kedgey! (lively), and mind that pulk-hole! (mud-puddle).'

A loud report follows the old man's 'sight' down the long, bright barrel, which he has been loading during his eulogy on the curlew. This time a lapwing is slain, and as we peer through an opening in the reeds we see the poor thing stopped short in its flight, turn over, and with extended wings fall like a clod upon the rond, from which it rebounds several inches with the impact. Jim Trett evidently knows well the 'lay' of the country, and that certain spots are used as 'leads' by various wild birds.

' Here, 'bor,' he resumes, ' hornpies (lapwings) or pe-weeps, as some call 'em, gin'rally lead this time o' the year. Arter feedin' on them meshes (marshes) behind them fir-trees yinder, they cum back in the mornin' tu the uplands tu preen theer plumage an' nap till nightfall. Here cum tew or three more. I'll whistle 'em.'

The fellow's wrinkled face puckers up as he imitates the hornpie's familiar cry. But though they answer to it, they fly wide of him. We leave him to his own devices, and make towards the Broad, after promising to drop in at eventide to discuss the merits of an 'old hernshaw (heron) as he'd kilt the night afore on the meshes.' 
The breeze has upset Jim's arrangements for the day-had the weather been different he would have been out roach-fishing, with a gentleman who is keen upon the pastime-as it is, this angler, he informs us, had gone to the 'Fenman's Shelter,' and Jim, as we saw him, had made the best of matters by 'airin' old Peggy,' his favourite fowling-piece, 'an' shutin' for what he couldn't arn'--his dinner.

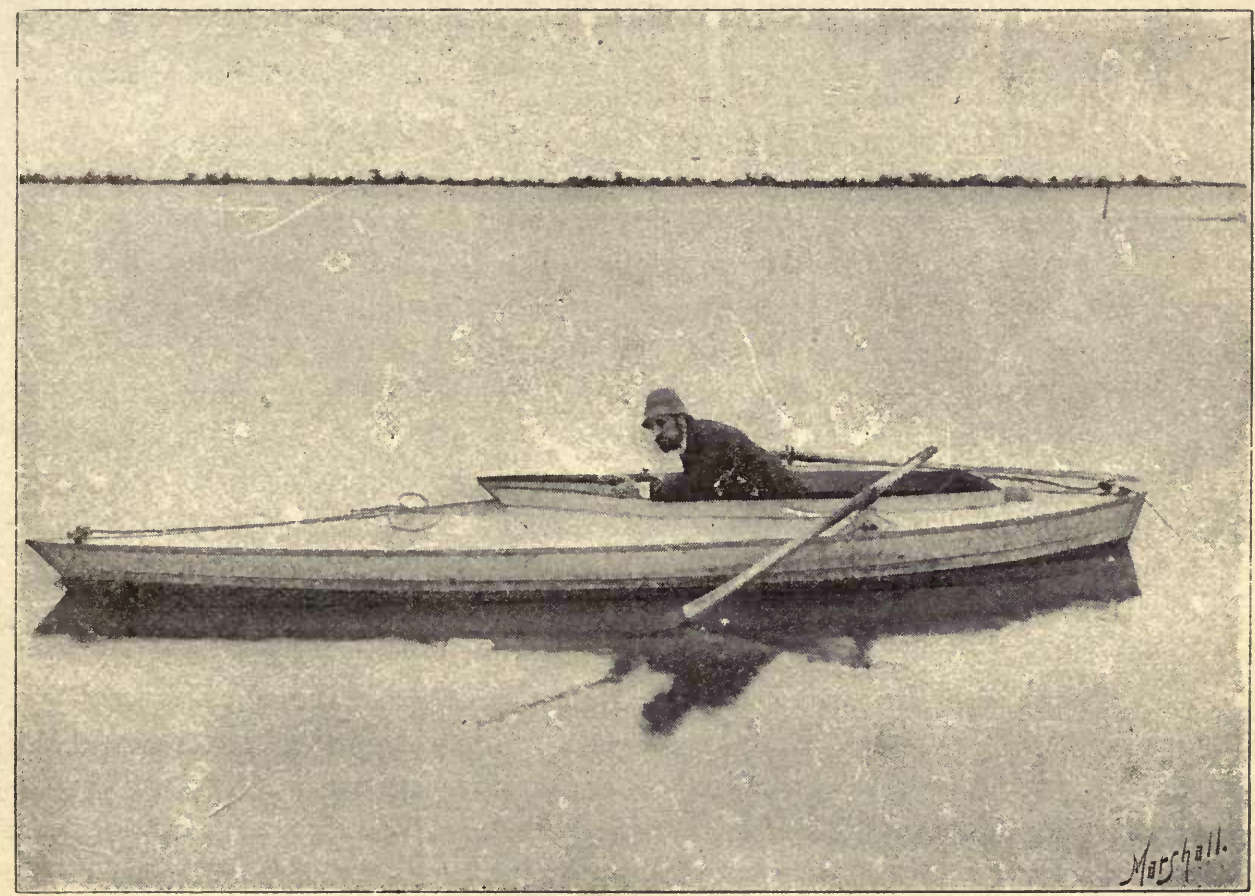

THE WRITER IN HIS PUNT.

Dropping in at the 'Fenman's Shelter,' we find the aforesaid roach-anglera plump, well-nourished, fussy gentleman, who seems alternately amusing himself with sipping a mug of ale and munching biscuits, reading a week-old 'Telegraph,' and peering in a fidgety sort of way out of the window at the weather. We are soon on a friendly footing, and the little man waxes exceeding chatty. 
'A rum fellow is that Jim Trett,' he remarks, when the weather and divers other subjects have been commented upon, 'and he's but atype of your unadulterated fenmen, who, alas! are a generation which these days of breechloaders, railways, drainage, and School Boards will soon supersede by a mongrel following. 'The fashion of this world passeth away,' I've heard our parson say, and it's a downright pity that your fenman has been included in the category. Education in particular is playing the_- excuse me, sir, I'd nearly dropped an old-fashioned English word with a ' $\mathrm{u}$ ' in the middle of it,_- havoc, I mean, with their strange superstitions; it is weeding out many of their queer, old-time provincialisms, and will some day convert their quaint Norfolk dialect into dull, terse, unmelodious English.

'In Marshall's 'Rural Economy of Norfolk,' written over a hundred years ago, he tells us that 'there is an alertness in the servants and labourers of Norfolk which I have not observed in any other district.' Then he says a lot more, and in contrasting them with their Kentish duplicates, makes regular models. of them as to manners, gait, and air. He might have been a Norfolk man himself. Now, I don't go so far as that if I am to compare your Norfolkese of then with their descendants of to-day. I'll grant you it will be difficult to find others to beat them at honesty, sobriety, and workishness. Times have altogether altered, too, since then. A hundred years ago Hodge was a boarder with his ' maaster,' he was bred and born on the 'faarm,' worked there all his days, and 'deed' there, and perbaps was happier on his five pounds ten per annum, and his board and lodging, than he is to-day. Perhaps not, for he's certainly freer to-day; he has his franchise, and can please himself in his choice of masters-but then, increased pay doesn't go for everything - for if he gets thirteen shillings a week, there has been a corresponding rise in what he has to spend. Times have gone against him, and machinery and foreign competition have seriously handicapped him. Many a fine young fellow's had to budge, and emigrate, go to sea, or find a billet in the overcrowded towns. Those who follow the sea, and alternate it with work ashore, seem to do fairly well; but a fisherman's calling is an uncertain affair. Many of the young strapping fellows are now following the North Sea herring fishery.

' Here, landlord, bring us some eggs and bacon, and a jug of coffee.' So orders our talkative friend.

'While we're discussing these matters, we'll improve the time, and ere afternoon has arrived the wind may have dropped a bit. Just look at that troop of larks flying over! They're Norwegians immigrating to our less inhospitable climate for the winter. 
Several flocks follow in rapid succession; a number of wild geese are discerned high aloft; and on a hawthorn hedge across the 'pightle' (small field) a number of fieldfares are seen busily plucking the ripening berries; and the note of the redwing is heard.

'As to superstitions, there's a lot of queer notions still afloat-(thank you, landlord)-Now then, sir, help yourself. You can't get fen-folk to do business on a Friday - those who follow the sea won't cross the bar, either, on that day, if they can help it; and as to walking under a ladder, why, it's equally unlucky. Primroses and poppies carried into a house are both bearers of bad luck, and for a cuckoo to fly over it, well, they'd as lief see the father of lies do it. Don't meet a cross-eyed party when you go to market; better stop at home. See three cuckoos on a walk, and you'll have a death in the house ere long. Someone is sure to die if peacocks' feathers are brought into the house. The hoot of an owl is more than uncanny; a red bee flying in at the door or window portends the arrival of a gentleman; a white bee signifies a lady.

'I could tell you a lot more. See! I've quite a note-book full of folk-lore. But the bacon's getting cold. Now then, landlord, some cheese and biscuits, please.'

'Believe me, faith in witchcraft hasn't yet died out, and the 'evil eye,' without a doubt, blinks at times.

'Did you see the landlord spit on the floor just now? He no more wanted to than I do; that white horse driven by the house was the innocent cause of it. It was lucky to expectorate.

'Our landlord is known as 'Loper' Grey. Ask in the village for Nathaniel, and few will know him as such. Lope is Norfolk for stride, his long legs have earned him his cognomen. Nicknames are all the go in Broadland; some peculiar or curious personal characteristic, or even some exploit, irretrievably christens a fellow. 'Prettymouth' Hewitt, 'Boxer' Brown, 'Grumpy' Johnson, 'Cadger' Read, and a host of others might be cited. If you want to find a village notoriety, make sure of his nickname rather than his family one, for it may be he's known only by the former.

'As to dress, there's as much canvas and fustian about the Broadman as will cover him, and a broad-brimmed felt hat, worn à la Mephistopheles, completes his rig-out, barring his 'butes,' and boots they are, something like small cradles for size and pattern, and as inartistic as an ironing box.

'But the wind's gone down a bit. What say you to a row across the Broad?' 
The wind has so far spent itself (Jim Trett said he thought it would ease when the tide ceased flowing) that we can with safety venture out. A few strokes, and we turn a bend in the river, then up a reed-fringed lane of water, and we are on the open Broad. The surface is still agitated, though it matters not much to the grebes yonder, diving and disporting in the cool waters. They find it quiet below; and the small roach, crowding into the deep holes in the more sheltered

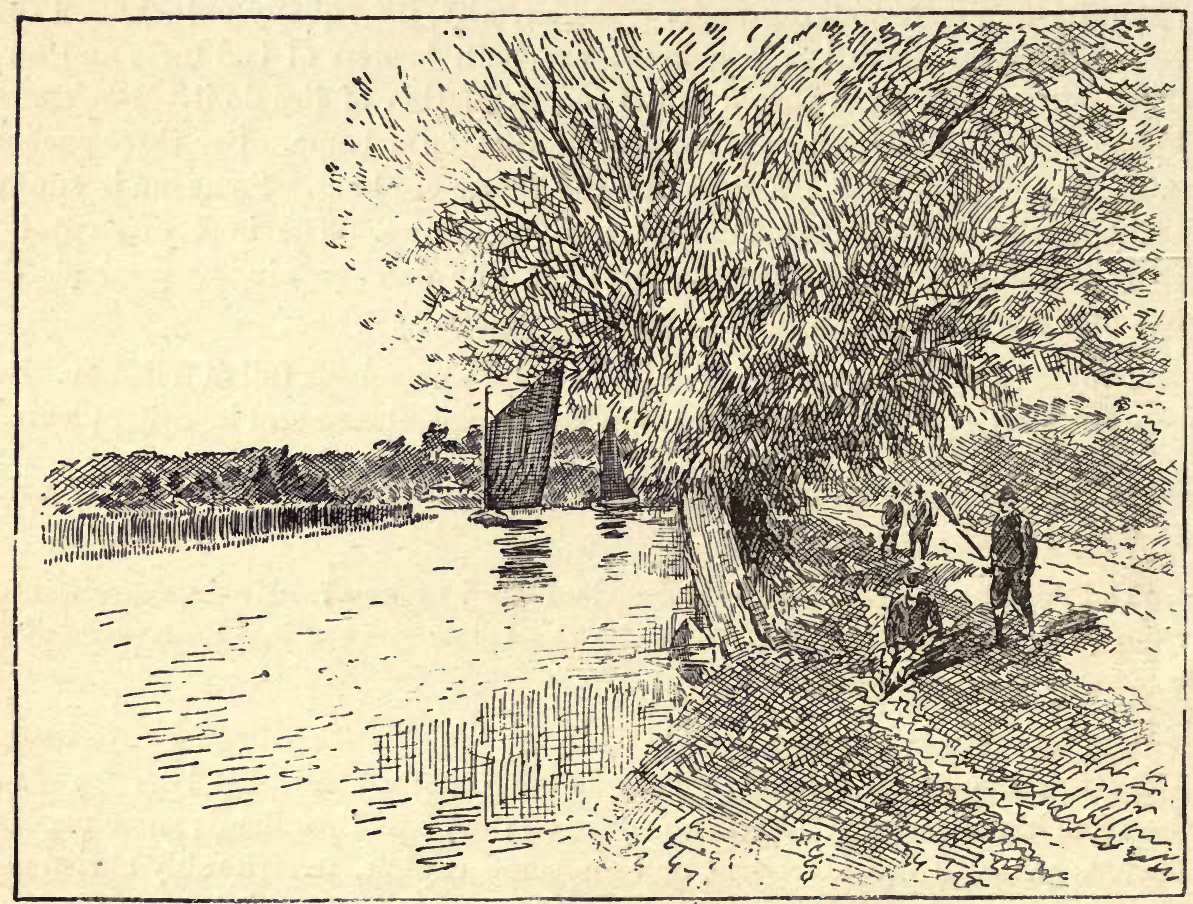

THE SILENT HIGHWAY.

'bight,' fall an easy prey to the sharp-billed creatures. We row along under the lee of a reed-bed, in which the clicking of the coots makes strange music; a parcel of reed-pheasants (bearded-tits) fly off from some woolly reed-tufts, and still more larks pass overhead. The froth, churned by the wind from the troubled waters, drifts in amongst the floating leaves that are entangled among the reedstems. A turn in the clump brings us into the teeth of the wind, and veritable 'white horsemen' splash over the boat's bows and wet our belongings. We soon tire of this, 
and make for a rond that is made gay by the blue flowers of the Michaelmas daisy, and fastening the boat, pick our way across the squashy bog, disturbing two or three snipe as we follow a foot-track that winds its sinuous way across to a higher level. This circuitous, swampy footpath has been worn by Jim Trett's 'highlows,' and trends towards the good man's domicile. It must not be thought that we have kept silence, for our friend is irrepressible.

'Now for a rare treat in the way of food for mind and body,' says he, 'for you'll get both at the fenman's cottage.'

The wind has lulled considerably now, and streaks of blue intersect the hitherto dull monotony of cloudland; the rain has held off wonderfully; nothing more than the merest sprinkling has fallen. We sit down awhile to muse and gossip, our friend still unreeling his inexhaustible store of Broadland folk-lore.

It is early when we enter the fenman's cottage. The old lady gives us a hearty welcome. Mr. Talkative nudges us and whispers that 'the 'old gal' is an original,'

'Why, Mr. Thingummy, I ain't seed ye for never, I ain't ! how's all yer fam'ly?' queries she, as she clasps his fat, freckled hand in her own wrinkled biceps.

' Sit ye down a bit, tea's jest riddy, and Jim 'll be in airly tu-day, 'specially as he knows yer cum. Why! here he cum-an' wha's the owd fule a golderin' (laughing) like that for?. Why, Jim, it du fare (seem) funny for yow tu hain (lift) yer eyebrows like a big grinnin' mawther (girl). Yow ain't so sadla, 'bor, I kin see, as yow wor when yer went out. Wha's up wi' ye?'

'Wal, old woman, I jest now seed narber (neighbour) Cubitt a comin' hoam with his owd dickey (donkey). Jest as they reached Loper Grey's it got skeered, and began a-dancin'; wal, off cum a wheel, an' a tub of swill, as he'd gone an' fetched, flew off along with him-down went dickey and tub an' Cubitt into a holl (dry ditch) togither. What with dumplin' and grease an' sich like, wal, bor, in all yar born days niver did ye see sich a sight, neither fore nor arter!' And the old fellow roars again at the very recollection of it. folk!'

'Take note of the words!' says Mr. Talkative, 'for they're rale Broad Nor-

It is a pleasant time that we spend over the good folk's tea-table. Jim Trett, having oiled his gun and hung it up, and his frail-basket of game, the aforesaid curlew and lapwing, to which has been added a mallard, and having made himself presentable, sits down beside us. Need we detail the savoury viands presented? 
Good tasty heron, hot potatoes, mushrooms from the marshes, garden beet from the cultivated patch surrounding, boiled pike and potted eel, and a 'whopper' of a blackberry pie to finish with. What more need we say of them? Jim Trett brings forth from his memory-locker many a stirring adventure, for there are such to be met with in Broadland, much that is interesting about fish and bird and animal, about shooting swans and snaring pike, ferreting and trapping, and what not! Several pages in the 'folk-lore diary' are scribbled full, as the good man plies his yarn, whilst the old lady keeps dropping her knitting upon her lap to listen, for, long after our appetites are satisfied does the chat continue.

Behold us, just in time at the Broadland Station-but for 'narber' Cubitt's ' dickey, we might have missed our train. The wheel had been replaced, the vagrant litch-pin readjusted, and both Cubitt and the trap had undergone a sousing. And couldn't that little 'dickey' spin along !

\%

$\Leftrightarrow$

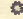

a

Next day's flood-tide finds us leaving our boat-house at the entrance of far-famed Breydon. Our craft is a characteristic Norfolk punt, our business-the slaughtering of the innocents; but not so much that, perhaps, as observation. October ushers in the great migratorial movement of the birds. All our summerbirds have reached warmer lands by the second week of it; their places have been filled by the hardier races from the more hostile north. Snowbuntings, twites, larks, wax wings, and a host of other land-birds, most as common, and many rarer, usurp our woodlands, meadows, and wastelands where the cuckoo, wheatear, chiffchaff, and others dwelt in summer-time; our mud-flats and sandy sea-shores resound with the varied cries of wading birds, and the estuary waters are lively with the wild fowl that float upon them. We cannot enter into this interesting subject, for a volume alone would cover it.

'The 'flats' will soon be covered. Great 'grey' gulls and immature, of the blackheaded species, with a sprinkling of others, winnow their way to and fro, snatching up fragments of fish and grease floating on the surface of the brown waters. Yonder stalks a grey heron-small flounders and juvenile shorecrabs suit him just as well as the frogs and roach of fresher waters.

Much might be said of the gradual change which has been creeping over Breydon during half-a-century. In the early part of it a number of men gained a fairly remunerative living by shooting the teal and widgeon and pochards that 
used to crowd here; many a rare bird, too, like the spoonbill, avocet, black-tailed godwit, and others fell to their guns. These, with black terns, phalaropes, and other rarities, and crowds of the commoner curlews, bartailed godwits, knots, and grey-plovers-these last three in their striking nuptial plumage-dropped in in springtime on their way north, and again in autumn, after the duties of procreation had ended. What hauls, before the 'close seasons' were instituted, did the hardy wild-fowlers make at times! But great changes have taken place in their onetime favourite habitats. And now October finds us with fewer birds to shoot, or look at.

As we drift and paddle up-stream, the calls of a few curlews, ringed plovers, dunlins, and mayhap, of some less common species, ring out over the rippling = waste of waters.

A short way ahead of us, upon the shelving mud, are half-a-dozen small grey birds. They are about as large as doves. Give us the glasses. What pretty little fellows! they are knots. What are they doing? Two are splashing thigh deep in the shallow, washing their already spotlessly clean plumage. The others are nimbly running here and there in search of red ragworms, or any small unfortunate crustacean that may have been playing in a tiny puddle. Now they all ' bunch up, run a short way again, then turn, and innocently eye us, as we come within gunshot. A strange weeting cry of alarm escapes one; but, as if still willing to trust us, they remain motionless. Shall we fire now? No! let the poor things go, why should we harm them ? We remain looking down the barrel of our redoubtable old eight-bore. We do not hesitate long. A mallard comes whizzing past, but we 'draw bead' upon him, and his fall headlong into the water follows the report. We can eat him. Such are the tender mercies of the wild-fowler. 


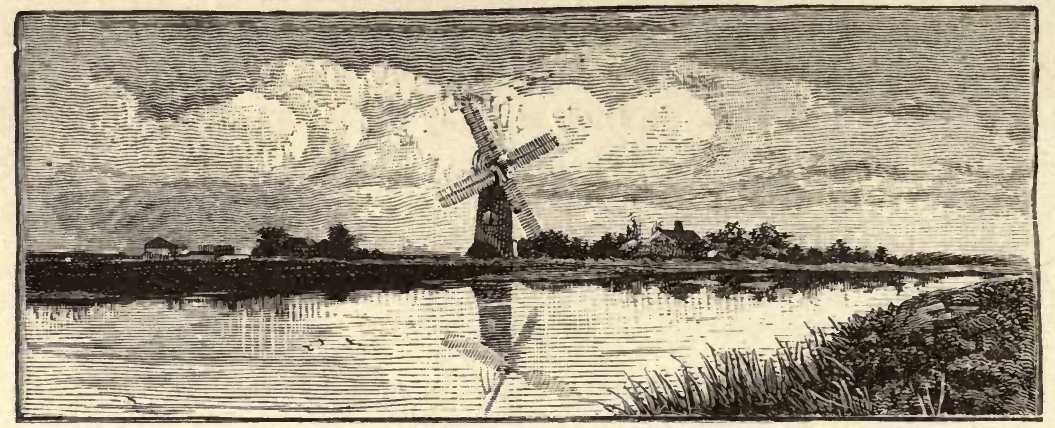

A MISTY MORNING.

\section{NOVEMBER IN BROADLAND.}

'Buy my caller herrin'! Ye little ken their worth, Wha'll buy my caller herrin'? Oh ye may call them vulgar farin';

Wives and mithers, maist despairin',

Ca' them lives o' men.'-Lady Nairn.

COLD, damp drizzle generally ushers in the dreariest of the Broadland months--November. It is the month of fogs and mists; and

'Driving sleets deform the day.'

Jim Trett, the fenman's, opinion would be that 'Nowember's neither heer nor theer-nor one thing nor th' 'tother-a kind o' dade an' alive affair!' The last remnants of the sere and withered leaves are stripped from the branches of the woodland trees, and they lie, a natural matting, to protect the tender shoots of a future generation of wild plants which love to spread their flowers in the glade and on the hedgebank. Flora is not dead, but taking needful repose.

Intervals of pleasant weather occasionally brighten the face of Nature, and the sunlight flings the shadows of the trees distinctly upon the land, and we are tempted forth to lengthy rambles. Such a morning finds us in the train which 'fusses' along through Broadland. There is scarcely a breath of wind, and the rays of the morning sun are dazzling after days of storm and mist and gloom. 
'Ah! 'bor-' volunteers a son of old Ocean who has made himself comfortable in his rough and ready fashion in the same compartment as ourselves, and between whose knees dangles a string of silvery herrings - 'This here's only a waatherbreeder, yow jist see if I ain't far out from bein' right. Goodness knows we've had a tidy spell o' bad waather this month. Law! how that blowed the airly part of last week!' After having delivered kimself of this comment he relapses awhile into silence; some unpleasant rcminiscences, mayhap, are passing before his mental vision. We refrain from unduly intruding upon his cogitations, and peering out from the carriage window we catch a glimpse of the sea, now placidly rippling and gleaming as if

'-in its summer play

As gentle as a child.'

Great gulls, mostly 'greys' (the immature of the greater saddlebacks), amongst which may be distinguished a few of their blacker-backed elders, and several herringgulls, and their smaller relatives, the Larus ridibundus, are winnowing their way on easy pinions to and fro, playfully dipping to the surface of the water to snatch up fragments of herrings and other animal refuse as their keen eyes espy them. Over the nearer marrum-covered sand-hills several white-winged snowbuntings are hunting for seeds of the various ' dune' plants that flourished there in the warmer days. In flight they are exceedingly conspicuous. And the grey-mantled hooded crow-recently arrived from the Norwegian fjords-loafs here and there, ready to pounce upon wounded fowl or any carrion that less foul-feeding creatures have passed carelessly by. We might, perhaps, have noticed the various changes in the country through which we are being rapidly borne along, but our brawny-shouldered, guernsey-clad fisher friend, who has distributed one or two characteristic expectorations upon the floor, and replenished his capacious cheeks with a fresh section of ' twist,' becomes talkative, and monopolises our attentions. Nothing loth, we settle to a friendly gossip, and let him spin his yarn.

'Yow are right, 'bor, we hev had some rummy waather, and only this time last week I never reckoned on comin' home tu my old gal ag'in. Boy an' man, I ha' followed the sea off an' on this twenty yeer, but I ain't had sich a neer 'un afore. I doan't like the sea a sight, and doan't know anyone as du; if they say they du - they lie; theer, 'bor, tha's straight. Anyhow, I mane them as go a-fishin' an' smackin' on the North Sea. It'll du middlin' in summer, but it cuts up rough in winter; an', little or much, it's rough pretty gin'rally. Us Broadland folkmany on us, yer know, ha' tu eke out a livin' partly ashore an' partly afloat; loads (many) foller it up altogither, spendin' a few odd days ashore between times. I 

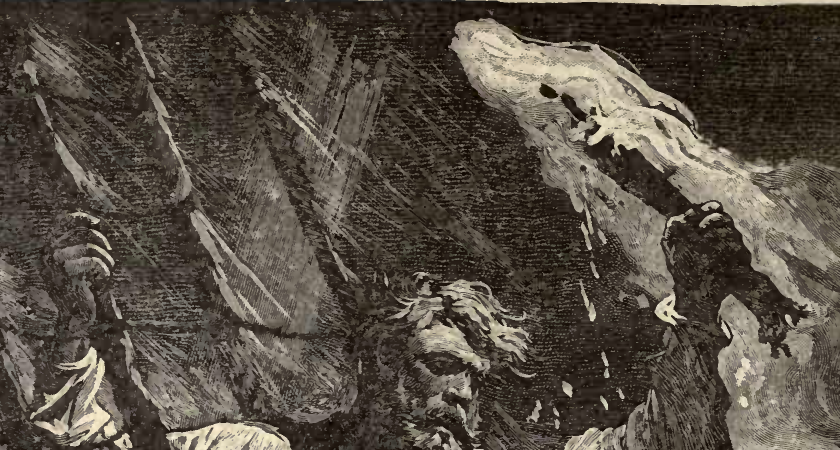

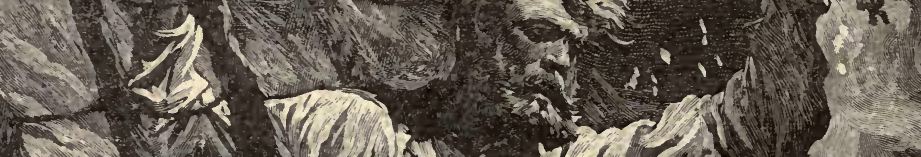
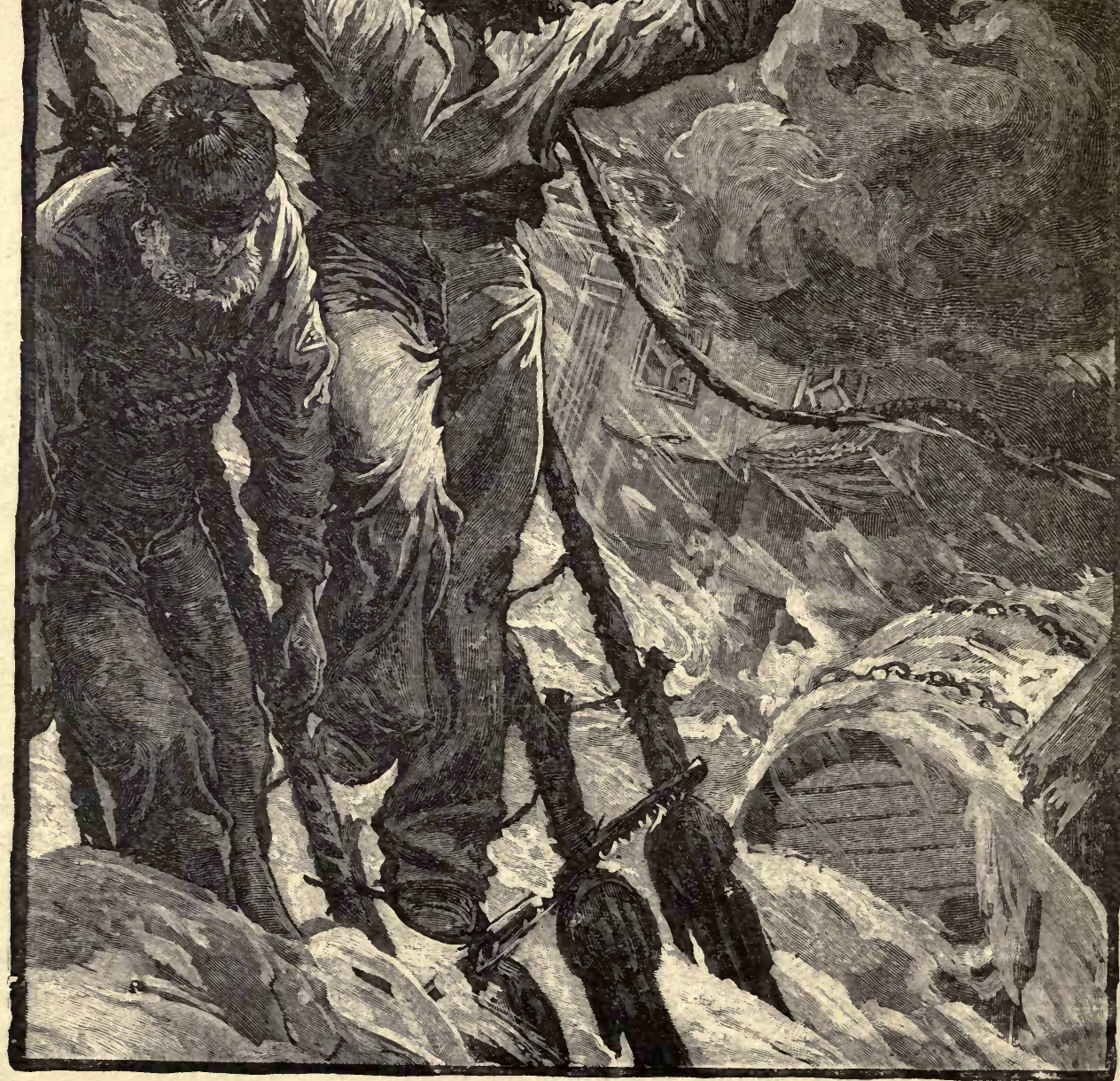

THE WESSEL WOR PRETTY WELL CLEAN SWEPT.' 
go a herrin' catchin', and spend the rest of the yeer ashore a farm-labourin'. The fisherman's life, 'bor, is a hard 'un, and it ain't the weak 'uns as kin stand it; them as kin doan't look any the wuss, but a sight the better arter leavin' the plough-tail awhile, and on the summat better livin'-for the briny piles up yer appetite as well --grow fat and kedgey (sprightly).

'I wor a-sayin' it blowed. Wal, the wind wor fair, an' things looked promisin' when the old tug Gleaner chucked off the tow-rope of the Sea-merv, and we stood out t' sea. We was makin' for the fishin' grounds some miles tu the Nor'east'ard. The sun went down in a ugly sky, but we didn't think as how things 'ud change for the wuss so quickly. We'd hardly got the nets 'shot,' and got turned in, when the-wind began to freshen. The skipper didn't like the manner on it, and his glass went back most cur'ously; he gan the order tu haul 'em in. Now tain't no easy job tu haul in a mile an' a quarter of herrin' nets, stowin' the 'bowls' (floats) an' sich like, especially when yew're doin' it in a hurry. It wor well we did it kedgey, for it blowed most awful by the time we'd done it, and got hove-tu under storm-canvas. Yow'd be surprised how sune the North Sea turns up choppy. We didn't feel pertikerler unaisy as the good wessel dipped her bows an' then rid over the towerin' seas. Now she clomb (climbed) the white-fringed mountains, and now she fell from theer tops intu the yawnin' gulf below. It wor more awful than grand plungin' along in the black night. Two on us kept watch: the night was fearful long. Thinks I, a basin o' hot tea 'ud du my innerds good. Half drownded with the spray as flung itself aboard, and stung an' blinded with the hail, I shouts into my mate's ear, and tells him so; an' went down. I'd hardly got below when we heerd a terrific 'row' on deck; a sea broke over the wessel enough to bust her in tew. An' we heerd a shriek. It wor poor Dick Stevens's last cry; in a moment he must ha' bin carried overboard an' bin drownded. I kin heer that screech now! Poor Dick! he wor a dacent fellow. Right intu the mainsail the water poured, heavin' the Sea-mew down on tu her beam-ends, and snappin' the boom like a piece o' stick. We thought it wor all up with us now, 'bor. The fore-sheet wor carried away, an' the sail flapped madly in the wind. Somehow, God only knows how, she righted. But the water had rushed down the hatchway an' half filled her. Did we feel skeered? Wal, if I say we didn't, it 'ud be a lie, but we didn't feel like givin' it up while the wessel hung togither. We should ha' looked a rum crew, if yow'd a seen us, some half-dressed, hatless an' buteless, jest as we'd turned in. We'd our work cut out, I kin tell ye. Cuttin' the boom clear for fear it 'ud knock a hole in us, an' clearin' away the mainsail, we rigged up a jib-an' sune brought her head tu wind. Some got tu the pumps, and right glad we was tu heer them shout, 
'There she sucks!' for how cud she face the heavy seas with her hold more'an half full o' water?

'Tired and jaded, some on us went below agin, steadyin' ourselves as best we could as the wessel plunged an' lurched-some on us prayin' tu Him whose only Son settled the gale on the Sea o' Galilee, an' axin' Him tu bless the wives and little 'uns as was worryin' at home for dad a-tossin' on the ocean.' (The hard horny hand brushes away a tear from the good fellow's weather-beaten cheek).

'A awful crash on deck agin made us hurry up the companion-way, an' a terrible sight met our eyes. Many a ton o' water had struck us. The wessel wor pretty well clean swept, boat an' everything gone barrin' the mast an' the rag of a sail ; and some 0 ' the bulwarks for'ard was knocked clean away. Well for old Billy Harden as he'd lashed hisself tu the tiller, or he'd a-gone with 'em. As it wor, he'd broke a rib or tew, an' we had tu carry 'im below. I took the tiller, prayin' God tu help me tu du it, while some hurried tu set another jibsail. We kept burnin' flares, but law! who cud help us? iveryone else had enough tu du tu look after theerselves.

'An' then, good Hivins! a wuss crash follered! We'd been run intu by another craft as wor in wuss plight 'an ourselves. It wor the affair of a moment, when a young feller, God only knows how he managed it, jumped clean off her intu ours. Afore we cud git on our feet agin - for we was all knocked down by the collisionwe lost sight o' her. She must ha' sank directly. The poor chap said as she wor the Persewerance, trawler, waterlogged, and in a sinkin' state, all hands had bin swept overboard except him, and the mate who'd steered for us. Poor fellar! the mate had gone down with her. We wor now in wusser state than iver: for we'd a big hole stove in the bows as let in any amount o' water, and it wor only by keepin' the pumps agoin' we floated. Fortunately the storm lulled a bit, and we ranafore the wind till we sighted Caister. Burnin' flares agin, we sune had the lifeboat arter us, and them brave Caister men, God bless 'em! took us off, puttin' as many o' theer own men aboard as cud be spared, and standin' by her, reachin' Yarm'uth harbour with us- with the wust o' the gale over, and the daylight a-breaking east'ard. Yow know now what mischief wor done, and how many a brave feller niver sailed intu port agin.'

By the time our friend's yarn is ended, we have drawn up at the Broadland Station. And as our road lies in the selfsame direction, we continue to chat in a friendly sort of way until we reach his cottage, standing in a well-kept little garden. Evidently he had been expected home, for a trio of merry youngsters, flinging 
wide open the somewhat rickety gate, ran to meet him, clustering round him as only loving children would, and smothering his bronzed face with kisses.

'Dad's home!' brings out the good man's wife, who meets and welcomes him as one of the "wives and mithers maist despairin"' only could.
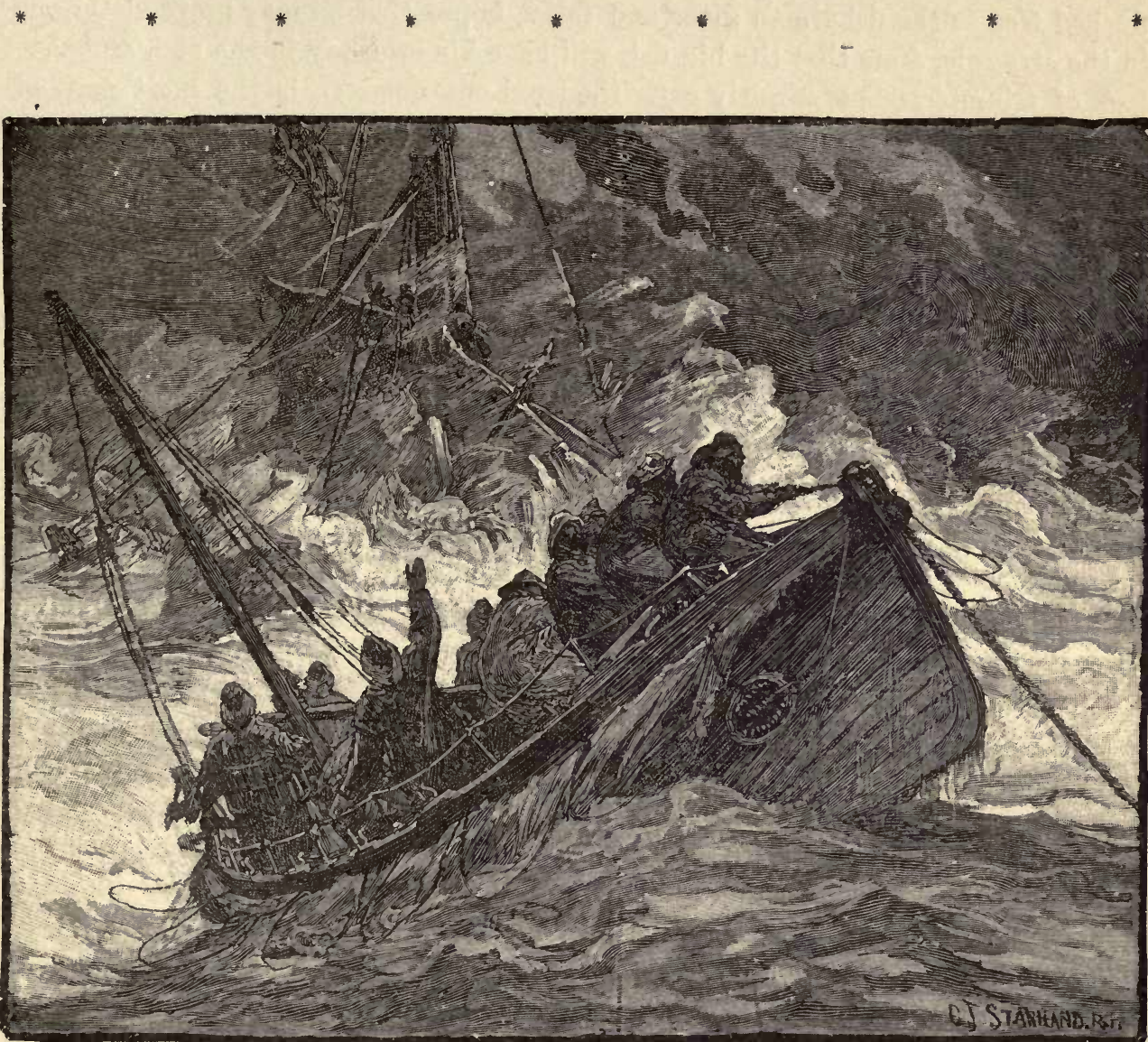

LIFEBOAT TRYING TO APPROACH THE WRECK.

What a marked difference there is in the outlook on the Broads to-day! The yachtsman has entirely deserted them, and but for one or two boats containing couples of enthusiastic pike-fishers, we should have the solitudes to ourselves. It 
is cold work at its best, sitting or standing hour after hour, throwing your live bait into likely spots where Esox lucius may be lurking. One need possess an abnormally strong constitution, and will beside, to follow it up successfully. One angler yonder has a big fellow in hand. How the maddened creature flurries and dashes in his terror. Eagerness and many another emotion are indexed on that flushed face as the fisherman gives and takes, hopes that he may prove victorious in the struggle, fears that the big fish will have his own way in the end, and that look of triumph, as he adroitly gaffs the tired-out monster, is the most marked feature of them all. And it is with justifiable pride he contemplates his huge quarry now lying at his feet, and blesses the stout, stubborn tackle, and his right 'good luck,' which proved more than a match for the shark of our Broadland waters.

A slight breeze ruffles the face of the cold-looking waters, and rustles through the rush and reedy broad-margins, fluttering the dry leaves and rattling the equally dry stems into strange rustling music. The reeds have not so much altered in general appearance yet as in colour. A few of the lanceolate leaves have dropped, and the feathery head-tufts have assumed the woolliness that tells of a full age and a speedy dissolution. On yonder tuft a couple of small brown birds are busily feeding. The juvenile molluses, which, in the sunny days crawled up their stems for a short siesta, have gone below, and the handsome bearded tits, for such are they, must perforce be thankful for a vegetarian dietary, and so they are taking their fill of reed-seeds. They are merry creatures-lively and musical even in winter, making the reed-bed ring with their clear, flute-like ping, ping. Unfortunately for the reed pheasant, as the Norfolkese call him, the collector is always eager for a specimen of this indigenous bird of Broadland, who but for persecution and slaughter, would remain with us all the year round. If our fenmen should exterminate the native race, it will become lost to us, for we have no migrants of this species putting in an appearance in winter. The time is gone for fifties to be seen together here.

What a host of birds we miss to-day! Not a reed-warbler, swallow, martin, or whitethroat is seen. The rattling notes of the common wren, hunting in the alders, and the chinking song of the redbreast have become familiar, and the harsher cries of the berry-feeding Turdidoe-of which the fieldfare and redwing are the most vociferous representatives, are heard on every side where hedgerows trend. There are some wildfowl on the Broad; they are apparently napping, for their heads are snugly tucked under wing. Their small size unmistakeably decides them to be teal. A crested grebe, disporting and fishing near by, disturbs them; 
they rearrange their already tidy plumage, then playfully dodging each other for a moment, take to wing, and make for some other Broad. The grebes do not appear so plentiful as they have been: on the approach of frost, when the skaters will make their advent here, they will have betaken themselves to the tidal estuaries, where food may yet be had.

What big bird could it be that, disturbed by our oar crackling in among the dry reeds, now took to wing, and with a sharp harsh cry hurried away? We recognise in its brown mottled plumage, and long, thick-ruffed neck, that rare East Anglian outlaw, the common bittern, now, alas! no longer deserving its distinctive title, for by the draining of its native reed-swamps and marshes, to which it resorted in the breeding-season, they no longer afford it that secrecy and protection which seemed so necessary to its perfect happiness. Jim Trett, or any of his kindred, would have been delighted to have made so close an acquaintance with the bird as we have, and to have levelled their fowling-pieces at it. 'Bottlebump,' as the fenmen name it, usually feeds at night, and is extremely loth to take to wing by day, suspiciously eyeing intruders through the labyrinth of reeds, and skulking off noiselessly at their approach. We have been fortunate in seeing the fellow in his dull, flagging kind of flight. There are few small creatures that fly, swim, or crawl that 'bottlebump' despises when downright hungry. The last eggs of the bittern found in Broadland were taken in the sixties. We catch, of course, an occasional glimpse of coots and moorhens, and pay scant heed to them, or the snipe which frequently pass squeaking overhead. Some tufted ducks, a couple of interesting shovellers, and a redthroated diver, seeking a change diet of young roach, severally engage our attention.

We push the boat up into a little sluice, at the end of which a kind of dam has been banked up. A rather large ditch on the other side is kept within bounds by a quaint, skeleton-like drainage pump-mill that throws its superfluous water into the Broad. We step ashore on the boggy soil, and scramble up to take a closer inspection of the curious structure. Its machinery is simple: the mill-sails when at work whirl round as the winds play on them. By a simple crank adjustment the 'box' goes up and down, now fast, now slow, as the rod is affected by the movement of the sails. They are revolving but slowly now, and for want of oil strange rasping and screeching noises emanate from the machinery. In the water below it the aquatic plants reflect their broken and dishevelled remnants; the sedges are crumpled and drooping, not a little red or blue dot of a wild flower is there to relieve the dull monotony of coloration-everything is brown and sere; the only bright colours are the yellow willow-leaves floating upon the surface. 
The slight breeze gradually dies away; the mill-sails cease revolving. Stepping into the boat again lunch is brought to daylight, and we sit down awhile to enjoy it. Quietude has reassured whatever creatures may have skulked into safe hiding at our approach. How unobservedly they vanish! A dark brown bird, wonderfully like the dead herbage that it skulks amongst, glides into notice. But for its movements we had not discerned it. It is a water-rail. Its sneaking habits are its safeguard. And what fuss or ostentation is necessary when life's duties and necessities simply consist of capturing the snails, slugs, worms, and aquatic plants on which it feeds? Its summer cry is a very odd croaking, which the natives here call 'sharming.'

A crackling in the reeds attracts our attention on the right. A huge animal, that we at once know to be an otter, forces his way through the reedy phalanx and is about to discuss the good qualities of a fine tench upon the very 'rond' we have just stepped off. His quick black eyes have caught our slightest movement, and like a stone he drops into the water. We secure that tench, for it's as good for man as otter, and the fellow can procure another far easier than we can. This savours of appropriativeness. Poor fellow! it's a sorry life he leads at the best, for every man's hand is against him. Nobody has a word to say in his favour; the very fish he devours are grudged him, as if he were to be blamed for taking the paltry fish for his living. Why not rather blame those who, for the sake of slaughter only, haul out hundred-weights to lie and rot upon the Broadside? However, while the interminable reed-bed exists, so long will the otter, in spite of persecution, at least hold his own.

Who can that be standing by the pump-mill, with an eel-pick in his hand, and beckoning us? At first we fail to recognise him, but his voice is unmistakeable-it's none other than Jim Trett, the fenman. We row back again; he has been eel-picking, and his inverted bucket, with a bottom where the top is usually located, with his pick, and his old fowling-peice, with his worthy self are soon aboard with us. We have divined his wish to row back home with us, and so to save his old legs some mile or two's tramping. He has flung a brace of wild ducks and a woodcock in before him. But why this alteration in his physiognomy?

'Wal, 'bor, as yow seem cur'ous about it, I may as well tell yer the manein' of it all. Last Tewsday, no, 'bor, let me be right on it-it wor the Monday, I went out with my old 8-bore, thinkin' tu git a clip at a bunch of grey lag-geese as wor scoffin' (eating) the young wheat in a field up hinder (yonder) tu theer hart's content. ' Now, old woman,'I says, afore laving the house, 'yow'll have summat worth 
the bakin' for dinner tu-morrer, or my name ain't what it are.' Says she, 'Doan't yow tell (count) yer chickens afore yer hatch 'em.' Tha's whare I bate yer, I says, 'cos they're geese an' not chickens at all!

'Howsomdever, I goes arter 'em, and by dint of crawlin' along a holl (dry ditch) among nettles an' brambles, wadin', through sluss (mire), and what not, cum up within aisy gun-shot. ' Now, Peggy,' says I, ' du yer duty!' and I claps her to my shoulder an' pulls the trigger. Only a click she made-I hadn't put a patch (cap) on. And if yow b'lieve me, I fumbled in ivery pocket an' cuddn't find one. The geese hains up theer heads a-wonderin', but seein' nought to be skeered on went on feedin'. I cud ha' hulled (thrown) Peggy in the holl. Howsomever, thinks I, I ha' got a match; here goes. So puttin' my hand jest under the trigger-guard tu steady her, I poured a charge of powder over the nipple so as not tu miss goin' off if possible. Click! went the match, up jumped the flock, or tried tu. As they bunched up, Peggy blazed intu 'em, settlin' how many I didn't know, for the powder as wor on the gun an' spilled in my hand, bust up intu my silly old face, burnin' off ivery hair as wor on it an' fairly blindin' me. But I got my bards-four on 'em, as sun as I cum anyway round at all. Ane ain't I a lovely critter jest now? My old woman wor finely skeered. I hope I shall get over the 'mute' (moult) by springtime.'

As we row across the Broad, a dense fog, which we have been anticipating, settles over everywhere, so that to steer homewards without mishap we skirt the reed-bed, making a detour much longer than necessary, but, as in walking in a fog, so one may row and row and find oneself an hour hence at the very place started from. Now and again a gull looms up in the thickness, appearing much larger than he really is; like a grebe or two that we make closer acquaintance with than usual, he shuns our society as soon as he recognises us. As the fog seems likely to last some time, we quit the Broad and walk homewards with our discursive friend, who has much to tell us. This afternoon he is expected at Farmer Hobbs's with his ferrets; rats have become more plentiful than welcome. One curious incident happens near the landing-stage. A moorhen paddling round in search of food has attracted the hungry eyes of a big pike. A splash and a whirl! and the fish's ugly head appears above water, but a moment too late, for the bird has taken to wing in the very nick of time.

$\circ \quad 0$

0

$0 \quad 0$

$\circ, \quad \circ$

0

0

0

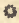

On our way towards the village we pass a trio of farm-hands watering their horses at the horsepond. They have been at the plough. We cannot help noticing 
the contrast in the gait of Hodge, whose life is entirely spent ashore. Long used to walking over ploughed and soft land, he takes slow and lengthy lopes (strides), with his shoulders forward and his awkward arms swinging in pendulum motion at

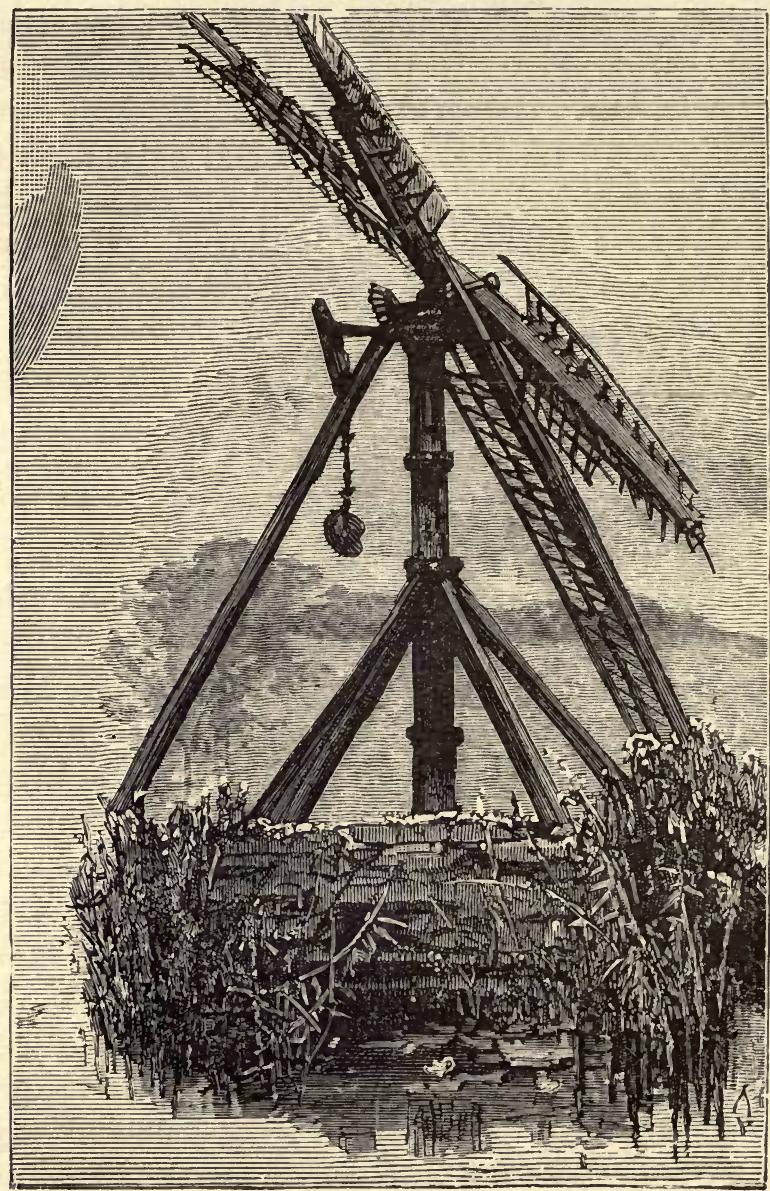

A DRAINAGE PUMP.

his side. His billycock hat, canvas slop, and fustian breeks, tied with pieces of string below the knees, complete his orthodox attire. We venture to ask one brawny fellow ' why these knee-cords?' 
' 'Bor,' says he, 'yow foller the plough, or work on the land where wet grass an' rubbidge sod (soak) yer trowsers below, jest yow stoop without 'em being tied to, and yow'd bust off ivery button yow'd on 'em. It gi'e yer freedom o' movement, 'bor, and law! we doan't fale dressed without 'em.'

The fisher-broadman takes shorter strides, rolls in his walk, turns out his elbows, and somewhat reverses his hands. His well-filled guernsey, and heavy, but less ungainly boots, with the usual billycock, completes his undress uniform. The barber and he are on friendly terms, for a moustache he resolutely refuses to wear. He becomes altogether smarter in appearance, manners, and lingo, than droning, vegetating Hodge. But those brawny, rotund shoulders and that portly figure mark the fisherman indelibly - not that all grow fat.

?

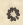

s

o

$\circ$

$\circ$

6

Having accepted an invitation to 'Hev a cup o' tea' in our fisher friend's house, we drop in on our homeward way to the village station betimes, finding the good man playing all sorts of capers with the youngsters, who at times threaten to 'swamp' him, as he puts it. The appearance of strangers curbs their rough play somewhat, and without being rude exactly, and a long way from being impudent, they stare at us as we enter. And they do stare, to be sure, these Broadland children, although the novelty of ' yachtin' and other folk a gadwaddickin' (tripping) on the Broads is wearing off.

There is a savoury smell of bloaters-not those oak-billet smoked delicacies from the fish-house, but fresh herrings-or rather the least bit salted, that have hung a day or so in the air to dry and season. Grilled over a clear wood fire, they are exceedingly appetising: and we are not long in 'falling to.'

The home-made bread is in keeping with the herrings, which we disintegrate with our fingers; the fastidious spoil the flavour by using knife and fork. 'Hunches' of bread disappear as if by magic all round-the youngsters as well as we have prodigious appetites. Seven herrings disappear from between Billy Tungate, our host's big brown fingers; he, too, has an appetite. The tea is black by name and appearance; Tungate's 'Missus' has been broken into 'bilin' it in the old kettle, and emptyin' the leaves only when theer's no rume to put more in.' Then when full, as the fisher-folk do at sea, she empties it, so he tells us, and makes a fresh start from the kettle bottom.

One Broadland cottage is much like another both inside and out. There is 
the same old-time red-brick structure, tinged with the greens and yellows of age. The same honeysuckle or roses trained over the small-paned window, and the martin's nest above the doorway. A tiny flower-garden runs before it to the palings, with a hedge of holly or privet growing parallel. The walls inside are whitewashed, and a regiment of little cheap prints and family photographs are hung in anything but a methodical way upon them. They have been tacked on as they turned up. The brick floor is sanded, the fire-place bright with lead and elbow grease. Everything is clean as wax, from the youngsters' ruddy faces, fresh-washed for ' dad' to kiss them, to the baby's little print dress, for 'Dad's home, yew know !'

The homely repast having come to an end, friend Tungate gets down his long clay pipe, draws from unknown 'fob'-depths his sealskin pouch of strong cheap shag, and tempts us to share its contents. The youngsters have each had their hug and kiss, and their mother trots them off to bed-but not to slumber yet, for they have some arrears of fun to get over before they fall asleep, when not a 'deen' (sound) will be heard, not even a 'winnock' (cry) from the baby. Our good man grows chatty as the smoke curls upwards. We may not place on record scarcely one fraction of his yarn, which is of things fishy and of the sea.

'That in-shorin' of the herrin's is a wonderful thing, 'bor,' so reg'lar, so enormous-and in course, so welcome. Some say they cum tu spawn; p'raps they du, but I hev a notion as they cum on the hunt for food as well. What du herrin's eat? Wal, they eat wery small shrimps - 'possum shrimps-I heerd a gent once call 'em, small sea-wermin, and even the spawn an' young of theer own sort. It's a rare God-send-theer cumin'. We fishin' chaps muster up some thousands strong an' man some four or five hundred boats. A fishin' boat, all found, without her nets, costs suffin' over a thousand pounds, and her nets nearly 'arf as much. So it manes some thousands o' pounds a-rollin', doan't it?

' Yow know, at least I s'pose yer du, that a herrin' net's like a wall of meshes, floated a-top with corks, kept straight down with its own weight. A single boat drifts out some hundred an' fifty nets, each thirty yards long, 'leven yards deepsome mile an' a 'arf that makes. it. We keep an eye on the gulls an' wil-ducks (guillemots) an' the gants (gannets); where they fish we know theer's suffin'. Shutin' (shooting) our nets at nightfall we hauls them airly in the mornin'. It's a rare sight tu see us haulin' in thousands of silv'ry critters as hev 'gilled' theerselves a-shovin' tu get clear o' the nets. The more they shove, in course the tighter they get, an' drown theerselves, they du, tu be sure. We got over twenty last a couple o' nights ago, that's, lemme see, how many? A last is ten thousand; reckin' 
thirty-tew over for every hundred, that's thirteen thousand tew hundred. I reckened it up this mornin' at tew hundred an' sixty-four thousand! they fetched $£ 9$ a last; that warn't a bad bit of work. Gales an' bad luck play the mischief up with us sometimes.

'We git paid in proportion to our takes, yer know. So much on the last, or

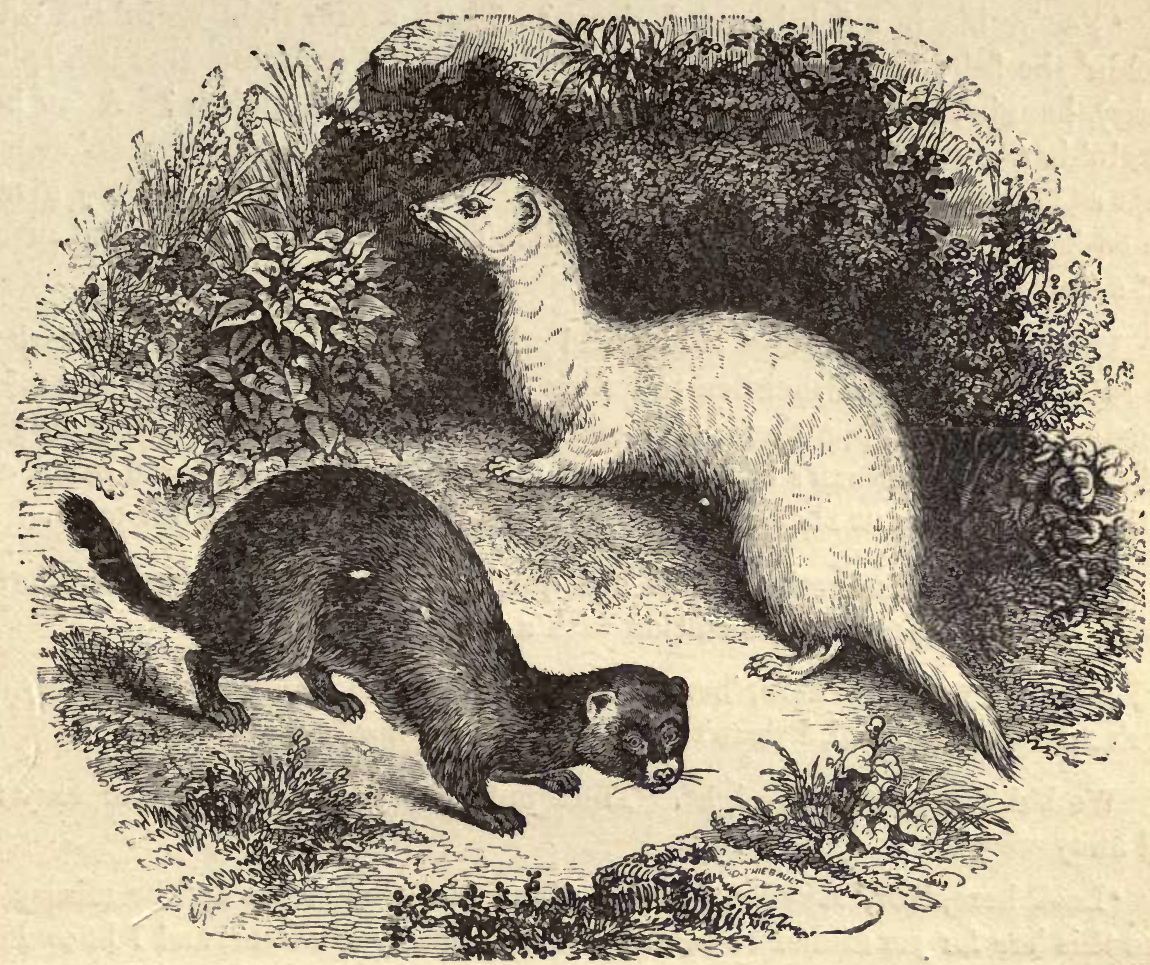

JIM TRETT'S FERRETS.

otherwise by the 'dole' (share). Theer's 'leven on us from skipper to boy. A good season; and some may have tu take $£ 40$ or $£ 50$ for their share, which ain't bad, seein' as we fish from the end of July tu Christmas. Bad luck it is as spiles us when we 'make up' in debt! It's a lottery, 'bor, it are.

- Yew've seen the Fishwharf, ain't yew, when the fishin's in full swing? Ain't it a sight tu see the fleet of boats put in an' out, and the full herrin' swills (baskets) 
spread a hull (whole) mile along the quayside? An' ain't we a rough, unkempt lot in our sou's an' ileys (oilskins), and faces unwashed for a week at a time? Jist fancy a little herrin' rulin' the lives of thousands !-merchants, fishermen, tellers (counters), auctioneers, cupers (coopers), blacksmiths, sailmakers, ship carpenters, and a hundred other sort of folks, and thousands of 'em all gettin' more or less benefited by one little fish-but, in course, the millions of 'em du it.

'Yew've bin in a fish-house, I s'pose? That's a rum sight seein' the carters fetchin' the fish; the hands a saltin', washin', spittin' (running them on spits or sticks), hangin', kipperin', packin', labellin,' an' what not, ain't it? A few hours hangin' in the smoke-rume makes a herrin' intu a Yarmith blowter ; an' as many weeks as hours make ham-cured reds of 'em. And for a breakfast dainty give me one on 'em, though for a matter of that, didn't they make me dry, I cud manage half-a-dozen. Ha! Ha!-'

Much that relates to the habits and whims of the herrings, their varieties, the manœuvres of the fishermen to outwit them, much of the birds and marine monsters that prey upon them, of humorous and pathetic incidents that brighten and sadden the fisherman's life, is told us, until the striking of the old Dutch clock in the corner warns us that it is time to be off if we would catch our train.

A tap at the window brings us out quickly. It is none other than our old friend Trett, who is off to the station with a trunk of eels.

'I thowt as yow'd be here, 'bor, an' as I've borrered Caleb Hewitt's pony-an' heer's rume for yer, wal, I doan't see as how yow'll need tu walk.'

We bid Tungate good-night. Trett puts the grey pony into an easy trot, and away we go.

'Look here, 'bor,' says he, 'yow've allers bin good tu me an' the missus-du take this 'ere for yer dinner tu-morrer. It'll plaase yer missus, and I know it will yow. I kilt a couple this mornin' down in the seven-acre midder (meadow).'

We dine at home next day on a fine fat bean-goose, and wish, dear reader, you could have dropped in upon us and have had a taste of its sweet juicy flesh. 


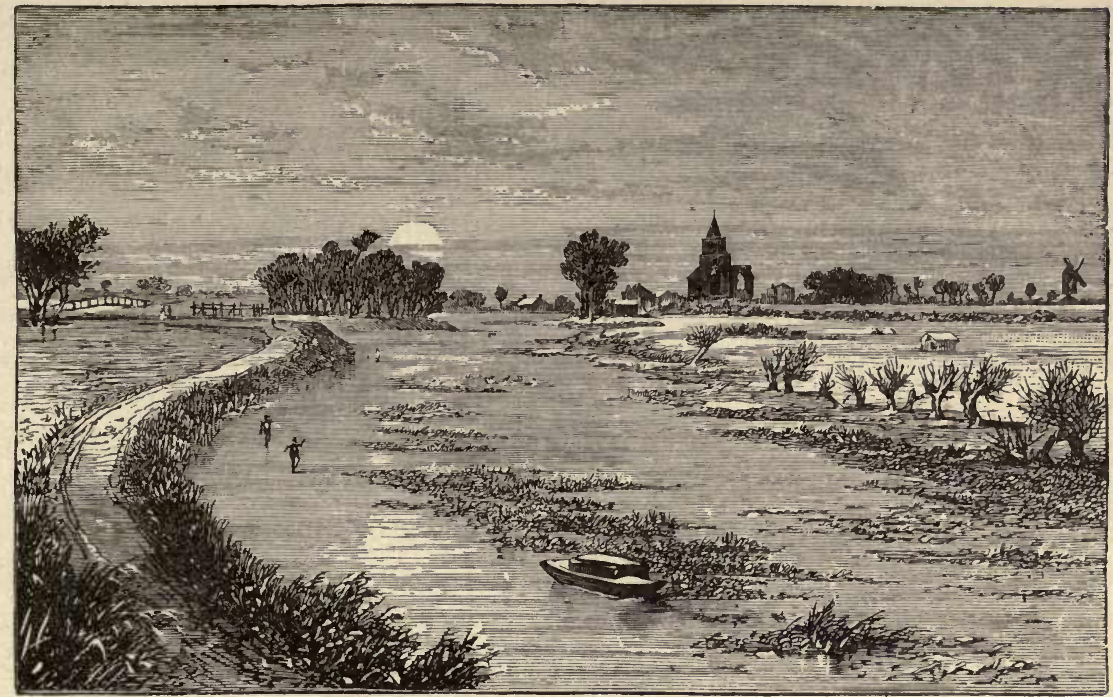

A WINTER SUNSET.

\section{DECEMBER IN BROADLAND.}

'Oh winter! ruler of th' inverted year,

Thy scattered hair with sleet-like ashes filled-

- $\circ$ o

I love thee, all unlovely as thou seem'st, And dreaded as thou art.'

-Thomson.

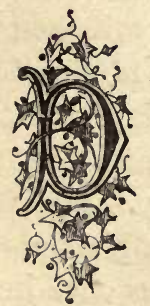

ECEMBER, on the whole, is not a pleasant month. It is generally ushered in with clouds and vapours; and stormy days are not infrequent. Now and again towards its close 'the hoar frost is scattered like ashes,' or a mantle of snow covers the landscape with whiteness. On Broadland there is an apparent cessation from outdoor labour; the farmer has finished ploughing, but the feeding and housing of his cattle demand attention; whilst Hodge 'jobs about,' as he expresses it, for there is corn to be thrashed in the open weather, and grain to be carted. He will tell 
you that 'it 'oant du, 'bor, tu fowld yer arms, an' not tu keep a duin' summatan' maaster's wery good that way, in findin' jobs for tu du.'

Our old fenman-friend finds scant idle time, except when the waters are hard 'friz'; reed-cutting commences now; there's hedging and ditching to do, whilst up at the warren he finds it not unprofitable to help the warrener net rabbits for an adjacent market-town; and for this latter congenial adjunct his brace of ferrets comes in exceeding handy. He finds them useful, too, in clearing the farmers' premises of rats; not that he altogether exterminates them, nor would he wish to if he could, for ' winter'll cum round agin sum day, yer know, an' what's the ferrets for?' This admission Jem Trett would not venture to make to any but a trusty friend.

It is a dull, murky day, with the promise of a change - which cannot be for a much worse-that finds us turning our backs upon the quiet Broadland station. We saw little to interest us coming along. A number of white gulls; on most friendly terms with their opposites in colour, the rooks, were foraging on a freshploughed field, flocks of sober-tinted larks rose up on either side as we startled them into hurried flight. We might, perhaps, have observed more had we not become so absorbed in a gossip carried on by some substantial-looking countrywives who have been to town to purchase their Christmas groceries. It is simply astonishing how everyone knows everybody else's business in these quiet villageswe are treated to a sample of it; amongst other analyses, their intermarriages and family relationships are worked out in a genealogy as amusing as it is exhaustive.

None too pleasant is our walk Broadwards; the roads are veritable 'sloughs of despond,' and the unpleasant drizzle which has evolved from the thickening vapours, driven by the wind, filters through the leafless hedges as we plod along. We speedily overtake a miserable object, shambling along ahead of us, and forcing our conversation upon him, bit by bit draw from him the story of a misspent life and present destitution. He 'once ran well,' but the strong drink hindered him. It is the old story - a goodly start, pleasant prospects, success, temptation, yielding, gambling passions aroused, excessive indulgence, theft, exposure: then in quick succession followed hopelessness, carelessness, want, and misery. Could it be possible that the unhappy, rag-draped specimen of humanity rubbing shoulders against our own, glad of, but unprofiting by a word of sympathy, was once in affluent circumstances, and one whom the honourable at one time esteemed as one of them? We study his bleared physiognomy; thereon yet linger traces of refinement and education. We query as to his wandering in such an outlandish country. 


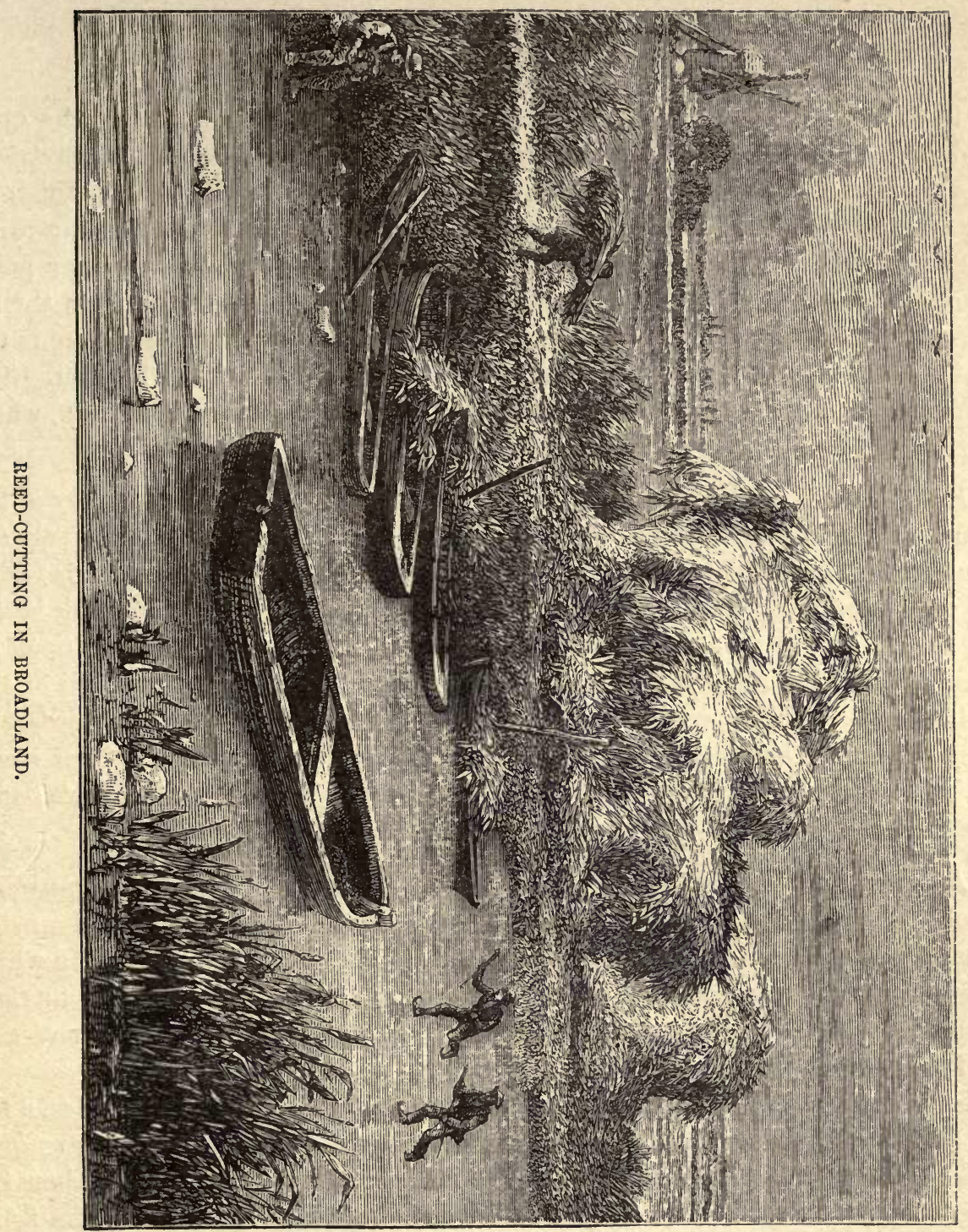


' Sir,' replies he, ' what matters it to wretched Cain whither he wanders, so long as no one knows him, so long as a crust is to be had for the asking, and a publichouse is looming in the distance?' Alas! for poor humanity.

It is not sufficiently tempting to-day for us to venture out upon the open Broad. The rain has ceased, and a streak of blue intervenes between the retreating rain-cloud and a darker one which follows. The wind still blusters, but from the way the tell-tale on yonder mill-cap whirls round, and strange, harsh, grating sounds proceed from part of the unoiled machinery, we notice it is veering a point or two more northward. A pelting hailstorm bursts upon us. How keen the air is becoming! Sleet begins to mix with the lessening hailstones, and there is the promise of snow in those mountainous clouds looming up from the horizon. The sun breaks out awhile, and tinges the whole scene with a warm ruddy hue, which is superseded by a colder yellow.

From a little brick Broadland bridge we are content to take our survey of the Broads. Here in their leisure moments in the finer days, and on Sundays between church times, the natives delight to ' mardle', resting their chins upon their folded arms on its parapets; and here they love to ruminate. We are not one whit better than they. Before us lies a Broad with a white-edged ripple dancing upon its surface as the wind beats down it, flinging the froth in amongst the stems of the bending reeds. The breeze for a moment lulls, and the yellow-brown reeds and rushes duplicate themselves in the depths. Decaying leaves and broken stems sprinkle the surface amongst them; the débris of the waterlilies, the mare's-tail, and many another broad-plant are rotting to form fresh soil below.

All around and about the Broad signs of the year's decadence are apparent. The old willow's slender twigs are bare, and the beeches' more distorted branches are as naked. Lichens are crowding the tree-trunks; only the fir-trees, in which the wood-pigeons now resort at eventide, bear the slightest resemblance to their summertime glories. We miss the songs of the woodland birds. The crek-rekrek of the moorhen is only heard at intervals, the scolding of the crested grebes we listen for in vain. Most of them have gone to the milder southern counties, a few may be found in winter in our open estuaries; to-day but one or two have ventured to show themselves here. They will be ready to visit salt-water when the Broad becomes clothed with an icy mantle. We do not discern even a pike-fisher to-day. The only individual in keeping with our surroundings is a fenman cutting reeds. We bring our glasses to bear upon him. A plank pushed over the bows of his flat reed-boat rests upon it and the stumps of those reeds already cut; 
they easily support his weight. The process is simple, yet requires some judgment. Holding a bunch in his 'dannocked' (gloved) left hand, he makes a slightly upward sweep with his sickle, cutting the reed-stems as near the surface of the water as possible. An axiom of the Broadman says, 'An inch o' reed below water's wuth tew above it.' That from under water, when dry, becomes harder and more durable than that which grew above. He lays them as cut athwart the boat until they form a little stack, then 'quants' with a shoving pole to the staith, where he ties them up in bundles some six feet in circumference, and sells them by the fathom. When reeds were more in demand than now, a reed-bed formed a profitable adjunct to the owner's property and the fenman's earnings. Pains used to be taken in propagating them; detatched pieces of a reed-bed were moored in likely places, and a new growth speedily began. Now they encroach upon the Broads all too fast, extending their area year by year.

The bridge we stand on spans a narrow run of water, and with the roadway trending on either side, separates these two particular Broads; the runlet unites them. Turning round we take a survey of the other. There is a sameness in the outlook; only a grey church-steeple breaks the distant line of trees, and a tiny red flag marks the mooring-place of a trading wherry. A swampy rond, with a narrow footpath insinuating itself into the labyrinth of alders, tempts us to follow its windings. The bog-moss is growing rankly, all else we tread on is dead and decaying. Water squeezes upwards at our every footstep, and brambles catch our sleeves with their sturdy thorns. The swamp is not untenanted. A snipe, and now another, take to zig-zag flight as we approach their hiding-places, and a longbilled bird, which we recognise at once as a woodcock, springs from under our very feet, flies wildly and in an indefinite manner overhead, and drops again as suddenly as he appeared.

Turning abruptly to follow a less-used pathway, we come suddenly upon a sight which fills us with interest and with sadness. Depending from a low treebranch by pieces of twine are the numerous victims of a gamekeeper's vengeance. Stoats and weasels form the greater number. We wonder not so much at this magpie-condemned to death with some degree of fairness, perhaps, for the mischief he was believed guilty of - that of egg-stealing-but why this innocent barn-owl? We reckon up this gamekeeper as an ignorant, unread, and unthinking fellow. Some of the stoats are mere skins and skeletons, for the blowfly was on his rambles when they were slaughtered, and the shot-holes thickly perforating their necks and shoulders are a guarantee of the accuracy of the keeper's aim. Some siskins are dodging about on an alder-stem, but take to flight on the approach 
of a green wood pecker, whose anticipations of an abundant meal, hiding behind the decaying bark upon a willowbole just beneath it, are not far out. We remain motionless; as yet the fine bird with his yellow-green coat and crimson cap has not espied us. At a snail's pace we bring the glasses to our eyes. How the fellow is chipping the bark to splinters! Now he has exposed

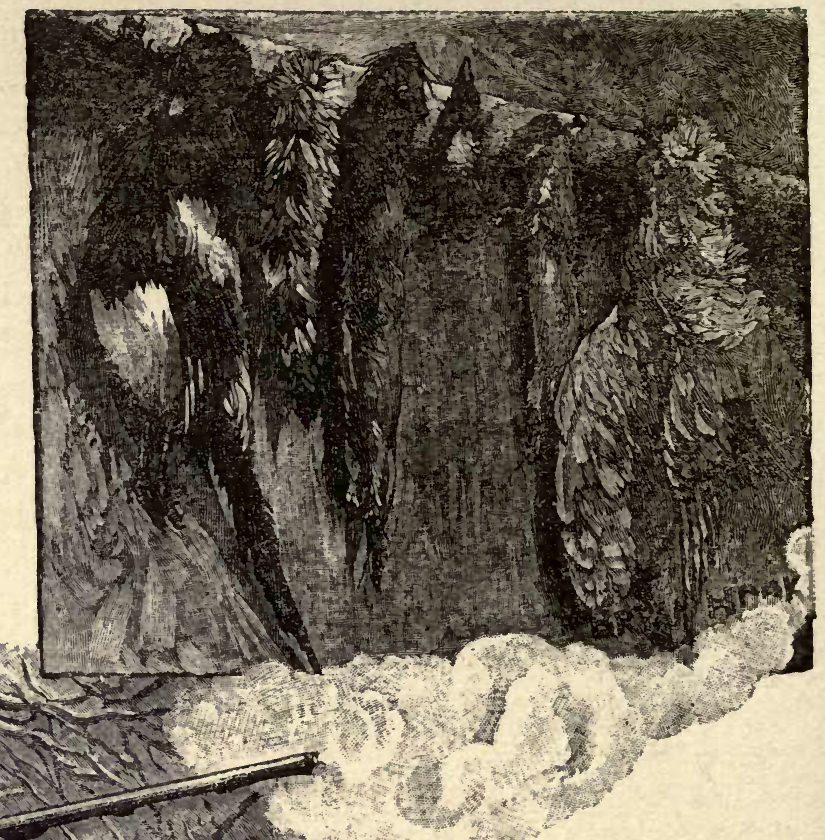

THE GAMEKEEPER AND HIS MUSEUM.

the trunk to view. It is a grand time he is having amongst the ' armadilloes' that, so unexpectedly brought to light, are too stupefied to seek fresh shelter.

We reach the small red drainage-pump. Its sails are not revolving. A strange noise, sounding very like the rushing of wind through the pump-sails we instinctively imagine as such, but an alarm cry, as of a plover, makes us as suddenly look up. It was not the wind, but the rustle of a hundred pairs of wings, and that cry was the wail of a golden plover. They are migrating. We observe no other 
birds except a dabchick disporting himself under an overhanging bank. The wind suddenly springs up and flings in airy circles the descending snowflakes. Ere we reach the village, the canopy of blackness which has been shutting out the blue above us is pouring forth its accumulation of snow. It eddies and twirls around us in the blast which whisks up the flakes already fallen, and drifts them under the hedgerows. The first that fell have melted, but the myriads following lie one upon the other, and remain until all Nature is covered with a pall of dazzling whiteness. The bell in the village steeple is tolling ominously. Surely Death has not been visiting Broadland? Alas! he bas, and 'the fair have fallen.' Dong-dong! at short intervals reverberates from the ivy-clad steeple as the old sexton, at measured periods, tolls the passing-bell. He has left his spare resting against a moss-grown headstone that marks the last resting-place where one of 'the rude forefathers of the hamlet sleeps.' Yawning beside this is a freshlydug grave into which the spotless snow is gently falling, as if to carpet the bare earth with unsullied purity. There is a stir in the village. Apron-clad matrons are quietly hurrying to see the last of a little maiden whose burial takes place today. Some have donned all the black in their possession as a mark of respect for the departed. They are making for the church-yard. In the distance a solemn procession is wending its way hither also. An old white pony is drawing its precious burden upon a cart. Over the coffin a velvet pall is spread. Snowflakes are falling lightly on it. Immediately behind follow the classmates of the dead maiden, each with a snowdrop and a sprig of southernwood in her hand, to throw directly upon the little coffin. Then follow the bereaved parents and their children, and the friends of the family - of whom muster a goodly number, for half the village has turned out to pay homage to the little one gone to the Land where there is no winter.

Scarce a word is spoken; and even then it is in subdued whispers. The parson meets them at the church door with due solemnity; and the procession files in slowly under the shelter of the old thatched roof, two or three old men, bent with age, and leaning upon their sturdy staves, bringing up the rear. Even they have a tiny slip of crape tied round the left arm.

The church service over, the coffin is borne out, and lowered into the open grave. There is a strange feeling of awe displayed upon every feature as the soil drops with a thud upon the coffin-lid, and the quivering lips of the white-headed parson pronounce the well-known sentence, 'Earth to earth.' Sobs are heard from relatives, and sturdy fellows, holding their broad-brimmed hats in one hand, brush 
away a tear with the other brawny biceps. Now a sweet song is trilled by children's voices as they stand around the resting place of their lost companion-

\section{'Brief life is here our portion, Brief sorrow, short-lived care; \\ The life that knows no ending, \\ The tearless life, is there.'}

By the time the song is ended, there is not a dry eye in the company around. Even rough 'Nixey' Lutkins the poacher, and his sworn enemy, the gamekeeper, drawn by one bond of sympathy, are now side by side looking over the low wall, and are in tears. For the time being old feuds are forgotten in the general sorrow. Poor little Nellie Goldstone was the only being who ever had a kind word for Nixey. Maybe she 'being dead, yet speaketh' to him. Who knows but that even now he may be making up his mind to profit by the lesson of her spotless life? The service finished and the last look taken, the congregation slowly disperses. And the sun peering out from behind the snow-cloud that has passed over, lights up the landscape, and makes the countryside beautiful-a fitting emblem of the brightness of a better world, after a journey through the valley of the shadow of death.

$\circ$

$\circ$

Winter now reigns supreme. Christmas, the jolliest season of all the year, is close upon us. The town is unusually busy, for everyone is making great preparations to welcome it. Even the hard-worked counterman puts up with its inconveniences, with rest and pleasure in prospect. There is an unusual bustle at the Broadland station as we step out of our carriage, and worm our way through a maze of hampers and baskets of good cheer. The feet of fowls and the tails of game peep out in all directions. Is it not strange that much of our pleasure should depend on the death of the humbler creatures?

Merrily ring the bells in the village steeple. Ding-dong-ding! It is a sorry peal, but the best the triplet of bells can do. Strong arms pull the ropes, and the sound of their clanging is heard afar. The drowsy bats among the rafters no doubt draw their heads from under their membranous wings, and wonder at their strange awakening; and the owls above them hiss, and crouch at the farthest corner of their location. Ding-dong-ding! let everyone be glad, for 'Unto us a Child is born, unto us a Son is given,' so runs the roughly-painted scrollwork some village artist has proudly tacked around the old oaken pulpit. There are lights 


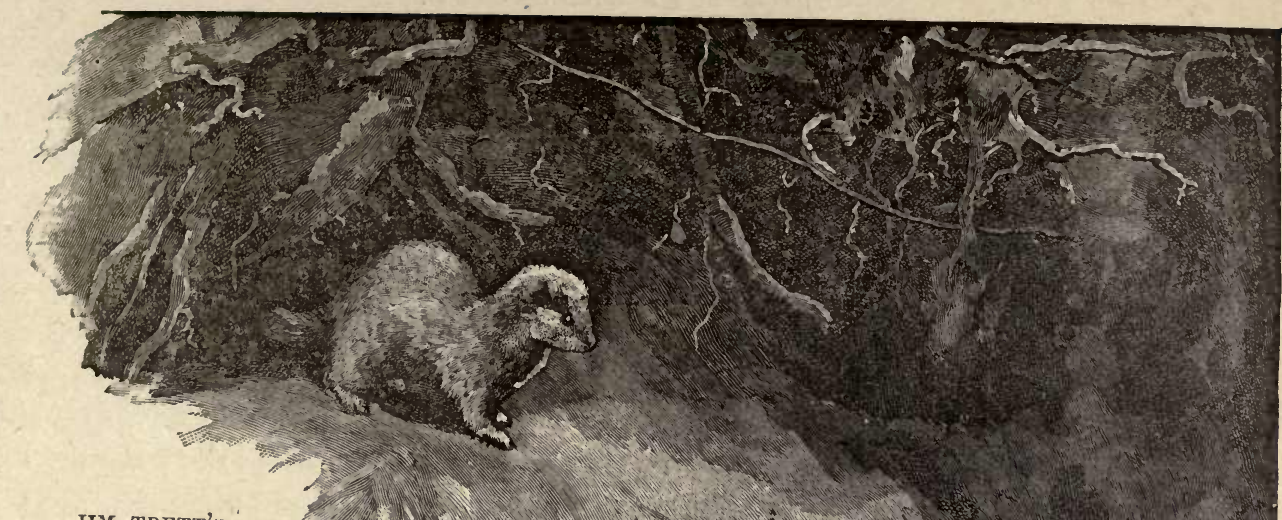

JIM TRETT'S

FERRET AT WORK.

twinkling in the church windows. The parson and his helpers are making the church bright with evergreens, befitting symbols of that Name which endures through the generations.

It is not to the church we wend our way; we are off to a supper at Farmer Kerrison's. A son is 'hoam from th' army, one of his married gals is down from Lunnen with her husband, and it's a right merry time he intends a-havin'.' And it is a 'right merry' party we find sitting down in the spacious kitchen to a table creaking beneath the weight of the good things of this life. Kerrison welcomes us heartily, and his company smile us a friendly greeting, he himself saying us a complimentary 'So you've come, 'bor!' We could say much about the coquetries and gallantries of the younger farm hands, and the curious bits of

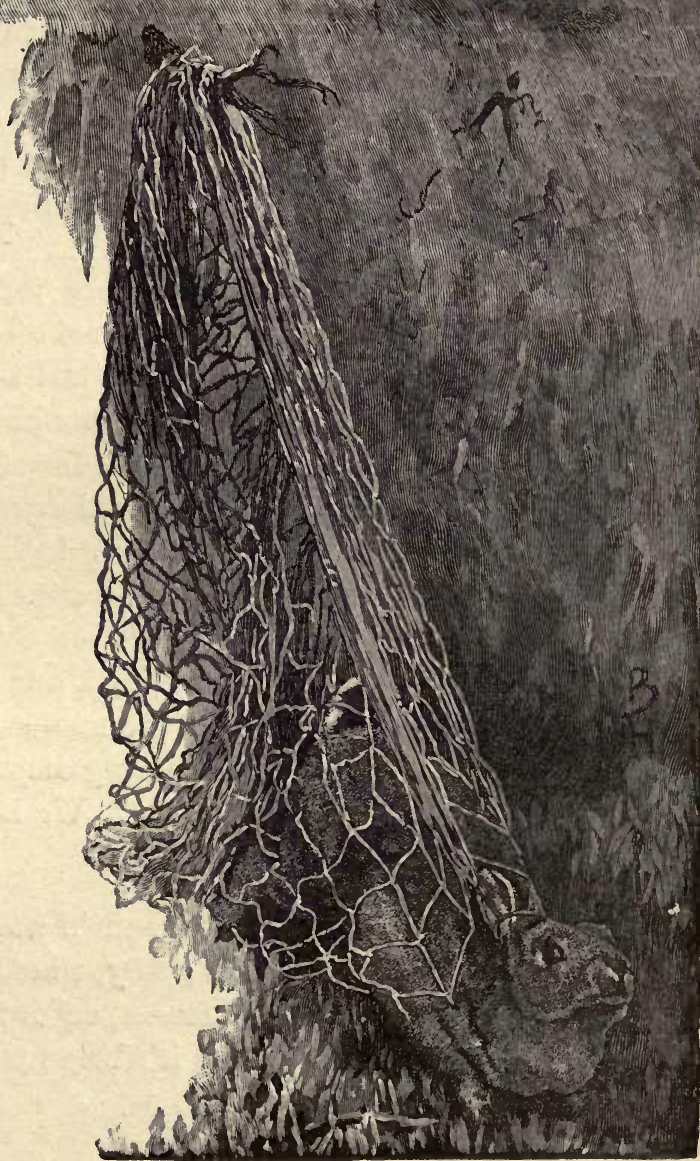


' broad Norfolk' dispensed by the older ones, but space forbids. When grace is said we 'fall to' with a gusto that bespeaks the quality of the spread and the appetites that will speedily devastate it. First come Norfolk Dumplings. We give them capitals, for they are unique. They are the simplest of puddings, compounded of flour, water, yeast, and a dash of salt, ' biled twenty minnetsnayther more nor less.' Only Norfolk matrons can make the legitimate article-to see them knead, and roll into shape between their hands, nip off or add a pinch of dough is a sight that impresses you. But to have them served up 'dun tu a nicety,' and swimming in gravy, is an episode in your existence. Our friends stow away one apiece, some of them more, and then fall to a loin of pork that would make a bilious man stand aghast. With it disappear turnips and potatoes. Next follows ' toad-in-the-hole'-pork sausages baked in batter. This fails to upset or satisfy. Then comes pork and apple-pie, with a crust as thick as a policeman's boot-sole; then pumpkin and apple-pie, and those who wish it may. have their turn at rice-pudding and giant custards. Lastly comes a monster plum-pudding, of which, strange to say, but sorry fragments afterwards find themselves upon the kitchen table. All this time there has been much uncorking of non-intoxicants, and the ale-barrel has been running itself dry as well.

We bid the party Good-night! ere the evening's fun commences, which finishes with a merry dance and light refreshments. Strolling along in the cold crisp air we wander Broadwards for the last time in the old year. The frost-dust sparkles in the moonlight. A slight rime has touched the tree-branches and the hedges with whiteness. The Broad is frozen over. We hear no sounds but the crackling of the ice, and the occasional cry of some awakened bird. Once we notice the murmur of starlings roosting in the reed-bed; then all is quiet again. The report of a gun rings through the clear night air. It is a suspicious sound, and we doubt not some poacher is out upon the prowl. Presently a figure emerges from a small wood ahead of us, but, as if our presence is simultaneously detected, it disappears again. Once again, the man as if reassured of our neutrality, steps out from a nearer thicket, and staring inquisitively at us, recognises us. It is Nixey Lutkins at his old game again. We had hoped better of him, and we venture to tell him so.

'Ah! 'bor, what's bred in the bone'll work itself out somewhere', he replies, 'a feller can't help his instincts; why, when I wor only a nipper the sound of a shot 'ud jest make me all excitement, an' it is only with a gun in my hands that I am happy now. In spite of all it's browt me, I can't part myself from it. And 
why shouldn't I have some fun in life jest as well as the rich 'uns? They abuse us for destroyin' a few head o' game-they can kill 'em by the hundred. What feeds theer bards but the farmer's corn?-an' he dussn't open his mouth tu say so! Theer bards! ha! ha! ain't them phaysents an' pa'tridges on one man's field tu-day, and on another's tu-morrow? Them as they belong tu, why doan't they mark 'em? Cud any on 'em sware tu a bard, and say as sich an' sich a one wor theer own pertikler property? If they're theers, says I, why doan't they keep 'em at home? - Wal, I may be wrong, but I like the fun an' excitement: the sight of a long-tailed 'un asleep on a tree-branch sets me all afire.

'All right, guv'ner, yow doan't need tu feel unaisy. Trew ! a man's known by the comp'ny he keeps; but Duke'll see as we shan't be overlooked. (He whistles, and a scraggy, but faithful lurcher, which has been till now in hiding, glides up to, and takes its place behind him.) Yow'll keep sentry, oan't yer, Duke? (The dog answers by lifting a paw and wagging its tail in a cautious manner.)

'Talk about dawgs-Duke's as knowingsome as most. He never sells hisself by barkin', he kin trace an' bring in a hare like a Christian; and he never reckernise me in comp'ny, an'll even pass me in the street as if we was the biggest strangers. 'Bor, he can tell mischief a-brewin' afore I can.

' $\mathrm{Ab}$, 'bor, I hev had some rare du's in my time. Let me light my pipe, and I tell yer of one or tew. I once made a good haul on yin island. It war thiswise, I know'd as how a lot of 'longtails' was roosting in theer at nights, for I'd seed 'em flyin' over at even-time. They was snug-like; theer wasn't no stoats, nor rats, or sich-like to worrit 'em. Law ! it wor tantalisin' tu see 'em whizzin' over the bit o' water, and turnin' in all serene. One night I watched the keeper off the beat, and slippin' my old gun where she now is (see, I've got her here-half in each pocket) I nips down to the Broad. Theer wasn't much mune (moon), but jest enough tu distinguish this from that. The Broad wor hard friz; an' snow lay thick. My fut-marks 'ud tell a tale, so I jest off wi' my butes an' stockin's an' rewerses 'em-. stocks outside, yer know; then I wraps some rushes round 'em. Yow wouldn't ha' known my tracks from a elliphant's. Theer they wor, snoozin' in the trees. I pops over a dozen right quick, and off I cum; I hops ashore, strike off across some fields, makin' most of my way across tangled places an' aside the holls, and makes for hoam ; I found old Cubitt's dickey wanderin' in a lane; on him I jumped, makin' him trot me the remainder of my jarney. Tu bustle him off with a kick or tew as he'll remember tu his dyin' day, tu hang my bards in the chimbley (chimney), pop intu bed, and get tu snorin' wor the work of a few minnets. An' 
none tu sune nayther, for I'd hardly dun it, afore I heerd the 'slop' (policeman) an' keepers cum in. In course upstairs they all stumped, where I wor a-snorin' like a hipperpotamus. Says the bobby, 'This 'ere is a rum du-Nixey's at home an' fast asleep-it worn't him !' ' 'Tis a rummen!' says a keeper, 'we doan't need tu wake 'im!' an' once more clappin' the bull's eye on tu me, they hooks it. Howiver

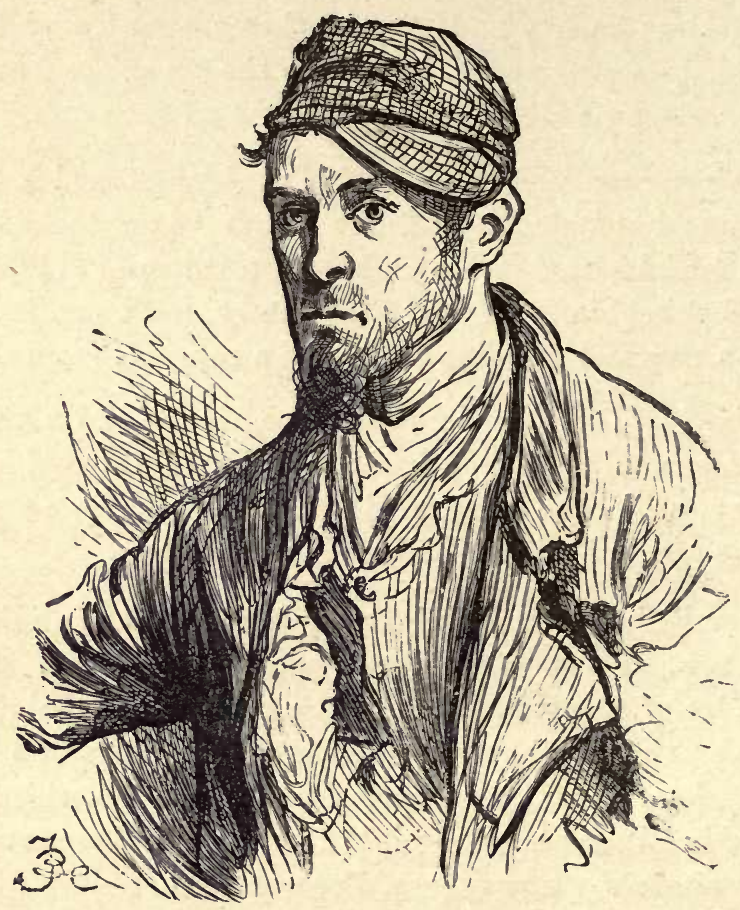

NIXEY LUTKINS.

tu keep from bustin' wi' larfin' I didn't know ; and they hadn't cleered the housedoor afore I busts.

' Hallo!' says one, 'wha's that?' and I suppose he listens. Then he says, 'I s'pose it's the cat awailin'.' Jest then the cat du trot downstairs, and that settles theer opinions. They couldn't prove nothin', but ' give a dawg a bad name an' hang 'im,' so they say!

'The wust o' wrong duin' is that one thing leads tu another. If a feller doan't 
lie outright tu hide his tricks, he ha' tu act full many a one tu screen 'em, and he's so tempted tu act mean as well. I ha' used false whiskers, makin' myself look like other folk, and once I slipped on a shepherd's coat. I wor traced, but got away; but poor owd Barney Hewitt got run in cos they know'd his coat! It wor only my ownin' up tu the poachin' as saved him a fortnight on the staircase, for they found a couple of pheasants in the pockets when I dropped it. Mind yer, I never showed fight, I walue my neck tew well. No ! if I'm copt (taken), I'm copt, if I ain't I get's away. Tha's logic, ain't it? Says I, never prop up a rotten beam with a wormeaten bit o' timber?

'Once I got away when I wor took. Duke an' I was out one evening on the old game. We'd got a hare-that wor afore hares wor chalked as wermin. We heerd footsteps, and with no more ado we draws ourselves intu a heap of rubbidge -hedge-clippin's, briers, brakes, and sich-like, and covered ourselves serene. That dawg didn't make a deen (sound). The keepers wor arter us. One on 'em actually stamped on Duke's fut as he passed by, but the old feller didn't even wince; I felt his breath cum quick an' sharp agin my face. They passed on. Sendin' Duke hoam, for I know'd they'd leave no stone upturned tu git me, I hides my old piece benean a heap of hay (she wor rusty enough when I fetched her agin!) and makes for the willage pub. They wor theer afore me. In a moment the slop (who'd bin called in tu help) had the snips (handcuffs) on me, and out I ha' tu go. They thought they'd got theer bard, but they hadn't. Handcuffed as I wor I bolted, they dashin' arter me. I cud run then, and for a while outdistanced 'em. Presently I trips agin a stone, and comes down whallop! Luck, however, wor on my side, for one o' the links wor broke. Law! how I pegged it! Wal, 'bor, they lost all traces of me. And by a roundabout way I gits intu a barn unbeknown tu 'em, and hides benean the straw. I'd a knife in my pocket, and by dint of sawin', by next nunetime had my hands free altogither. I got fearful hungry, but thowt it best tu hide till nightfall. Then I goes round a mile or so tu my brother's - he wor a hawker-an' put his brumes an' pails, and dwiles (housecloths) an' sitera in a box built behind-like. I begs him tu see me hoam. So, arter a feed, he pops me in hid fust (head first), and puttin' the pony in, off he trots. Law! that wor a ride if yer like; I had no ind of bunnies (lumps) on my hid when we got tu the house, once when the pony draws intu the hoss-pond I jest about stands upon it. I wondered what wor up! Arrived at the house he jerks open the door an' shoots me in like a bale o' goods. I wor laid up with a low fever for some weeks arter that; and in the meantime the affair blowed over.' 


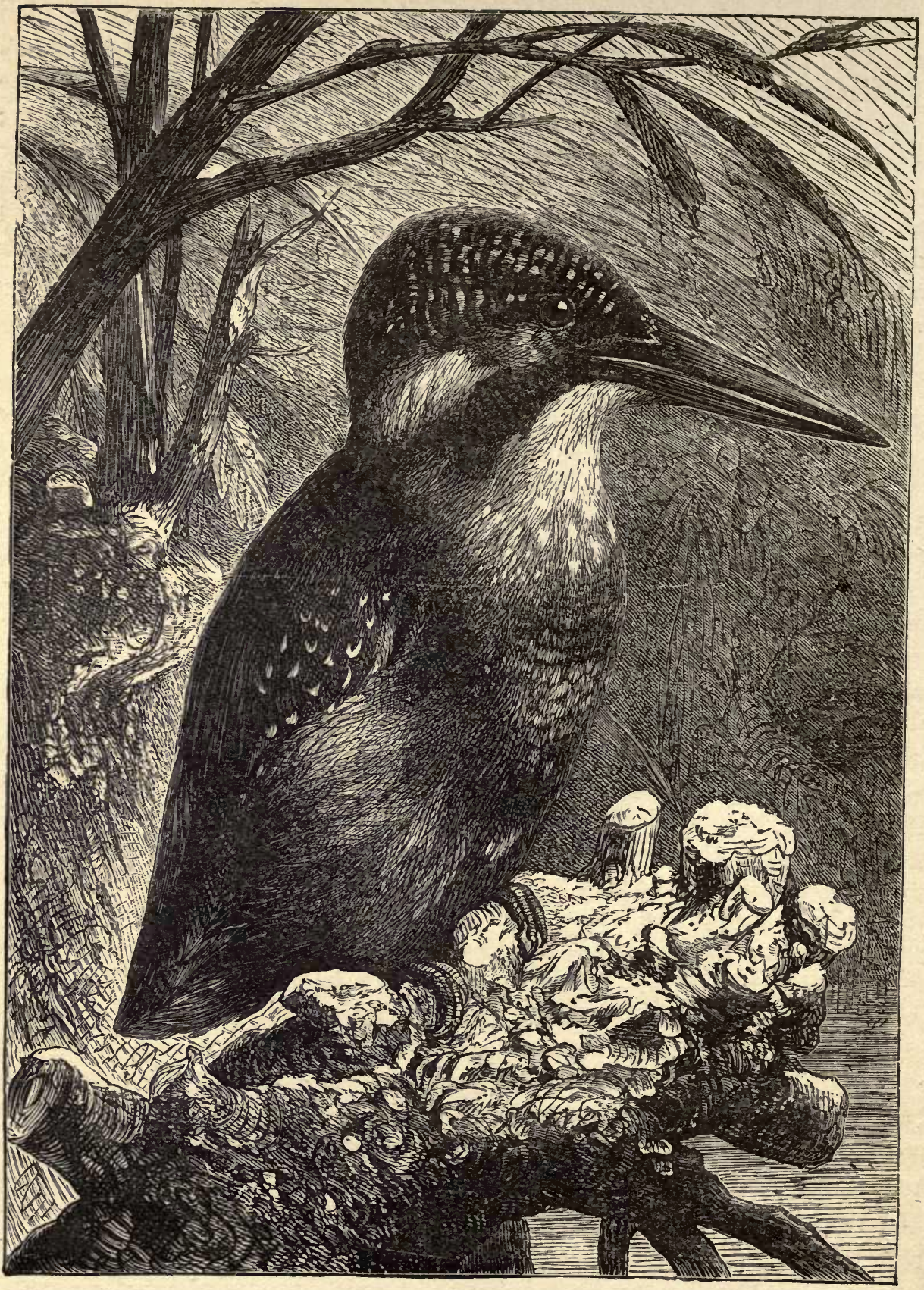


Just now Duke shows signs of uneasiness and his master takes the hint. But before he leaves us he hurriedly remarks that he really intends to drop the 'bisness-'bor,' he adds, 'that 'ere little 'un as wor buried 'tother day begged on me tu du diff'rent, and s'help me, sum day I mane tu; but it's hard tu give up the old ways. P'raps in the new yeer I'll turn over a new leaf, but I must ha' my Christmas dinner fust. Good-night, sir.'

The fellow as suddenly vanishes as he appeared. We continue our musings on the Bridge alone. The keeper, for he it is whose oncoming has put the poacher to flight, accosts us, and makes comment on the beauty of the night. Feelings of delicacy on his part forbid him interrogating us as to whether we'd heard or seen anything in his way.

Ding-dong ding again peal forth the village bells, their clear mellow tones ringing out through the bright quiet night. There is something weird and beautiful in their clanging, yet so strange withal. Now for a while they cease, and the music of sweet childish voices is borne along upon the breath of the gentle wind, a welcome as appropriate as it is touching, of the

\section{'—Day that we love best in the days of the year,'}

bringing to mind the beautiful and never-tiresome story of the nativity of Him whose praises the angels sang at Bethlehem. And His presence seems so real and near to us that unconsciously we take off our hat-and the place whereon we stand seems hallowed ground.

Reader, it is time for us to take leave of each other: can we do better than part at the manger where the Holy Child lay? Our. Broadland jaunts have come to an end. 




\section{DAY USE \\ RETURN TO DESK FROM WHICH BORROWED

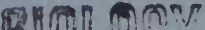

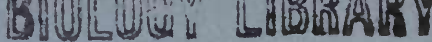

This book is due on the last date stamped below, or on the date to which renewed.

Renewed books are subject to immediate recall.

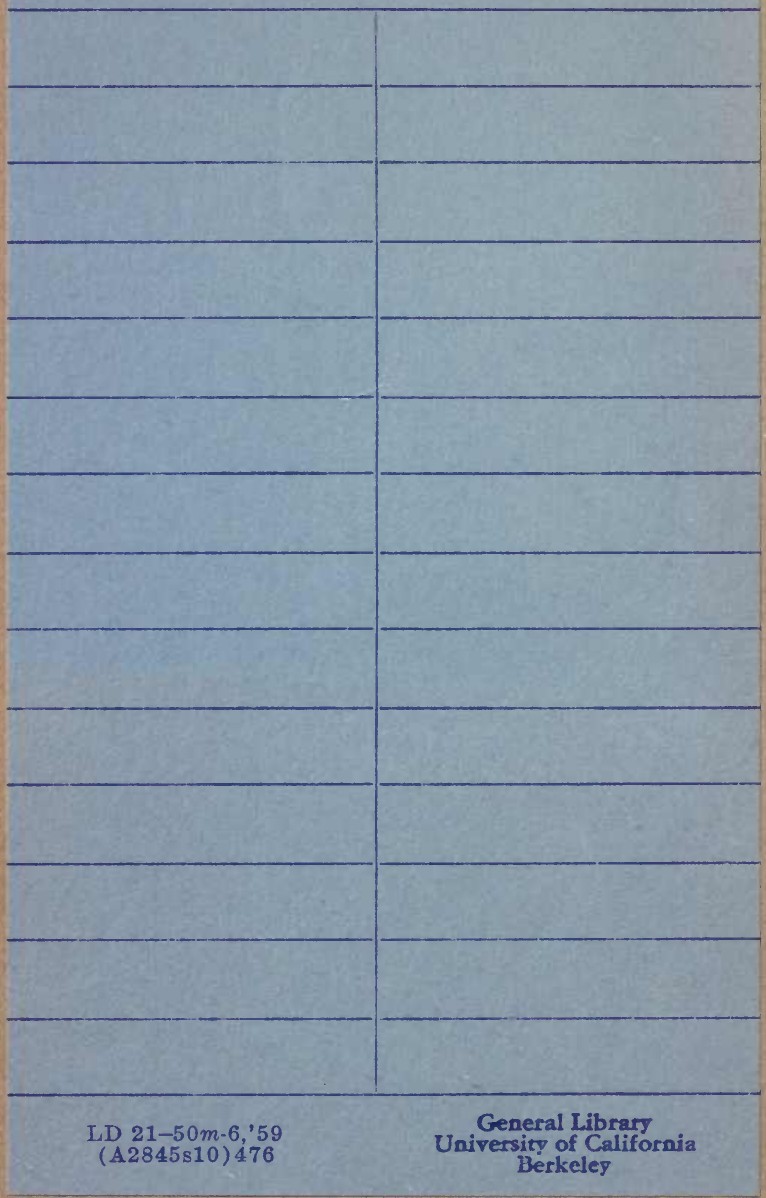




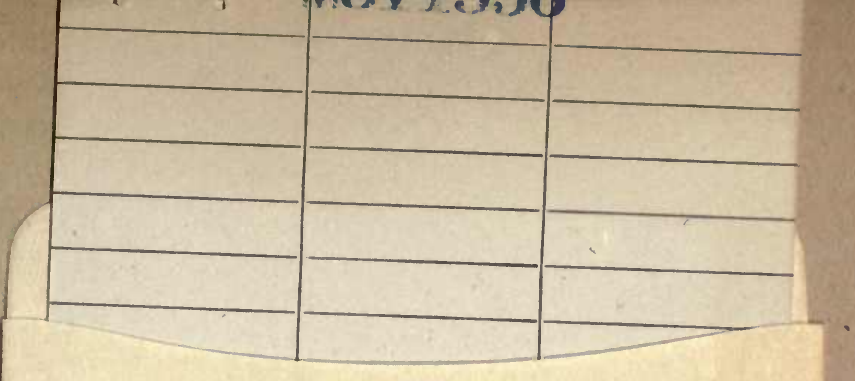

$\bar{M}: 311556$ 
